UNIVERSIDADE DE SÃO PAULO

FACULDADE DE FILOSOFIA, LETRAS E CIÊNCIAS HUMANAS

DEPARTAMENTO DE LINGUÍSTICA

PROGRAMA DE PÓS-GRADUAÇÃO EM SEMIÓTICA E LINGUÍSTICA GERAL

ALPHA CONDEIXA SIMONETTI

\title{
Palavra dramática: voz e tensividade
}

São Paulo

2011 
Alpha Condeixa Simonetti

\section{Palavra dramática: voz e tensividade}

Dissertação apresentada ao Departamento de Linguística da Faculdade de Filosofia, Letras e Ciências Humanas da Universidade de São Paulo para a obtenção do título de Mestre em Linguística.

Área de concentração: Semiótica e Linguística Geral.

Orientador: Prof. Dr. Luiz Augusto de Moraes Tatit

São Paulo

2011 


\section{Folha de aprovação}

\section{Nome: Alpha Condeixa Simonetti}

Título: Palavra dramática: voz e tensividade

Dissertação apresentada ao Departamento de Linguística da Faculdade de Filosofia, Letras e Ciências Humanas da Universidade de São Paulo para a obtenção do título de Mestre em Linguística.

Área de concentração: Semiótica e Linguística Geral.

Aprovado em:

Banca examinadora

Prof. Dr. Luiz Augusto de Moraes Tatit (Orientador)

Instituição: DL / USP

Assinatura:

Prof.(a) Dr.(a)

Instituição:

Assinatura:

Prof.(a) Dr.(a)

Instituição: Assinatura: 


\section{Agradecimentos}

Ao professor Luiz Tatit, pela confiança e pela orientação neste trabalho.

Aos professores Ivã Carlos Lopes e Waldir Beividas, pela contribuição para meu crescimento intelectual e científico.

Ao Grupo de Estudos Semióticos da USP, à Paula de Souza e ao Maurício Cardoso, pelo saber compartilhado.

À minha família e aos meus amigos sempre presentes nos diálogos que fortaleceram meu interesse pela investigação.

À CAPES, pela bolsa concedida para realização desta pesquisa. 


\section{Resumo}

O presente estudo procura descrever os usos da voz nas encenações teatrais, colocando em relevo suas especificidades enquanto objeto sonoro, bem como as marcas deixadas na esfera acústica pela instância do sujeito da enunciação. Como metodologia de análise, contemplamos o arcabouço teórico da semiótica de filiação estrutural e francesa, de modo que buscamos uma primeira aproximação entre os processos de significação mobilizados pela voz do ator teatral e o modelo tensivo desenvolvido atualmente. Para chegar à parte empírica de nosso estudo, refletimos sobre as bases fundamentais da teoria, revisitando o debate sobre as definições de teatralidade contemporânea e, assim, sobre as possibilidades de análise da gestualidade vocal produzida no momento de atuação. Para a descrição de um corpus, selecionamos determinadas cenas a partir de duas elaborações cênicas diferentes, ambas concebidas por Antunes Filho, sobre uma mesma obra trágica, Medeia de Eurípides. Comparamos os usos da voz em relação às construções das personagens e aos seus posicionamentos nas situações dramáticas, observando desse modo as qualificações modais e passionais sugeridas pelas encenações.

PALAVRAS-CHAVE: semiótica, teatro, entoação, ator, encenação. 


\section{Abstract}

This study tries to describe the uses of voice in theatrical performances, emphasizing their specificities as a sound-based object, as well as the imprints left in the acoustic field because of the urgency of the subject of enunciation. As an analysis methodology, we considered the theoretical framework of structural and French-based semiotics, in order to seek a closer relationship between the processes of meaning mobilized by the theatrical actor's voice and the currently-developed tensive model. To reach the empirical part of our study, we considered the foundations of the theory, revisiting the debate on the definitions of contemporary theatricality, and therefore, on the possibilities of analysis of the vocal gestures produced at the time of the performance. For the description of a corpus, we selected certain scenes from two different scenic constructions, both devised by Antunes Filho, on the same tragic work, Medea by Euripides. We compared the uses of voice concerning the construction of the characters and their positioning in dramatic situations, thereby observing the modal and passionate qualifications suggested by the acting.

KEYWORDS: semiotics, theater, entonation, actor, staging. 


\section{Sumário}

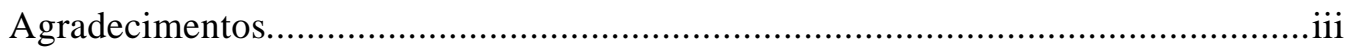

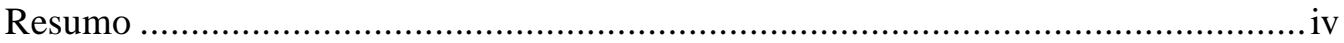

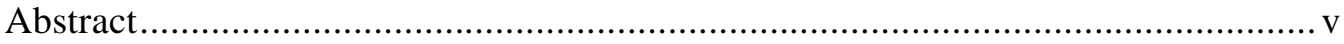

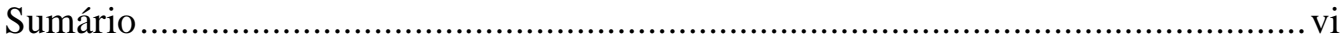

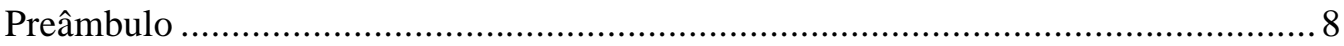

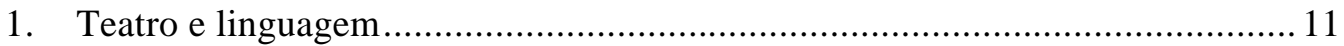

1.1 A semiótica teatral e as teorias do teatro.................................................. 14

1.2 Primeiros desdobramentos do signo e as definições de teatralidade .............. 17

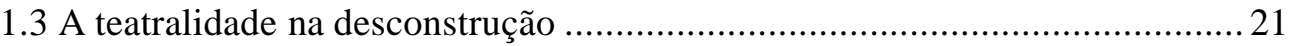

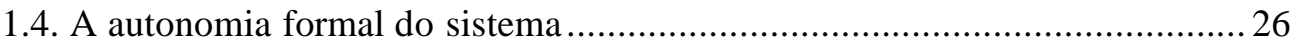

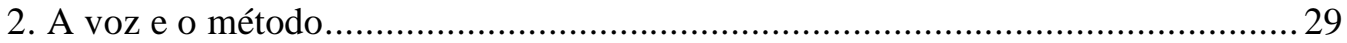

2.1 Das impressões sonoras às unidades linguísticas ......................................... 31

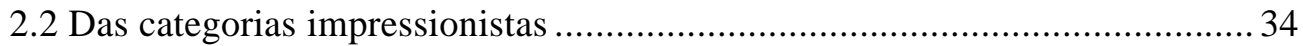

2.3 As sonoridades como um conjunto significante ......................................... 37

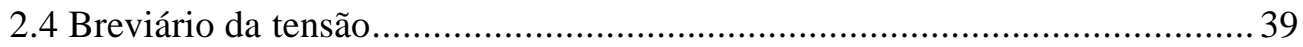

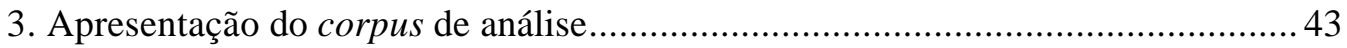

3.1 Da primeira análise (apresentação da personagem) ................................... 47

3.2 Da segunda análise (o embate com Jasão) ............................................... 48

3.3 Da terceira análise (a dissimulação).........................................................51

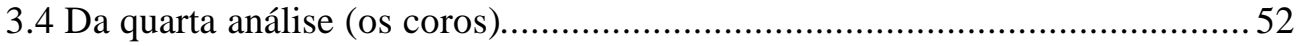

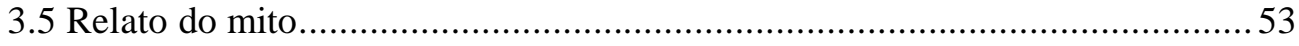

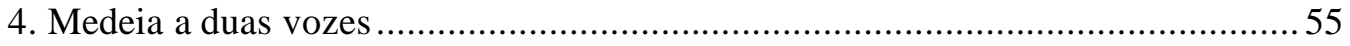

4.1 Precedentes de uma comparação ................................................................. 56 
4. 2 Medeia (M1), primeiro excerto: sobre a tensão e a dúvida...........................58

4.2.1 Segundo excerto: uma hipérbole sonora ou o exagero ambíguo................59

4.3 Medeia 2 (M2), primeiro excerto: sobre os regimes de acentuação. .............. 61

4.3.1 Do ritmo à variação implícita de seus valores .......................................... 62

4.3.2 Segundo excerto: prolepse sonora, antecipação e velocidade ..................... 64

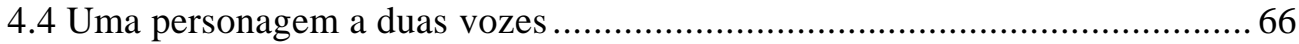

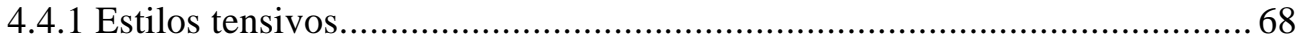

4.4.2 Gerenciamento da concomitância entre andamento e ritmo....................... 72

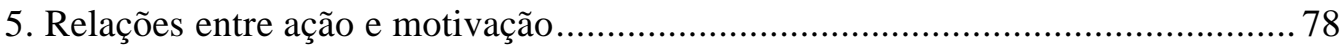

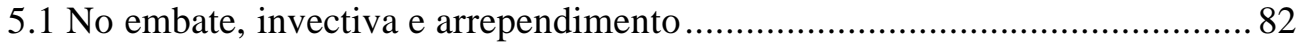

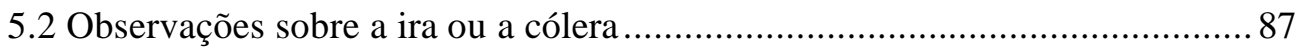

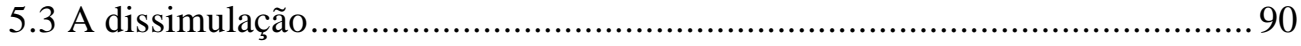

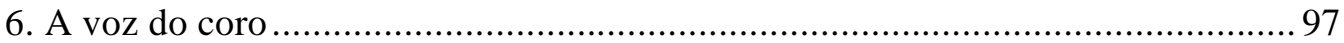

6.1 O papel do coro e o movimento catártico....................................................... 97

$6.2 \mathrm{O}$ contexto de seleção do corpus............................................................. 100

6.3 Os coros em Medeia e suas intervenções na tragédia ................................. 101

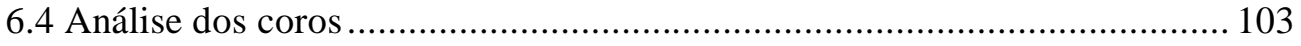

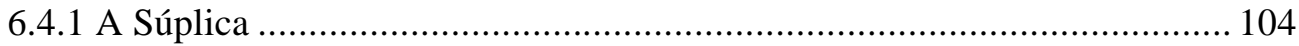

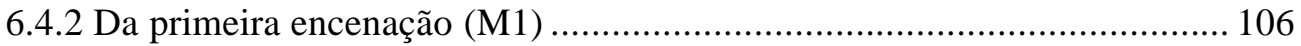

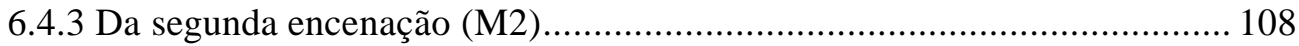

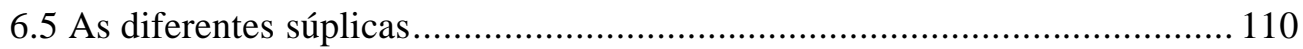

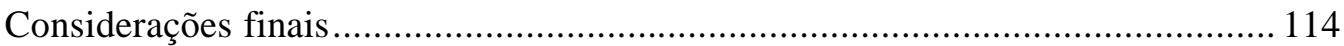

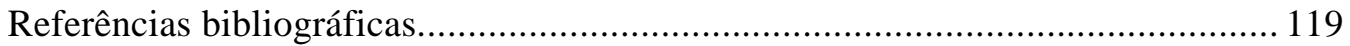




\section{Preâmbulo}

Para alcançar a descrição e a tradução dos sentidos gerados pela voz do ator nas encenações teatrais, fazemos apelo ao modelo tensivo desenvolvido na teoria semiótica atual de linha francesa.

Neste preâmbulo, traçamos os termos gerais desta dissertação, tendo em vista que o primeiro capítulo lança diretamente os questionamentos fundamentais em nosso estudo, sem introduzir de maneira canônica os procedimentos utilizados durante as análises. Assim, as definições preliminares compreendidas na apresentação do modelo aplicado seguem ao lado das reflexões teóricas e analíticas.

A pesquisa apresenta-se dividida em dois segmentos. Um deles problematiza a teoria teatral na observação dos processos de significação no teatro, enquanto o outro está ancorado nas análises das encenações propriamente ditas. $\mathrm{Na}$ parte inicial, o primeiro capítulo procura esclarecer as bases que regem nossas escolhas metodológicas, a partir do debate entre a semiótica e a teoria teatral influenciada pelos ideais da desconstrução que, por sua vez, não legitima o domínio da linguagem no que tange ao trabalho de atuação. No segundo capítulo, a metodologia é esboçada ao situar o desenvolvimento do modelo tensivo, destacando seu papel em nossa apreciação em relação a outros estudos que contemplam o sujeito falante como, por exemplo, a fonoestilística.

Nas análises propriamente ditas, os primeiros exames concentram-se nas elaborações da personagem central em duas encenações diferentes de um mesmo texto trágico, Medeia de Eurípides, dirigidas por Antunes Filho e protagonizadas por Juliana Galdino. As diversas configurações da protagonista são contempladas a partir de três cenas em cada encenação, a saber, a apresentação da personagem, o embate com Jasão e, por fim, a dissimulação de Medeia. Com isso, a estabilidade na caracterização das personagens encenadas é vislumbrada primeiramente, para depois sua mobilização na situação ser observada. Ainda nessa parte analítica, a última investigação passa à 
participação dos coros nas cenas da súplica. Os excertos analisados são encontrados nos sítios da internet (http://vimeo.com/27693293/ e http://vimeo.com/29893306), sendo acessados por intermédio de uma senha (medeiaCPT12), conforme assinalamos na apresentação de nosso corpus.

Direcionando o olhar semiótico e sua metalinguagem descritiva para os aspectos sensíveis dos procedimentos vocais utilizados no teatro, a voz vem a ser objeto de uma semiótica cujo plano da expressão é composto de sonoridades. De maneira geral, os usos da voz são avaliados a partir da percepção auditiva que, por sua vez, incide nas resultantes fonéticas e acústicas, manifestadas em nível suprassegmental. Ao perceber as unidades prosódicas como manifestações dos parâmetros acústicos (intensidade, duração e altura), surge a possibilidade de considerar uma organização dessas unidades em sequências sonoras, tornando-se necessário observar a pertinência dessas configurações e a geração de seus próprios conteúdos.

Há então dois tópicos recorrentes que acompanham as análises. O primeiro diz respeito à pertinência das segmentações para a constituição das identidades dessas manifestações textuais, pois não se trata aqui das supostas irregularidades de uma massa sonora sem forma. Pelo contrário, inúmeras formas podem ser encontradas na confluência do trabalho analítico. Cabe a nós identificar as regularidades e permanências concernentes ao discurso das personagens encenadas e conseguir representá-las na descrição. O segundo diz respeito à autonomia do objeto sonoro. Quais seriam seus conteúdos genuínos? Quais seriam os que não surgem na manifestação linguística da fala? E, por fim, como gramaticalizá-los?

Diante de cada encenação de Medeia, a descrição atenta para suas unidades constituintes e para os critérios descritivos necessários para traçar essas definiç̧ões. Os primeiros estudos das modulações vocais nas encenações de Medeia pretendem explicitar a maneira pela qual ocorre a mobilização das categorias previstas pelo modelo tensivo no exame desses textos. A partir dessa primeira aproximação, as apreciações subsequentes devem propiciar um olhar sobre a reverberação das entoações nas partes das encenações, tais como a ação e a motivação. 
Assim, os usos da voz nas construções das personagens são comentados no âmbito específico em que se dispõem, notando sua participação nos engendramentos das cenas. Considerando que a linha da entoação é apresentada por meio de sua densidade tensiva, é possível delinear as cargas patêmicas e as qualificações modais que posicionam a personagem no drama.

$\mathrm{Na}$ convergência entre duas teorias, uma sobre o gênero teatral e outra sobre os processos de significação, as possíveis equivalências no uso das terminologias foram deixadas à margem para que as análises dos discursos prosseguissem. Desse modo, as noções teatrais de personagem e de ator permanecem nesta dissertação, tendo em vista que o objeto vocal problematiza em alguma medida a relação entre essas instâncias. 


\section{Teatro e linguagem}

$\mathrm{O}$ início do século $\mathrm{XX}$ inaugura os primeiros movimentos de renovação do teatro europeu, marcados seja pelo que chamamos naturalismo de Constantin Stanislavski e Antoine Vitez, seja pelo caso polêmico de Antonin Artaud. Esse período caracteriza-se na procura por novos modos de atuação ou, até mesmo, por registros de interpretação de maneira geral. Nessa busca pela originalidade da expressão, a reflexão sobre a relação entre a escrita e a fala encenada é um dos eixos contemplados por encenadores e atores. A flexibilidade da dramaturgia escrita, suas inúmeras possibilidades de leitura e de elaboração de discursos, supre o contínuo interesse pela arte dos palcos. Tal busca permanece atual, na medida em que diversos caminhos para os usos da palavra continuam sendo explorados, particularmente no que tange à relação entre o texto e a cena.

Nosso trabalho visa pôr em relevo a palavra dramática em sua especificidade que se manifesta em formas próprias de expressão oral. Notamos que, ao se aprofundar e se radicalizar a autonomia da encenação teatral em relação à obra dramatúrgica, a noção de texto é alargada e abrem-se novas possibilidades para a análise teórica. Assumimos, portanto, que a encenação abarca, cada vez mais, uma multiplicidade de formas discursivas sobre diferentes planos de expressão. Privilegiaremos o estudo da voz e de suas textualizações, ou seja, aquilo que concerne à dimensão dramatúrgica da sua matéria sonora e, assim, da palavra posta em ação.

De maneira semelhante, no momento atual, as questões sobre os modos de atuação surgem pondo em xeque os níveis de representação e não-representação dos atores. Dentro da sala de espetáculo, é possível encontrar o ator supostamente despojado da personagem. Ranieri Gonzalez, por exemplo, comenta com o público as tatuagens que o transformam em "uma história em quadrinhos". Posiciona-se na boca

\footnotetext{
${ }^{1}$ Espetáculo Vida, da Cia Brasileira, dirigida por Márcio Abreu, estreou em 19 de março de 2010, no teatro José Maria dos Santos, Curitiba.
} 
de cena e, ao se aproximar da audiência, dá intensidade aos elementos de seu próprio cotidiano, seu corpo, sua pele e, no limite, tudo aquilo que o coloca como um sujeito específico. Quando há esse propósito de incidir sobre a personalidade do ator, a exposição no proscênio é procedimento usual. Outros mecanismos de atuação poderiam ser aventados e sua teorização sistematizaria, inevitavelmente, o que é aclamado como assistemático. De nossa parte, acreditamos que as maneiras de proceder do ator são indícios formais de uma dada construção cênica e que poderiam ser sistematizados.

Em procedimentos como esse esboçado acima, a ilusão cênica não é mais construída em segredo. Pois, com a exposição dos artifícios do meio expressivo, o espectador é convocado ao questionamento: o ator, observado na boca de cena, representa algo, ou, ao contrário, apresenta a si próprio? A tópica recorrente não pode ser mais explícita: a não separação entre a vida e a obra, qual seja, a arte do ator em representar a si mesmo ou uma personagem. Diante desse debate e do ensejo de avaliar esses papéis assumidos na atuação, procura-se compreender o teatro de "nosso próprio tempo" e, com isso, o teatro contemporâneo, apresentado durante o tempo vivido do espetáculo.

Certo viés analítico ${ }^{2}$ comenta a relação entre o artista e sua própria atuação, identificando os limites da ilusão cênica como uma misteriosa confluência de fluxos energéticos que não têm nada a dizer, sendo simplesmente não-discursivos ${ }^{3}$. Ao se apoiar na parcialidade de um teatro definido ora como representação ora como

\footnotetext{
2 "No início da década de1980, observava-se na teoria francesa uma nítida e não raro agressiva divisão entre os teóricos semióticos, que tentavam analisar os códigos teatrais e sua transmissão, e os pósestruturalistas que, como Féral, ocupavam-se dos fluxos não discursivos de energia e dos deslocamentos de libido, trabalhando nas direções sugeridas por Lyotard, Deleuze e Guatarri. (...) as abordagens divergentes dos teóricos da semiótica e da fenomenologia refletem, em larga medida, essa tensão entre teatro como comunicação e teatro como local de fluxos de energia." (CARLSON, 1997: 496)

3 "La relation de l'artiste à sa propre performance n'est plus celle de l'acteur à son rôle. Le performeur (...) Il est plutôt source de production de déplacement. Devenu le lieu de passage de flux énergétiques (gestuels, vocaux, libidinaux...). (...) Preuve encore une fois qu'une performance ne veut rien dire, qu'elle ne vise aucun sens précis et unique, mais qu'elle cherche plutôt à révéler des lieux de passage, des 'rythmes' (...)" (FÉRAL, 1985: 130-131) “A relação do artista com sua própria performance não é mais aquela do ator com seu papel. O performer (...). É fonte de produção de deslocamento. Torna-se o lugar de passagem de fluxos energéticos (gestuais, vocais, libidinais...). Prova ainda uma vez que uma performance não quer dizer nada, que ela não busca nenhum sentido preciso e único, mas que ela procura revelar lugares de passagem, ritmos (...)”(Tradução nossa).
} 
demonstração de uma dada realidade, parte das manifestações teatrais é associada à negação de sua constituição enquanto linguagem.

De fato, não é recente a discussão sobre a dualidade intrínseca à encenação. Com respeito a isso, vale lembrar d'O Paradoxo do Comediante, de Diderot. Quase um século e meio antes dos legados naturalista e realista e, com isso, da modernização da linguagem cênica, já se discutia acerca de uma teoria da sensibilidade para o ator teatral. Isto é, um ator convencia e sensibilizava a plateia, servindo-se de certa faculdade de promover entre si próprio e a personagem efeitos ora de distanciamento, ora de aproximação. Diderot compara a atuação de duas atrizes:

Mlle Clairon (...) passada a luta, depois de elevar-se uma vez à altura de seu fantasma, ela se domina, ela se repete sem emoção. (...) Com Mlle Dusmenil não acontece o mesmo que com Mlle Clairon. Ela sobe ao palco sem saber o que irá dizer; metade do tempo ela não sabe o que diz, mas chega ao momento sublime. E por que diferiria o ator do poeta, do pintor, do orador e do músico? Não é no furor do primeiro jato que os traços característicos se apresentam, é em momentos tranquilos e frios, em momentos totalmente inesperados. (DIDEROT, 1966: 168-169)

Diderot procura discutir o mito do ator possuído que realiza sobre o palco um exercício de inspiração, tomado por uma comoção incalculável, aproximando o trabalho da atuação de uma natureza essencial que não pode ser conhecida. Já em relação ao trabalho do ator glorificado por sua técnica e, afinal, por sua capacidade de cálculo, as escolhas das sonoridades vocais são ainda percebidas como um artifício sem grandes consequências para os engendramentos cênicos. A partir disso, classicamente, a voz é tomada ora como um produto das oscilações e eventualidades do ator, ora somente como um aparato técnico.

Em nenhuma dessas perspectivas torna-se possível compreender a voz como produtora de um discurso. Nossa investigação procura reverter essa impossibilidade de análise que tais perspectivas implicam. Partindo do momento da enunciação do texto, teremos como objeto semiótico os sinais de engajamento do ator nesse processo de 
significação. Isto é, a voz em si manifesta seus sentidos e colabora com as propostas estéticas das encenações.

Assim, é a partir do questionamento sobre o domínio da linguagem que voltamos às abordagens dos estudos teatrais, enfatizando o momento em si da atuação. Considerando que a expressão cênica está baseada em princípios fundamentais da linguagem, esperamos encontrar aí e em seu funcionamento espécies de dramaturgias construídas sobre as sonoridades vocais.

\subsection{A semiótica teatral e as teorias do teatro}

No intuito de fornecer as bases necessárias para a plena compreensão da parte empírica de nosso trabalho, é imprescindível esclarecer os posicionamentos teóricos diante das linguagens da encenação. Tal debate sobre as noções preliminares permite igualmente explicitar as justificativas para nossas escolhas metodológicas. Antes de expor os questionamentos que emergem a partir das análises propriamente ditas, devemos reapresentar o embate teórico esboçado nas páginas precedentes, posicionando a metodologia descritiva da qual nos valemos. Em outras palavras, as diferentes abordagens sobre o teatro constituem o pano de fundo a partir do qual se torna possível a definição de nossa própria pesquisa.

Num primeiro momento, para compreender nosso objeto, observamos a participação dos pressupostos semióticos de filiação francesa nos estudos das linguagens teatrais em relação à dramaturgia e ao espetáculo e, chegando ao momento atual, buscamos a compreensão da ausência predominante de um olhar que promova a inteligibilidade dos sistemas da encenação ${ }^{4}$.

Na polêmica em questão, outra tendência de teorização pode ser observada como mais divulgada e reconhecida. Isto é, a crítica à proposta formal e estrutural estabelece uma maneira de explicar o trabalho do ator contemporâneo ou ao "paradigma teatral

\footnotetext{
${ }^{4}$ Muitas vezes, temos de nos render à dificuldade de acessar determinadas obras e materiais que não são encontrados em nosso país como, por exemplo, as obras de Ane Goutman (Universidad Autónoma de México). Citamos de passagem A. Goutman, pois a autora parece inscrever-se na continuidade do projeto estruturalista francês voltado para a semiótica do teatro, em oposição a inúmeros outros estudos que são caracterizados pela ruptura com a episteme estrutural.
} 
da presença” (RANCIÈRE, 2009: 24). Em linhas gerais e, em especial, para os estudos estéticos, a figura de Jean-François Lyotard surge no intuito de romper com os regimes de representação e simbolização.

No ensaio apresentado na internacional de semiologia teatral, Veneza, setembro de 1972, "La dent, la paume", o filósofo formula o teatro energético derivado da polêmica artaudiana acerca da linguagem no teatro. Num primeiro momento, o autor que cunhou o termo "pós-moderno" reconhece uma estrutura no jogo teatral. Segundo Lyotard, essa estrutura é equivalente a uma organização entre duas instâncias topológicas (A e B) que se correspondem por meio de uma ordem causal entre elas. O punho cerrado é o sinal da dor, do mesmo modo que a atuação sinaliza o ator. Em seguida, nesse mesmo ensaio, é instituída uma espécie de troca de valores descodificada e não hierarquizada, o que supostamente revelaria na última instância (B) uma multiplicidade de energias que nada quer dizer (LYOTARD, 1994).

Essa tendência de reflexão sobre a cena questiona a adequação das categorias semióticas junto à constituição da atuação. Em dado momento, alguns autores, em especial aqueles identificados com o paradigma pós-moderno ${ }^{5}$, ocuparam-se da aversão ao estruturalismo e à noção de representação alegando, como contrapartida a essa dupla negativa, favorecer com isso o entendimento das manifestações teatrais contemporâneas, consideradas resistentes à tradição estrutural.

Sob essa perspectiva, o teatro é definido na oposição entre uma tradição logocêntrica e outra na qual prepondera o corpo em cena, como se esse dispensasse seus próprios sentidos. Desse modo, o espectador vai ao teatro para "ver a montagem do texto" ou para "viver uma experiência incompreensível". A partir disso, não é sem algum espanto que observamos, ainda hoje, a discussão que dispõe a linguagem teatral como tributária da literária. Está claro que essa qualidade da linguagem teatral coloca os usos da palavra realizados pelo intérprete como atrelados à reprodução de uma

\footnotetext{
${ }^{5}$ No sentido dessa ruptura, é possível ainda citar parte da obra de Jacques Derrida. Contudo, vemos que sua leitura de Ferdinand Saussure, em especial, e de seus seguidores é extremamente imprecisa. Por enquanto, deixemos essas passagens e seus pormenores, para que possamos avançar em traços gerais sobre as consequências dessas reflexões e como elas atingem os estudos teatrais.
} 
dramaturgia escrita. E, por sua vez, esse texto é tomado como uma invariável independente do corpo que lhe é dado no momento da enunciação ou da leitura.

Assim, uma visada pós-moderna domina o cenário teórico desvalorizando a análise estrutural considerada como inadequada para as novas formas de teatralização e para a compreensão do trabalho do ator. Em tal visada, encontramos a tradicional redução da linguagem teatral e de seus elementos específicos, como a participação do discurso sonoro da voz na construção dos sentidos da encenação.

Diante dessas abordagens, entendemos que a difícil objetivação da passagem da escrita para fala ou ainda do espaço da palavra na encenação permanece como um mote para inúmeras discussões teóricas e estéticas. Notamos também que, na leitura habitual feita sobre a noção de estrutura, o texto escrito parece estar sempre imanente à manifestação teatral. E, por isso, a fala no teatro é considerada somente um processo, sem que se apresente um sistema teórico adequado para descrição das escolhas feitas pelo ator.

Para chegar a essas observações, percorremos alguns argumentos desta crítica que visa abster-se do vínculo com a análise estrutural da linguagem. Explicitamos assim as demandas dessa ruptura, julgando a pertinência e a produtividade das proposições realizadas por esta crítica, tendo em vista que elas interferem imediatamente na possibilidade de compreensão da voz do ator nas encenações. Para tanto, o estatuto da noção de sistema perpassa a releitura das definições acerca da teatralidade.

Essa etapa da pesquisa torna-se necessária para o alcance da potência heurística implicada na análise semiótica, na exposição de uma questão primordial: a explicitação dos princípios regentes na definição dos objetos teóricos ou as bases que fundamentam os estudos das linguagens estéticas e, mais especificamente, daquelas que o teatro abarca e sintetiza. Procuramos, portanto, contemplar as reflexões teóricas gerais configuradas a partir do questionamento sobre o papel discursivo da voz no teatro. Isto é, quando as teorias ocupam-se das definições do espetáculo, elas assumem ou não a dimensão discursiva da voz do ator? 


\subsection{Primeiros desdobramentos do signo e as definições de teatralidade}

$\mathrm{Na}$ antologia organizada por Jacó Guinsburg, Teixeira Coelho Neto e Reni Chaves Coelho, intitulada Semiologia do Teatro, é possível encontrar alguns textos das "fontes batismais" desse campo de investigação. Esses estudos datam a partir de 1937 e são elaborados por autores como Jindrich Honzl, Jan Mukarovsky, Petr Bogatyrev e Roman Ingarden. Com eles, surgem as primeiras possibilidades de uma metodologia para análise dos espetáculos. Nesse sentido, a noção de sistema colabora como um pressuposto para a apreensão da multiplicidade expressiva que caracteriza essa manifestação (HELBO, 1983: 18).

Nos postulados estruturais que encontramos nesses textos, o questionamento sobre "a natureza do signo teatral" pode ser reconhecido na origem de outro termo caro aos estudos teatrais da atualidade: a teatralidade. Obviamente, essa última noção não é empregada de maneira uniforme, não apresentando um consenso nas menções dos diferentes autores (PAVIS, 2000; FÉRAL, 1988). Sendo assim, convém ressaltar certos aspectos na "invenção" desse conceito (SARRAZAC, 2000).

Essa noção é inserida na crítica teatral num momento em que a semiótica ou, nesse caso, a semiologia, considerando como Roland Barthes evocava o projeto saussuriano, ocupava um espaço de grande prestígio entre os pensadores da área. Assim, notamos que o tema da teatralidade aparece na influência exercida pelos estudos dos signos, no momento em que o estruturalismo era observado como um método voltado para as humanidades.

Além disso, a teatralidade destaca a possibilidade da autonomia de formas próprias das expressões no espaço cênico, já que ela significava a "emancipação" da encenação em relação às obras literárias. Tendo em vista esse último aspecto que a define, a obra de Bernard Dort exemplifica a necessidade de reflexão acerca das propriedades dessa manifestação.

L'avènement $\mathrm{du}$ metteur en scène et la prise en compte de la représentation comme lieu même de la signification (nom comme traduction ou décoration d'un texte) n'en ont, sans doute, constitué 
qu'une première phase. Constatons aujourd'hui une émancipation progressive des éléments de la représentation et voyons-y un changement de structure de celle-ci: le renoncement à une unité organique prescrite $a$ priori et la reconnaissance du fait théâtral en tant que polyphonie signifiante, ouverte sur le spectateur. (DORT, 1988: $178)^{6}$

Na edição da revista Théâtre Populaire (1953 - 1964), Dort era companheiro de Barthes. E, na verdade, a inserção do termo na crítica do teatro francesa é atribuída a Barthes, com a publicação do texto Le Théâtre de Baudelaire, em 1954, e depois retomado nos Essais Critiques, de 1964:

Une notion est nécessaire à l'intelligence du théâtre baudelairien, c'est celle de théâtralité. Qu'est-ce que la théâtralité? C'est le théâtre moins le texte, c'est une épaisseur de signes et de sensations qui s'édifie sur la scène à partir de l'argument écrite, c'est cette sorte de perception ecuménique des artifices sensuels, geste, tons, distances, substances, lumière, qui submerge le texte sous la plénitude de son langage extérieur. Naturellement, la théâtralité doit être présente dès le premier germe écrit d'une oeuvre, elle est une donnée de création, non de réalisation. (BARTHES, 1993: $1194-1195)^{7}$

Na nota introdutória dos Essais, de 1971, Barthes posiciona esses ensaios em relação ao seu percurso intelectual e às ideias europeias e, em especial, às parisienses. Ele aponta o ensejo dessa reflexão como resultante das primeiras consequências do projeto semiológico saussuriano e dos debates sobre sua junção com o marxismo e com a psicanálise nas teorias althusseriana e lacaniana. Entre 1966 e 1967, as

\footnotetext{
6 "O advento do encenador teatral e a tomada de consciência da representação como o lugar próprio da significação (não como tradução ou decoração de um texto) constituíram somente uma primeira fase. Constatamos hoje uma emancipação progressiva dos elementos da representação e vemos aí uma mudança na estrutura: a renúncia de uma unidade orgânica prescrita a priori e o reconhecimento do fato teatral enquanto polifonia significante, aberta sobre o espectador." (Tradução nossa).

7 "Uma noção é necessária à inteligência do teatro de Baudelaire, é aquela de teatralidade. O que é a teatralidade? É o teatro menos o texto, é uma densidade de signos e de sensações que se constrói sobre a cena a partir de um argumento escrito, é essa sorte de percepção ecumênica dos artifícios sensoriais, gesto, tons, distâncias, substâncias, luz, que submerge o texto sob a plenitude de sua linguagem exterior. Naturalmente, a teatralidade deve estar presente desde o primeiro germe escrito de uma obra, ela é um dado de criação, não de realização.” (Tradução nossa).
} 
primeiras interlocuções entre estas teorias são reapresentadas pelas leituras de Jacques Derrida e Julia Kristeva. (BARTHES, 1993: 1167)

Com isso, observamos tanto a transformação dos termos "teatralidade" e "estrutura" ou "sistema", quanto suas imbricações recíprocas no seio dos estudos teatrais. No princípio dessas reflexões teóricas, há uma preocupação em estabelecer uma hierarquia no interior dos espetáculos entre as modalidades da linguagem verbal, a escrita e a fala. Nesta partição vemos que a dicotomia (língua/fala ou sistema/processo) transportou-se para o âmbito teatral. Dispomos, de um lado, um suposto conjunto de enunciados estáveis escritos que configurariam o sistema e, de outro, as oscilações do processo da fala em cada enunciação ou representação.

Dessa maneira, a figura do escritor dramático passa a encarnar uma estrutura materialmente definida ou, até mesmo, um sistema ditador de regras. Em relação a essa determinação, ou o ator a subverte ou lhe é fiel, neste último caso investigando as "reais" intenções do autor. Diante disso, contemplamos dois problemas no aproveitamento do sistema para a teatralidade. Na maioria das vezes, tal sistema acarreta uma hierarquia entre a letra e a voz, o que posiciona a escrita como uma determinante central da teatralidade, impondo sua primazia sobre a encenação. Em meio a isso, surge o problema da doação do ator, que não se configura como uma escolha em relação aos projetos estéticos, mas sim como condicionamento obrigatório de seu trabalho. Assim, a noção de sistema perde sua potência heurística, visto que ela colabora pouco para dar relevo à entidade espetacular da atuação que, por sua vez, permanece à margem da possibilidade de formalização ou de sistematização. ${ }^{8}$

Ainda como uma consequência desse pensamento, o ator é destinatário de uma manipulação que, modalizando essa posição, aceita ou não ser um simples porta-voz de algo que lhe é, por vezes, completamente alheio. E, em relação às suas próprias

\footnotetext{
${ }^{8}$ Diante desse tema que coloca em relação o sujeito e o significante, convém lembrar o ensaio "Palavra Soprada”, publicado na A Escritura e a Diferença (1967), próximo ao ano em que Barthes localiza os primeiros desdobramentos da noção de signo: "A palavra proferida ou inscrita, a letra, é sempre roubada. Sempre roubada. Sempre roubada porque sempre aberta. Nunca é própria do seu autor ou do seu destinatário e faz parte da sua natureza jamais seguir o trajeto de um sujeito próprio a um sujeito próprio. O que significa reconhecer como sua historicidade a autonomia do significante que antes de mim diz sozinho mais do que eu julgo querer dizer e em relação ao qual o meu querer dizer, sofrendo em vez de agir, se acha em carência, se inscreve, diríamos nós, como passivo." (DERRIDA, 2002: 121)
} 
falas, ele acaba por simbolizar ou o sujeito enunciativo que possui uma voz ativa e performativa ou, ao contrário, uma voz passiva e manipulada por uma instância superior, o autor dramático.

De qualquer maneira, assumindo ou não a anterioridade da literatura, a reflexão acerca da teatralidade tem procurado a todo custo legitimar as dimensões da linguagem do palco. Vemos com isso a existência de um consenso implícito segundo o qual atores e encenadores não seriam meros executantes. Para apreender os discursos da atuação e de sua dimensão criativa, a noção de uma estrutura da teatralidade deve necessariamente ser revisitada. Na medida em que toda posição tomada acerca do sentido na teatralidade reflete sobre escolhas estéticas e determinados processos de significação, o texto escrito não pode de maneira alguma ocupar de antemão o espaço de um "sistema orgânico" e integral, em relação ao qual o palco seria somente um aparato decorativo (DORT, 1988: 178).

Desse modo, faz-se mister compreender melhor a influência da semiótica seja no sentido de sua vertente barthesiana, seja no interior do conceito de teatralidade segundo os diferentes autores. Convém, portanto, enfatizar que as elaborações teóricas acerca da teatralidade podem também ser apreciadas como uma resultante daquilo que o método estrutural promove. Contudo, essa questão teórica é negligenciada no que tange à encenação quando a estrutura repousa sobre a palavra escrita, enquanto a falada se perde.

$\mathrm{Na}$ falta de clareza sobre os sistemas da encenação e, por consequência direta, do teatro vivido e tomado como uma experiência, as reflexões sobre a teatralidade postulam uma instância anterior, além ou aquém da linguagem e de seu princípio de sistematização. Neste caso, a voz do ator permanece um território desconhecido que convoca os recursos de compreensão do método semiótico.

Diante disso, é interessante localizar o pensamento da franco-canadense Josette Féral, importante autora na medida em que reflete uma transformação nos estudos teatrais. Ela obtém seu doutoramento em 1978, sob a orientação de J. Kristeva. Num primeiro momento, a influência dos estudos do signo é declarada. Num outro, ela é rechaçada. Na medida em que se estabelece essa ruptura ao lado de diferentes 
formulações sobre a encenação, a teatralidade é redefinida. Com isso, devemos localizar o que é tomado como justificativa desse rompimento.

\subsection{A teatralidade na desconstrução}

De maneira geral, no âmbito dos estudos teatrais, a crítica ao estruturalismo é perpassada pelo problema no estabelecimento de um sistema a priori. Tal crítica argumenta que a natureza efêmera da teatralidade não pode ser prevista inteiramente pela estrutura. Um dos desdobramentos desse entendimento considera que as categorias convocadas pela materialidade da encenação acabam por não pertencer à ordem da linguagem seja ela compreendida como sistema de signos, seja como representação simbólica. O fundamento desse argumento é a crença de que no seio da teatralidade encontraríamos uma espécie de realidade independente da linguagem.

Diante das várias referências que convergem em uma teoria teatral, Féral (2000) assume a teoria enquanto tradução e descarta rapidamente os postulados estruturais. A partir disso, sentimos a obrigação de refletir sobre as diferentes propostas teóricas e metodológicas e, mais precisamente, sobre as prerrogativas e os alcances da teoria ao posicionar seus objetos de estudo.

Pensemos no estruturalismo, em particular na semiologia. Os investigadores abandonam essa vontade cientificista que marcou a época estruturalista e a que seguiu a época em que a semiologia conquistadora marcou a declinação ao revelar a sua impotência para compreender e penetrar os sistemas (FÉRAL, 2000: 11. Tradução nossa.)

Nessa passagem, vemos que o termo sistema que, aqui, ainda não foi abandonado, designando o objeto de estudo de sua proposta teórica. Todavia, ainda segundo essa autora, uma investigação pode ocorrer fora do sistema e na oposição ao estruturalismo. Em outro trecho, o mesmo termo parece configurar trajetórias de análise opostas: "o investigador não está mais a procura de modelos para aplicar, de 
tabelas de análises que permitam decodificar sistemas diferentes. Não busca mais estruturas fundamentais: desconstrói a obra.” (FÉRAL, 2000: 11. Tradução nossa.)

É nítido o apelo a uma teoria da desconstrução oposta a uma da construção, esta identificada aos modelos estruturalistas. Com isso, também é possível notar que a noção de sistema solicita uma consideração sobre os procedimentos necessários que delineiam o trabalho investigativo. Assim, na medida em que a autora estabelece o confronto entre duas vias heurísticas distintas, é necessário compreender a diferença entre os sentidos da noção de sistema evocado por Féral.

Nesse artigo, “Que peut (ou veut) la théorie du théâtre?”, a atividade científica da semiologia é colocada como uma simples produção de modelos, ou seja, um exercício de criação de ferramentas interpretativas. Esses modelos são entendidos como baseados em uma estrutura que definiria completamente os processos de significação. Esta abordagem critica um analista que constrói artificialmente um sistema a priori. Depois, ele pode sair pelo mundo, instaurando seus postulados ou procurando alguma prova ou evidência, para afirmar que essas ou aquelas categorias são boas ou, ao invés disso, são falsas. Assim, não é necessário nem mesmo compreender as manifestações ou os textos, visto que anteriormente a estrutura os define completamente.

Munidos desse estereótipo, como verificar o corolário da dupla enunciação elaborado por Anne Ubersfeld ${ }^{9}$ ? Certamente, quando nos deparamos com uma ampla formação de conceitos, nos perguntaremos qual é a relação entre a teoria e a prática? Pois, efetivamente, com a exclusividade em um dos elementos dessa oposição, a teoria é posicionada como um conjunto de ideias muito distante da prática.

Em contraposição a esses exemplos, temos de ressaltar que a proposta estruturalista não é exatamente equivalente ao que se diz sobre formalismo. Mesmo

\footnotetext{
${ }^{9}$ Para A. Ubersfeld, autora que explora a semiótica do teatro, uma das condições do discurso teatral é contemplada na passagem do texto à cena e no desdobramento do sujeito enunciativo. Um é imediato, o autor que compreende a totalidade das didascálias; outro é mediato da enunciação, uma personagem. As didascálias são observadas como elementos "concretos", que "comandam" a representação abstrata e imaginária das personagens (UBERSFELD, 2005: 159-161). Com isso, os problemas da autoria e da intencionalidade permanecem diante de tal concepção de discurso teatral.
} 
sem esmiuçar a complexidade desse termo, assinalamos que, por vezes, o chamado formalismo:

(...) torna-se francamente pejorativo quando qualifica as pesquisas realizadas nas ciências humanas que utilizam, no seu instrumental metodológico, procedimentos formais. Assim, a semiótica é acusada frequentemente de ser formalista e de "desumanizar" o objeto de suas pesquisas (...) (GREIMAS e COURTÉS, 2008: 220)

Pensamos que, dependendo da maneira como se compreende essas noções, o sistema não constitui simplesmente um esquematismo abstrato transcendente à matéria. Ele não é meramente uma adaptação reducionista que perpassa da representação abstrata à realidade concreta, ou seja, as categorias semióticas não impõem a contragosto suas definições gerais às manifestações particulares. Pois, quando afirmamos que as estruturas são imanentes, queremos dizer que elas são condicionamentos necessários ao entendimento e à conformação de um saber diante de uma obra e de um evento artístico que convocam, ao seu tempo, as próprias categorias que os definem e que lhes são conformes. Mais ainda, a estrutura exerce uma função constitutiva na matéria que elas informam (no sentido, de dar forma). Neste sentido, essas formas possuem uma função eminentemente produtiva.

Féral (2000), desconsiderando as premissas racionalistas da semiologia, propõe então uma maior proximidade entre o investigador e o investigado. $\mathrm{O}$ sistema fruto da desconstrução sofre com o que condiciona um julgamento: ele somente pode ser considerado a posteriori, pois ele é gerado na sanção da performance e a partir da experiência sensível do observador. Desse modo, a noção da teatralidade é redefinida ao perpassar o jogo perceptivo entre o observador e o ator.

Porém, antes de tratarmos da redefinição da teatralidade contemplada na teoria da desconstrução, é necessário dar atenção a essa espécie de desconstrução que evoca certo saber empírico. De maneira habitual, o empirista vê a si mesmo como um observador mais ou menos neutro que sai pelo mundo coletando dados, supostamente, naturais. Em seguida, ele classifica as singularidades para finalmente chegar às generalidades abstratas. Sendo assim, o "sistema" resultante da atividade de 
desconstrução é o resultado de um procedimento de indução, como classicamente se entende a atividade de exploração empírica.

De fato, radicalização dessa abordagem não suporta a sistematização, visto que somente se pode dispor de um olhar na singularidade de cada ato. É isso justamente o que podemos encontrar em outro ensaio de Féral (1985), "Performance et théâtralité: le sujet démystifié”. Neste texto, a ascensão da experiência sensível torna-se a recusa da estrutura e possui como uma resultante direta a impossibilidade da análise. Mediante as coerções da encenação, esse discurso teórico deve se contentar em traduzir o vivido, sempre a posteriori e de modo parcial.

Uma reflexão crítica sobre os pressupostos e os limites do empirismo é de extrema importância para a defesa da importância das análises estruturais. Na medida em que a noção de sistema não pode ser confundida com o correlato abstrato do realismo do dado, consideramos que os sistemas constituem as formas definíveis no interior da investigação dos acontecimentos desenrolados na expressão cênica.

Como já dissemos, em um primeiro momento, a noção de teatralidade instaura como seu objeto de investigação os processos de significação atinentes às expressões cênicas. Com isso, a procura do método é fortemente marcada pelas coerções das materialidades expressivas entendidas como ocorrências ou oscilações na temporalidade vivida. Mas, voltando-se para esses artefatos, a teoria influenciada pela desconstrução demarca a teatralidade não mais como representação, mas, sim, como a apresentação do real.

Essa intrusão da realidade, assumida pelo sujeito em cena, enuncia alguns atributos paradoxais: ela nada quer dizer, mas ela é traduzível pela metalinguagem da qual a teoria inevitavelmente lança mão; ela não é narrativa, embora esteja em conjunção com algo pessoal e biográfico; ela é o presente contínuo, conquanto revele um passado primordial.

La performance apparaît ainsi comme une forme d'art dont l'objectif premier est de défaire les «compétences" (théâtrales essentiellement). Ces compétences, elle les réajuste, les redispose dans un déploiement désystématisé. On ne peut éviter de parler ici de 
« déconstruction » mais au lieu qu'il s'agisse d'un geste « linguisticothéorique », il s'agit là d'un vrai geste, une gestualité déterritorialisée. (FÉRAL, 1985: 138) ${ }^{10}$

Nesse excerto, o sistema reaparece com o mesmo prefixo da desconstrução. Com isso, duas questões estão implicadas. De um lado, a dessistematização delimita a performance tanto como um gênero específico quanto como uma tendência do teatro atual. De outro, essa definição caracteriza a performance como algo da ordem do dado natural "desterritorializado", situando-a fora da cultura.

Segundo este modelo desconstrucionista, o corpo e sua voz em cena encerram o sujeito enunciativo em si mesmo como uma unidade permanente e verdadeira. E, desse modo, a materialidade de sua expressão torna-se um suporte para atribuição de predicados que condicionam instância enunciativa à imobilidade. Diante disso, as possibilidades de investigação sobre a expressão dessa instância dificultadas, na medida em que os dispositivos dessas linguagens não são considerados nem mesmo como evidências.

Desse modo, por oposição à teatralidade tradicional, a performance ou a happening art tem delineada suas propriedades. Há no teatro de seu próprio tempo um sujeito do desejo, o artista em si. $\mathrm{Na}$ negação das competências teatrais, as personagens não são mais capazes nem de narrar nem de demonstrar determinados fatos. Elas nem mesmo podem ser chamadas de personagens, pois sem essas competências significantes e que indicam um querer dizer, essa forma de atuação é o próprio silêncio e o vazio.

Com essa classificação estabelecida para o entendimento da manifestação contemporânea, a discussão sobre o papel da teoria é transfigurada. Seu papel não é mais compreender o conjunto de procedimentos necessários para apreender as encenações. Pois a teatralidade na desconstrução reflete a recusa tanto da teatralidade

\footnotetext{
10 “A performance surge como uma forma de arte onde o primeiro objetivo é desfazer as competências (essencialmente teatrais). Essas competências, ela as reajusta, as redispõe em um deslocamento desistematizado. Não se pode evitar de falar aqui de desconstrução, mas no lugar do que se tratava um gesto "linguistico-teórico", trata-se de um verdadeiro gesto, uma gestualidade desterritorializada." (Tradução nossa).
} 
quanto do método. O antiteatro está voltado a partir de sua definição para a apreensão daquilo que é dito como inapreensível.

Há ainda uma contradição fundamental que se deixa ver na profusão dos oxímoros que permeiam esse discurso teórico. Pois, primeiramente, para alcançar o indizível, as proposições relatam a anterioridade de uma instância que despreza a linguagem e sua articulação. Nesse mesmo instante, pela via de formalização que a linguagem proporciona, ela pode ser reconhecida. Por fim, a linguagem é ostentada na organização promovida por essa "tradução" do não verbal para o verbal.

Diante dessa prerrogativa de teorização da teatralidade contemporânea, temos de revogar a anterioridade da linguagem e de seu sistema. Afinal, se a teoria é engendrada por meio de uma metalinguagem descritiva, ela não prescinde da linguagem e, em última análise, não despreza nem mesmo a elaboração estética e discursiva dessas instâncias enunciativas (a voz e o corpo do ator). Isto é, consideramos que o sistema e sua autonomia formal promovem uma hipótese de leitura dos espetáculos. Quer dizer, a estrutura deve ser tomada, sobretudo, como um princípio operacional, gerando a seleção ou a abstração dos sentidos potenciais das manifestações e o reconhecimento de suas formas.

\subsection{A autonomia formal do sistema}

Procuramos definir a teatralidade e a especificidade da linguagem teatral através do trabalho dos intérpretes que, com seu corpo e sua voz, produzem seus discursos e colaboram para os sentidos promovidos na encenação. Nesse sentido, um estudo semiótico do uso da voz na prática teatral está atrelado imediatamente com a questão da atuação e, desse modo, com o "adensamento de signos e de sensações" que lhe é característico (BARTHES, 1993: 1194 - 1195). Assim, resgatamos a possibilidade de observar a inteligibilidade desses sistemas, tradicionalmente, compreendidos como sensíveis e, por isso, inacessíveis ao entendimento.

Por essa via, visamos suspender o embaraço que surge necessariamente de uma oposição entre o continuum sensível e o conhecimento que se debruça sobre suas 
potencialidades de sentido. Em outras palavras, nos posicionamos de maneira contrária à parte do debate que defenda uma oposição radical entre um suposto formalismo do método estrutural e uma realidade subsistente de maneira externa à linguagem. Sublinhamos isso na medida em que, de fato, uma parcela considerável das discussões estéticas defende um posicionamento deste tipo, considerando a estesia como um estado anterior e exterior à linguagem, ou seja, externo ao seu simbolismo, fundamentalmente não articulado e sem forma.

Por ora, nos atemos ao ponto de partida metodológico, segundo o qual as categorias semióticas configuram a via régia de acesso tanto às substâncias manifestadas, quanto às suas qualidades sensíveis. Sendo assim, a concepção da linguagem como estrutura destaca seu papel não somente na geração do sentido propriamente dito, mas igualmente do próprio método de análise e das categorias articuladas por ele. Com isso, não é possível prescindir da noção de estrutura porque ela funciona ao mesmo tempo como um princípio classificatório, do ponto de vista tipológico, e como um princípio heurístico de investigação, do ponto de vista epistemológico.

Além de destacar a estrutura da linguagem na sua descontinuidade, como uma ferramenta da razão colocada entre o observador e o objeto, ela surge também na qualidade do contínuo, sendo ela mesma integrante e constituinte de seu próprio objeto. Ou melhor, na compreensão da voz em relação aos recortes da análise inerentes às espécies de apreciação, devemos também considerar que a estrutura destaca, em diferentes instâncias desta mesma análise, o lugar do método e do objeto.

Assim, mesmo num teatro chamado de não-representação, diferenciado da reprodução fiel do texto escrito, subsiste um teatro de matérias e formas e o ator não deixa de ser ator. E, então, como num jogo de posições assumido entre o ator e o observador, vemos que ambos experimentam da ilusão declaradamente construída e daquela outra, que se esconde. A voz é projetada entre essas posições iniciais tomadas como possibilidade de sistema e processo de significação. No vaivém, os papéis da relação são ambivalentes em uma espécie de dubiedade intrínseca, e sofrem reversibilidade entre suas posições. 
Desse modo, o objeto vocálico percorre o interior da linguagem, o que transforma seu sistema formal na própria continuidade desse jogo. Consideramos que a semiótica oferece uma via realmente fecunda para a análise dos processos de significação nas encenações teatrais, pois, no limite de sua especificidade, a dimensão vocal constitui-se como um fato de análise. 


\section{A voz e o método}

Para compreender a geração de sentidos no interior dos discursos proferidos, grande parte do trabalho do analista consiste na procura dos procedimentos de análise e, em nosso caso, na composição dos critérios pertinentes para abarcar a multiplicidade intrínseca ao objeto vocal. Logo de início, é necessário notar que as apreensões possíveis mostram como a metodologia transfiguraria seu objeto ao posicioná-lo formalmente.

Diferentes modos de abordar a voz são encontrados em La Voix et Son Temps, de Herman Parret (2002). Diante da diversidade dos modelos teóricos que procuram defini-la ou, de outro modo, das técnicas que querem educá-la, a voz é tomada como um objeto complexo, ou seja, como um termo que pode ser decomposto em outros termos. Na esteira de H. Parret, aceitamos a possibilidade de investigação pluridisciplinar da voz e, para tanto, as maneiras de apreender com as quais tal investigador é identificado. Desse modo, as sonoridades vocais são contempladas na plasticidade e na potencialidade de seus conteúdos afetivos seja pela fonoestilística, que tem como principal predecessor a figura de Nicolas Troubetzkoy, seja pela inclusão da afetividade na retórica e ainda, melhor dizendo, pela especulação de uma retórica musical.

Contudo, gostaríamos de destacar a especial relevância das categorias tensivas na procura da inteligibilidade dos textos construídos pela voz, visto que a própria descrição do corpus de análise aponta para o encontro dessas categorias. Assim, do ponto de vista metodológico, a descrição sugere o avizinhamento entre duas metalinguagens distintas, sendo uma voltada para as categorias geradas pelas impressões acústicas e outra relativa aos conceitos que constituem o espaço tensivo da significação. Visamos esclarecer essa aproximação, ao acreditar que as sonoridades já apresentam indícios da dimensão tensiva do sentido. Para tanto, procuraremos 
diferenciar a visada tensiva de outra em que as unidades pertinentes ainda são configuradas a partir do fonema.

Tendo o modelo tensivo revelado uma metodologia produtiva a partir da dedução da base temporal e, por assim dizer, rítmica, o temário (corpo, voz e tempo) pode ser acomodado dentro de uma teoria geral da linguagem, em conformidade com a semiótica francesa atual, mesmo que sob a égide de contínuos debates. Tomada ora como um alargamento de suas bases teóricas, ora como uma abertura de seu campo analítico, a presença desses temas subjacentes aos estudos da significação é referida à obra saussuriana e, portanto, aos próprios fundamentos da reflexão semiótica. H. Parret (2002) sublinha as menções à criação de uma disciplina "fonética semiológica" nos manuscritos que Saussure nunca publicou.

Il s'agit de constituer une "phonétique sémiologique». Ce qui intéressera le "phonéticien sémiologique» est l'équivalence sémiologique. Cette phonétique ne peut se faire qu'en se libérant d'une certaine attitude "naturelle», d'une certaine façon de parler "moulée sur cette supposition involontaire d'une substance». C'est pourquoi le théoricien se laissera constamment interroger par la question: Qu'est ce qui est définissable? Le progrès dans la délimitation méthodique de son objet exige que l'on mette entre parenthèses (...) toutes les qualifications que l'attitute naturelle nous a imposées. D'abord, il faut éliminer de la phonétique sémiologique les qualifications mécanique, physiologique, articulatoire. (PARRET, 2002: 56$)^{11}$

Assim, a exigência de definição do objeto vocal dispensa uma "atitude natural", em que a voz é apreendida tal qual uma identidade definível por si mesma. A partir disso, seus componentes físicos são segmentados e, em seguida, recebem diferentes

\footnotetext{
11 "Trata-se de constituir uma "fonética semiológica". O que interessará ao "foneticista semiologista" é a equivalência semiológica. Esta fonética somente pode se constituir ao se liberar de certa atitude "natural", de certa maneira de dizer "moldada sobre esta suposição involuntária de uma substância". Isto porque o teórico se deixará constantemente interrogar pela questão: o que é definível? O progresso na delimitação metódica de seu objeto exige que se coloque entre parênteses todas as qualificações que a atitude natural nos impôs. De início, é necessário eliminar da fonética semiológica as qualificações mecânica, fisiológicas, articulatórias." (Tradução nossa)
} 
atributos (QUÉRÉ, 2001: 13). Em outra atitude, com a qual nos afinamos, a segmentação dos componentes apresenta-se por meio de uma sintaxe implícita. Desse modo, as sonoridades são representantes das tomadas de posições sintáxicas e, antes disso, dos procedimentos de análise.

Dito isso, percorremos um breve trajeto sobre as diferentes abordagens das sonoridades vocais. Tratamos da fonoestílistica e, na sua sequência, das categorias impressionistas ou, em termos parretianos, fenomenológicas, que qualificam os aparecimentos vocálicos, trazendo elementos para atividade descritiva e, por consequência, predicativa do analista. Por fim, procuramos diferenciar essa atividade da semiótica tensiva, levando em consideração as linhas da entoação no que tange à prática teatral.

\subsection{Das impressões sonoras às unidades linguísticas}

Como uma disciplina auxiliar da linguística geral, o estudo da oralidade ancorado no plano de expressão vocal traça sua trajetória de investigação passando da acústica aos conteúdos indexados ao signo linguístico. Sendo assim, julgamos lícito observar essa vertente de estudos da fonação, considerando que a voz humana, como produção do falante, integra os merismas substanciais da segmentação linguística e é também objeto abstrato do tratamento formal. Há, com isso, um vínculo estreito entre a fonoestilística e a unidade linguística, de maneira que essa última é compreendida, por vezes, na sua modalidade positiva pelas reduções empíricas.

De início, tendo contemplado a fonologia estrutural tradicional, Parret destaca que, em decorrência da preocupação com as primeiras unidades da língua, a voz, o corpo, e o tempo são fundamentalmente contingenciais ou, nos termos de Parret, constituem os materiais do "rechaço" da axiomática saussuriana (PARRET, 2002: 53).

La voix, en linguistique structurale, n'est ni plus ni moins qu'un indéfinissable, et la sonorité spécifique des voix y est considérée comme une «matière" sans structure puisqu'on est dans la pure variabilité. (...) La voix n'est en fait, pour le phonologue, qu'un ensemble flou, une silhouette informe, de particularités acoustico- 
articulatoires que, tout comme le «corps des mots », ne peut même pas être considérée comme le résidu de la forme phonématique. (PARRET, 2002: 51) ${ }^{12}$

Esse ponto de vista assinalado por Parret (2002) expõe a definição do objeto linguístico em relação ao qual a voz pode ser considerada uma coextensão meramente acidental. Entretanto, determinando os limites das unidades linguísticas, são aventados os princípios da hipótese estrutural para o conhecimento dos processos de significação. Pois, tendo em vista a autonomia do sistema linguístico, é necessária a exclusão das irregularidades presentes no concurso das circunstâncias para o reconhecimento das constâncias constituintes desse objeto.

Com a esquematização de operadores abstratos, a forma fonemática surge como uma contraproposta hjelmsleviana ao empirismo liderado pela escola de Praga. Diante das aporias entre as escolas estruturalistas, convém ressaltar brevemente que Louis Hjelmslev alerta os linguistas para a hipóstase da forma e da substância, ou seja, para que esses estratos da expressão linguística fossem então configurados como conceitos operacionais, funcionais, o que finalmente elimina um ipsum factum na determinação da teoria geral.

On reprenait à son compte l'antique hypostase de la forme et de la substance, et l'on n'eut pas le temps de détache également ce nouveau terme de la substance, d'autant que le positivisme de l'époque fasait de la matière la seule réalité, et considérait la forme comme une abstration arbitraire. Il est pourtant intérressant d'observer que cette hypostase de la forme e de la substance, l'indentification d'élément de l'expression et du son linguistique, ne fut introduite consciemment dans le système qu'assez tard. (HJELMSLEV, 1985: 155) ${ }^{13}$

\footnotetext{
12 “A voz, em linguística estrutural, não é nem mais nem menos que um indefinível, e a sonoridade específica das vozes é então considerada como uma "matéria" sem estrutura, pois que está na pura variabilidade. A voz é de fato, para o fonólogo, somente um conjunto vago, uma silhueta informe, de particularidades acústico-articulatórias que, como todo o "corpo da palavra", não pode nem mesmo ser considerado como resíduo da forma fonemática." (Tradução nossa)

13 "Retomávamos a antiga hipóstase da forma e da substância e não tivemos tempo de extrair regularmente esse novo termo da substância, enquanto o positivismo da época fazia da matéria a única realidade, e considerava a forma uma abstração arbitrária. Entretanto, é interessante observar que esta hipóstase da forma e da substância, a identificação do elemento da expressão e do som linguístico, foi introduzida conscientemente no sistema tardiamente." (Tradução nossa)
} 
Com isso, tendo se tornado uma ciência da linguagem em geral, a semiótica passa a abarcar os discursos verbais e não verbais, respeitando a hipótese estrutural para a compreensão das línguas. Propõe, assim, que seu objeto de saber não é definível em si mesmo, mas somente pelos procedimentos que viabilizam sua análise e, enfim, explicitam seus mecanismos de construção.

Diante disso, os estudos fonoestilísticos são considerados uma disciplina acessória da linguística, observando a substância residual da fonologia articulatória que, por sua vez, transforma-se em outro contínuo passível de descrição por outras formas, nesse caso, reduzidas das flutuações suprassegmentais. Seja como uma matéria disforme decorrente da experiência linguística, seja como uma substância residual que caracteriza o sujeito falante, essa abordagem é incorporada à transmissão do código verbal.

Tomando o conjunto significante das sonoridades em relação ao objeto linguístico, a manifestação sonora da fala recebe diferentes tratamentos formais. De maneira geral, essas formas visam reduzir a flutuação dos investimentos sonoros sobre o código verbal. Além do nível fonético, os sons são traduzidos seja como marcas dos usos relativos aos segmentos sociais, seja como marcas idiossincráticas. Para tanto, há primeiramente um tratamento fonético e, em seguida, um fonológico, de modo que as qualidades pessoais da voz sejam observáveis a partir desses primeiros investimentos fonéticos, promovendo então outros níveis de análise, chamados de suprasegmental e paralinguístico.

Com isso, a voz pode ser identificada com o resíduo da análise do signo linguístico passível de outras análises, posicionada junto à neutralização das unidades fonológicas. Ao mesmo tempo em que proporciona efeitos conotativos, a atividade composicional do falante representa a flexibilidade do sistema linguístico nos seus usos, garantindo a significação por meio da linguagem verbal. Em outras palavras, a voz é depreendida como uma continuidade determinada pelas ocorrências das unidades linguísticas, mas pode também ser tomada como uma substância condicionada por suas próprias constâncias. 
Isto é, a fonoestilística, tendo se dedicado às marcas pessoais da língua materna, caracteriza o sujeito da fala por seus sinais voluntários e por índices involuntários. De um lado, essas marcas são consideradas endógenas (passionais). De outro, eles refletem motivações exógenas (socioletais, situacionais e profissionais). A partir dessa classificação, os conteúdos são aglutinados como um acompanhamento ou, simplesmente, indexados ao signo linguístico. (LÉON, 1993: 13)

De fato, quando nos lançamos à percepção da esfera acústica, avaliamos a voz nas resultantes fonéticas, manifestadas em nível suprassegmental. Mas, ao questionarmos sobre as dependências internas desse objeto, o uso da voz nas práticas teatrais deve avaliar as especificidades desse sistema, pois a relação de determinação entre a voz e as palavras pode ser revisitada, tendo em vista que a entoação é constitutiva do enunciado das personagens encenadas.

\subsection{Das categorias impressionistas}

$\mathrm{Na}$ apreensão da voz como substância fônica, predicados qualificam essa substância. Basicamente, suas qualidades são divididas entre as intermediadas pelo produtor e as presumidas por um perceptor dos sons. De um lado, o aparato fisiológico ou, simplesmente, o corpo carrega as qualidades vocais por ele produzidas. De outro lado, as impressões geradas são ressaltadas pelo ouvido interpretante.

A indissociação da esfera acústica e dessa percepção faz com que os estudos da entoação sejam perpassados pelas categorias impressionistas. Essas são consideradas ambíguas e, para garantir a univocidade das suposições perceptivas, a segmentação do nível acústico passa por diferentes atribuições de funções em relação ao que é dito. Quer dizer, para validar a percepção, as formas reduzidas da entoação são comprovadas pelas técnicas experimentais e indutivas que, por sua vez, deixam à margem a substância não reduzível. (ROSSI: 1981, 322)

Quando os sons são segmentados por suas propriedades acústicas, o corpo é necessariamente pressuposto para essa descrição. A base corporal torna-se especialmente relevante para detalhar os caracteres da tessitura e do registro fonatório. 
Evidentemente, há uma extensa discussão sobre o uso preciso desses conceitos e sobre as condições fisiológicas apresentadas para que essas qualidades sejam emitidas.

Sintetizamos a listagem dessas qualidades "fenomenológicas" reunidas por Parret (2002: 41 - 45), procurando o predicado que subsumiria as variações como, por exemplo, "sombrio, sepulcral e pálido", compreendidos pela aplicação da analogia como uma graduação da luminosidade. É possível observar os três níveis dessas qualidades que, por sua vez, são apresentadas em duas esferas, a saber, a da voz e a do ouvido, conforme elas seguem abaixo.

\begin{tabular}{|c|c|}
\hline Voz (segmentação acústica) & Ouvido (qualidades das impressões) \\
\hline Tessitura e tonalidade & Cor; luminosidade; peso; profundidade; \\
\hline Volume & Grandeza; textura; \\
\hline Tempo & Velocidade; peso \\
\hline Continuidade & Fluxo \\
\hline Registro fonatório & Timbre; fisionomia \\
\hline \multicolumn{2}{|l|}{ Corpo (fisiologia da produção) } \\
\hline Localização & Abertura; fechamento; extensão \\
\hline Tensão muscular & Textura; \\
\hline Modo de vibração das cordas & Textura; fisionomia \\
\hline
\end{tabular}

Convém ressaltar que os adjetivos impressionistas regidos pelas emoções como, por exemplo, "o monótono e o dolente", reaparecem seja qual for a proposta de segmentação da sonoridade. Outro aspecto relevante acerca dessas categorias é que quanto mais nos aproximamos das impressões reconhecidas como uma trama ou como um agrupamento (por exemplo, a textura áspera e a lisa), mais essas características surgem ao lado de traços fisionômicos que, por sua vez, são separáveis ora pelo tipo físico (o gordo e o magro), ora pela personalidade (o rude e o delicado). 
A partir da experiência perceptiva da audição, somos levados a crer que essas categorias impressionistas não se excluem mutuamente, mas manifestam-se em constante solidariedade, sobrepondo-se e justapondo-se. Essa simultaneidade, configurada numa sucessão, promove uma sintaxe cujas posições são negociadas entre as grandezas representadas pelo nível acústico da substância fônica. Do mesmo modo, encontramos em Hjelmslev a separação desses níveis da substância e a tentativa de compreender esses níveis como reciprocamente solidários (HJELMSLEV, 1991: 71).

Sabe-se que a substância fônica, considerada em seu conjunto e no sentido mais amplo do termo, exige uma descrição fisiológica (também chamada articulatória, miocinética, etc.) e uma descrição puramente física (ou acústica, no sentido próprio deste termo), e que talvez seja preciso acrescentar auditiva, segundo a percepção dos sons da linguagem pelos sujeitos falantes. (HJELMSLEV, 1991: 62)

Em linhas gerais, para o presente estudo dos usos da voz no teatro, consideramos que a síntese das impressões é mais relevante do que a procura das formas reduzidas pelos experimentos direcionados ao interesse estatístico. Isto é, acreditamos que o sistema subjacente à entoação teatral possa ser resultado de uma reflexão sobre as relações entre os sons, estabelecidas pelos discursos presentes quando de um corpus em questão.

Assim, como um dos primeiros procedimentos de análise, as categorias subordinadas pelas impressões auditivas alcançam uma espécie de descrição que, modalizada pela atenção do analista, não pode ainda ser considerada a explicação dos mecanismos que regulam essa linguagem. Em outras palavras, na correspondência entre a segmentação acústica e as categorias impressionistas, a análise descritiva pode cair na tentação de atribuir autossuficiência desse sistema à relação entre a natureza física dos sons e as suas consequentes impressões pré-formais, o que transformaria essa abordagem em proposta orientada para uma dada realidade no interior do campo da análise semiótica.

Diante disso, a observação dos parâmetros acústicos (intensidade, duração e altura) possibilita o primeiro contato com essa manifestação, em relação a qual a 
metalinguagem descritiva acaba por predicar as redes discursivas da modulação vocal. Essa etapa descritiva visa um segundo momento, que pode ser chamado de adequação às categorias previstas pelo modelo tensivo, ou de conversão ao sistema imanente (ZILBERBERG, 2006 b: 131). Acreditamos, com isso, que os discursos da entoação apresentem as cargas tensivas voltadas progressivamente à sintaxe de suas grandezas.

\subsection{As sonoridades como um conjunto significante}

Do ponto de vista teórico, nossa perspectiva pretende se deter na especificidade da semiótica teatral, pois, no teatro, a maneira de dizer torna-se tão relevante quanto aquilo que é dito. Quer dizer, no teatro, o enunciado não está somente exposto e suplementado pela dimensão sonora, mas, ao contrário, é constituído também por ela. Sem o papel constitutivo da entoação, o espetáculo talvez nem pudesse ser compreendido. De fato, os elementos sensíveis participam de maneira central na inteligibilidade da encenação, à medida que os afetos anunciados pelas entoações transformam-se em informação pertinente para o entendimento da audiência.

Entre os inúmeros exemplos relativos a essa característica da semiótica teatral, duas teorias da prática teatral, consideradas praticamente como antagônicas, a de Artaud e a de Stanislavisky, ilustram como os sons da fala teatral privilegiam certa musicalidade e, consequentemente, uma determinada organização das sonoridades. $\mathrm{Na}$ proposta radical de Artaud (1999), o ator teatral busca por ápices e modulações em seu exercício vocal, de modo que esses fluxos sonoros gerem ora o impacto, ora o conforto dos ouvintes. Na proposta comumente chamada de realista e naturalista, o exercício da atuação é promovido no entorno das intenções do sujeito enunciativo, gerando modulações variadas. Segundo Stanislavisky (1984), um ator da grande escola russa pode encontrar ao menos quarenta maneiras de dizer uma ou duas palavras, configurando um repertório de escolhas que alteram completamente a construção de suas personagens, o jogo de cena em que um caráter é posicionado, e, logo, a compreensibilidade global do espetáculo. 
A partir disso, reconhecendo a potência semiótica da entoação, torna-se necessário refletir sobre essas configurações discursivas e a geração de seus conteúdos. Assim, aceitamos:

(...) vem do estatuto ambíguo dessas unidades, que são ao mesmo tempo articulações reconhecíveis do plano da expressão (por exemplo: curva ascendente / curva descendente) e articulações do plano do conteúdo de valor gramatical (suspensão / conclusão), isto é, como morfemas de tipo particular que organizam a sintagmática linguística no nível dos signos, os quais dependem de um princípio de articulação completamente diferente. Compreendem-se, a partir daí, por exemplo, as razões que levam a semiótica teatral a considerar a dimensão prosódica um significante autônomo, distinto do significante verbal do texto teatral. (GREIMAS e COURTÉS, 2008: 165).

Para descrever os discursos da entoação, procuramos a combinatória entre os componentes dessa articulação (ascendência, descendência), à qual pode ser acrescida de um terceiro, localizado na permanência sobre um mesmo tom. Nas palavras de Luiz Tatit: "Uma voz que busca a frequência aguda ou sustenta sua altura, mantendo a tensão do esforço fisiológico, surge sempre em continuidade (no sentido de prossecução)." (TATIT, 1996: 21).

Com a sintagmatização desses componentes, outras categorias são convocadas como, por exemplo, a aspectualização. Assim, a ascendência da curva entoativa pode surgir tanto em seu aspecto incoativo quanto em sua duração, de acordo com as reiterações determinantes. Logo, o plano da expressão das sonoridades vocais realizase por meio de uma sintaxe própria da ação vocal que, doravante, pode ser observada a partir de seu programa narrativo. Assim, compreendemos a narratividade, tal qual explicitada por Claude Zilberberg.

A narratividade surge como instância modal "interestratos", na medida em que foi depreendida de seus formantes habituais e, em primeiro lugar, da grandeza das grandezas. Do ponto de vista estrutural stricto sensu, esse estatuto de constante geral (e incondicionada?) explica que a narratividade possa ser concentrada em um lexema, tal como Greimas muitas vezes indicou, ou 
desdobrada por sobre uma grande extensão discursiva. Em ambos os casos, será sempre catalisável. (ZILBERBERG, 2006 b: 121-122)

Assim, quanto mais nos aproximamos das qualidades abstratas relativas aos conteúdos mobilizados pelo substrato da expressão, mais nos coadunamos com o estudo das tensões e dos repousos presentes na semiótica tensiva. Vislumbrando uma hierarquia regente do comportamento vocal realizada pelos atores teatrais, consideramos a semiótica tensiva como uma metassemiótica para explicitar o funcionamento da linguagem que visa a ser descrita.

\subsection{Breviário da tensão}

Para introduzir os elementos da semiótica tensiva, precisamos traçar breve história do conceito tensividade e, em seguida, considerar seus aspectos sintáxicos. Isso nos servirá de preparação para a etapa de aplicação da semiótica, na qual os textos entoados serão explicitados por meio das categorias tensivas então convocadas.

Em seu traçado diacrônico, a noção de tensividade fórica é um pressuposto necessário para o entendimento da obra Semiótica das Paixões (1993), especialmente em seu capítulo introdutório dedicado à epistemologia das paixões, inaugurando novos modelos de previsibilidade para os conteúdos passionais. Incluída como parte da instância modal da semiótica narrativa, a dimensão tensiva surge com o objetivo de representar a carga patêmica das figuras passionais.

Em seu fundamento sintáxico, a semiótica tensiva opera a partir das vicissitudes de um estado e de sua transformação em acontecimento, priorizando a concessão (embora isso, entretanto aquilo) em vez da sintaxe implicativa (se isso, então aquilo). Para a compreensão da tensão, a lógica do acontecimento integra o nível da sintaxe fundamental, de modo que a exclamação (no plano da expressão) possa ser vista como acontecimento (no plano do conteúdo). No momento em que Zilberberg (2006 a) defende a "centralidade do acontecimento" como um dos fundamentos da gramática tensiva, é interessante notar sua pequena menção à expressão teatral: “(...) à savoir que l'événement dans le plan du contenu, la théâtralité dans le plan de l'expression sont, à 
côté du récit et du "schéma narratif canonique", l'une des avenues possible du sens." (ZILBERBERG, 2006 a: 144) ${ }^{14}$

Assim, o plano de expressão anuncia os princípios de formação do sentido, na mesma medida em que a morfologia da sílaba e o papel funcional do núcleo acentual podem ocupar a base do percurso gerativo do sentido. $\mathrm{O}$ acento possui características formais nos dois planos seja como suplemento dos fenômenos sensíveis, seja como unidade apreendida pela afetividade. Zilberberg enfatiza: "La problématique de l'accent est du ressort du plan du contenu; elle est de droit si la perspective est celle d'une prosodisation du contenu (...)" (ZILBERBERG, 2006 a: 100) ${ }^{15}$

Desse modo, é importante notar que pretendemos diferenciar uma descrição impressionista da sonoridade daquela trazida pelo aporte teórico da semiótica tensiva. Ao acreditar que a melodia da fala teatral remete à dimensão tensiva do sentido, não concebemos a tensividade como algo equivalente à modulação entoativa e suas temporalidades intrínsecas. Pensamos que essa possível equivalência decorre da vizinhança entre duas metalinguagens, uma que descreve as sonoridades e outra que, por sua vez, explica o fenômeno da linguagem pela dedução de suas leis condicionantes. Tomando uma etapa de análise pela outra ou, simplesmente, acreditando que a descrição das sonoridades possa ser suficiente para a compreensão de seus sentidos, correríamos o risco de distorcer a teoria, já que ela trata não somente de objetos sonoros e não-verbais, mas de objetos em expressões diversas.

Procuramos assim enfatizar que nosso objeto não se apresenta tal qual uma natureza dada, plenamente observável em sua materialidade expressiva. Em outros termos, não podemos considerar a conformidade entre os planos da expressão e do conteúdo, embora sua copresença e sua coocorrência façam com que essa conformidade esteja circunscrita no vaivém dos procedimentos de análise que revelam as identidades discretizadas. Desse modo, é possível compreender como uma premissa para nossas análises a proposta tensiva sintetizada por Luiz Tatit.

\footnotetext{
14 “(...) à saber que o acontecimento no plano do conteúdo, a teatralidade no plano da expressão são, ao lado da narrativa e do "esquema narrativo canônico", um dos porvir do sentido"(Tradução nossa)

15 "A problemática do acento concerne ao conteúdo, ela é de direito se a perspectiva é aquela de uma prosodização do conteúdo" (tradução nossa)
} 
O plano da expressão que interessa à semiótica não é mais, evidentemente, aquele que tratava das oposições fonológicas ou das realizações fonéticas. Nada tem a ver também com a crença de que o som funcionaria como a materialização direta ou como representação auditiva do continuum fórico, de modo que a descrição sonora pudesse parafrasear a descrição do sentido. O plano da expressão pertinente, nessa fase de pesquisa em que o objeto descritivo possui a dimensão do discurso e seus elementos articulam-se na extensão sintagmática, é aquele que compreende as leis rítmicas da silabação. (TATIT, 2008: $18-19)$

Em suma, diante das diversas qualidades da voz, apontadas por diferentes abordagens (PARRET, 2002), estabelecemos nossos critérios junto ao modelo tensivo de análise. Ao mesmo tempo, as apreensões possíveis da voz declinam-se nos modos pelos quais a metodologia a transfiguraria. Assim, para compreender suas configurações no interior dos discursos proferidos, é necessário abordá-las não como evidência natural, mas sim como um construto teórico. Desse modo, podemos compreender que a voz humana, como produção do falante, é, ao mesmo tempo, um merisma substancial da segmentação linguística e também objeto abstrato do tratamento formal.

Na relação entre o som e o ouvido, a complexidade da composição sonora recai sobre a imponderabilidade de uma personalidade e na incerteza do que podemos afirmar sobre isso. Não é possível esgotar seu sentido na descrição de sua materialidade bruta e na equivalência entre essas unidades e suas informações arbitrariamente selecionadas por um analista. $\mathrm{Na}$ continuidade do projeto estrutural, inversamente, damos atenção às estruturas como imanentes às configurações discursivas.

A utilização da ferramenta metodológica semiótica, segundo nosso ponto de vista, é a única via realmente fecunda para a análise dos processos de significação das encenações teatrais, sobretudo no que tange a sua dimensão sonora ou vocal. A especificidade de nossa análise permite assim notar que uma inadequada compreensão 
da natureza do método implica como seu correlato igual incapacidade de compreensão da potência explicativa das categorias semióticas.

É importante, assim, destacarmos os aspectos do método semiótico que se demonstram particularmente relevantes ao objeto de nosso estudo. Considerando que não podemos prescindir da materialidade da expressão nem do desempenho do corpo e da voz dos atores em cena, daremos prioridade às categorias tensivas, as únicas na semiótica atual que oferecem os mesmos parâmetros descritivos tanto para a análise do plano da expressão quanto do plano do conteúdo. Em outras palavras, a contração ou a expansão dos corpos e das vozes nas cenas, seus pontos de tonificação ou atonização, suas variações de velocidade podem representar situações de conteúdo que, como tais, também se projetam num campo de extensidade e também recebem diferentes cargas intensivas. Sendo assim, julgamos que as descrições das sonoridades da fala e de sua produção de sentido, a partir do modelo tensivo, encontram um terreno plenamente favorável para o desenvolvimento de uma semiótica do teatro. 


\section{Apresentação do corpus de análise}

O corpus é constituído a partir da seleção de trechos das encenações de Medeia de Antunes Filho, reconhecido diretor paulista. No CPT (Centro de Pesquisas Teatrais) do SESC, três tragédias gregas foram realizadas em quatro concepções: Fragmentos Troianos (1999), uma adaptação de As Troianas de Eurípides; Medeia (2001), Medeia 2 (2003), de Eurípides, e, por fim, Antígona de Sófocles (2005).

Antunes Filho pode ser visto como parte da história do teatro brasileiro na procura de sua identidade. Foi reconhecido, em 1958, por críticos como Bárbara Heliodora e Décio de Almeida Prado, como importante novo encenador teatral, após um período de influências europeias, que marcaram a criação do TBC (Teatro Brasileiro de Comédia), criado em 1948. Transitando por diferentes propostas de linguagens da encenação, do "realismo cinematográfico" ao distanciamento épico, esse encenador explorou as colorações naturalistas e expressionistas (MILARÉ, 2007:63).

Na passagem da primeira metade para a segunda do século XX, Antunes é um dos entusiastas da escritura cênica e do olhar sobre o trabalho do ator. No período em que consolidava seu reconhecimento pelo público, encabeçando o grupo Macunaíma, o teatro refletia os ecos modernistas. Essa necessidade tangenciava tanto o conteúdo ideológico das manifestações, como no teatro de Arena (1953), quanto o experimentalismo diante da fala e do corpo brasileiros, que se sobrepusesse à simples adaptação estética dos achados importados. Desde 1982, Antunes tem sua sede numa das unidades do SESC. No CPT (Centro de Pesquisas Teatrais). Nesse ciclo de tragédias, é possível observar a atenção especial aos usos da voz, que em um de seus limites torna-se um instrumento.

A gravação integral dos espetáculos foi disponibilizada pelo diretor e sua equipe somente para pesquisas e trabalhos acadêmicos. A edição das cenas é encontrada em: http://vimeo.com/27693293/, com o material das três primeiras análises. Em 
http://vimeo.com/29893306, consta a cena da última análise. Acessando esses endereços, um password será solicitado. A senha que deve ser colocada é esta: medeiaCPT12 (respeitando a caixa alta nos caracteres).

Selecionamos três episódios em que a heroína é configurada, procurando as nuances da entoação na personagem central. Na primeira cena, ela é apresentada dando início à ação. Esta cena é dividida em dois excertos, pois há uma fala do coro, intercalando as da personagem central, que não foi contemplada. Na segunda cena analisada, ela está em embate com Jasão. Na terceira, ela dissimula sua motivação, também em confronto com Jasão. A quarta e última análise incide sobre uma cena em que personagem coral nas encenações de Medeia desempenha um papel importante na culminância da tensão do drama. Sendo assim, a comparação entre as encenações de Medeia explicita uma prerrogativa da análise: as possíveis diferenças entre propostas e concepções de montagem da obra dramatúrgica que se deixam ver por meio dos usos da voz.

As cenas selecionadas são encontradas destacadas no quadro abaixo.

\begin{tabular}{|c|c|c|c|}
\hline $\begin{array}{l}\text { 1) Os antecedes da } \\
\text { ação: a traição de } \\
\text { Jasão e a ira de } \\
\text { Medeia }\end{array}$ & $\begin{array}{l}\text { 2) A extrusão de } \\
\text { Medeia de } \\
\text { Corinto }\end{array}$ & $\begin{array}{l}\text { 3) A compreensão do } \\
\text { estado de Medeia }\end{array}$ & $\begin{array}{l}\text { 4) O embate entre } \\
\text { Medeia e Jasão }\end{array}$ \\
\hline $\begin{array}{c}\text { Ama } \\
\text { Preceptor } \\
\text { Coro } \\
\text { Medeia }\end{array}$ & $\begin{array}{l}\text { Medeia } \\
\text { Creonte }\end{array}$ & $\begin{array}{c}\text { Medeia } \\
\text { Coro }\end{array}$ & $\begin{array}{c}\text { Medeia } \\
\text { Jasão }\end{array}$ \\
\hline $\begin{array}{l}\text { 5) Uma oraçãa à } \\
\text { Afrodite }\end{array}$ & $\begin{array}{l}\text { 6) A promessa de } \\
\text { asilo em Atenas }\end{array}$ & $\begin{array}{l}\text { 7) Os planos de } \\
\text { Medeia }\end{array}$ & 8) A dissimulação \\
\hline Coro & $\begin{array}{r}\text { Medeia } \\
\text { Egeu }\end{array}$ & $\begin{array}{c}\text { Medeia } \\
\text { Coro } \\
\text { Ama }\end{array}$ & $\begin{array}{c}\text { Medeia } \\
\text { Jasão }\end{array}$ \\
\hline
\end{tabular}




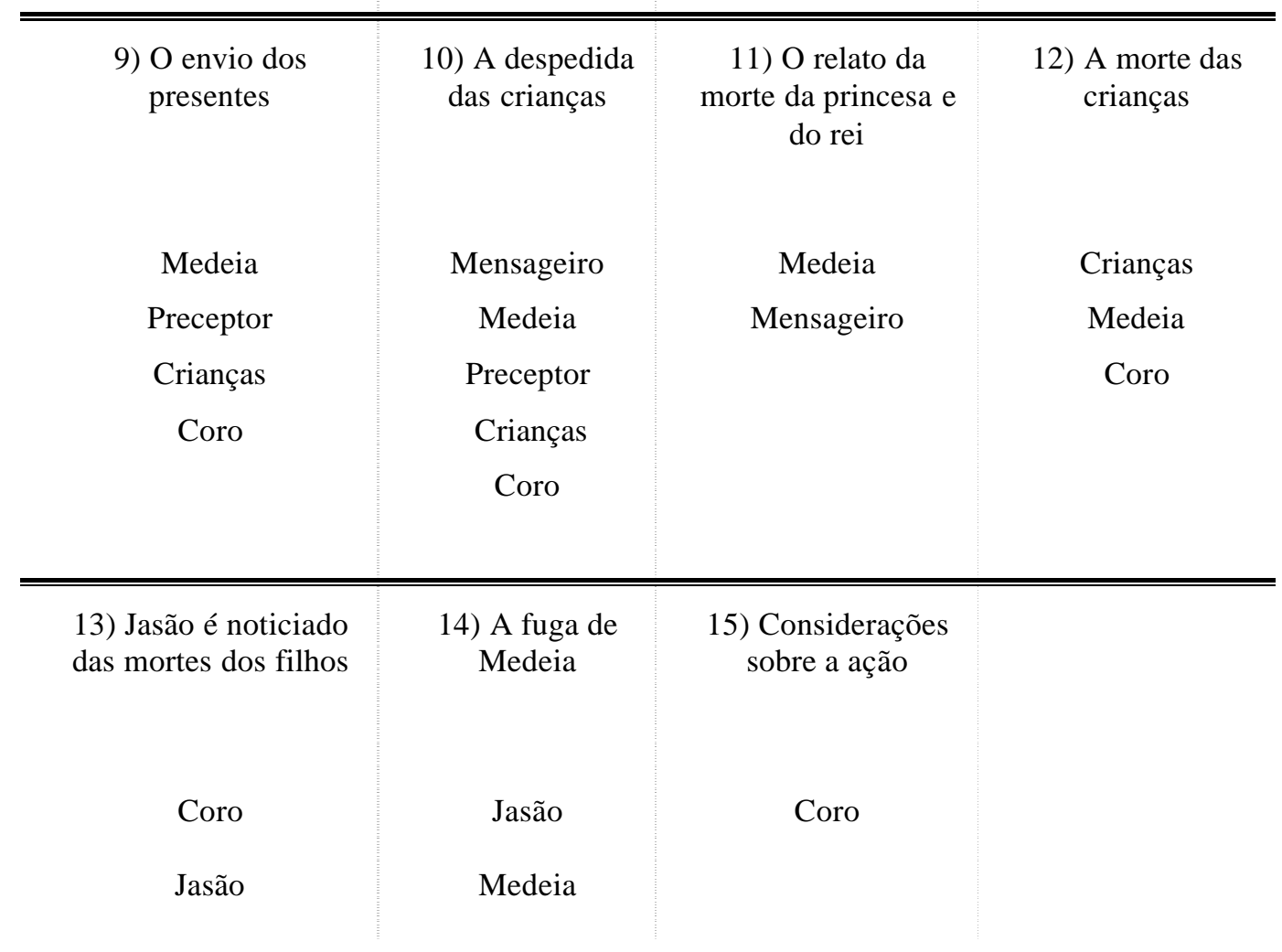

Nas páginas seguintes, a representação abaixo possibilita visualizar os procedimentos vocais contemplados, tendo como finalidade esquematizar seus processos discursivos em linhas amplas e gerais. Essa representação atuou, sobretudo, na gestão interna da nossa abordagem, para que não nos esquecêssemos da multiplicidade no material em análise, a voz humana. Desse modo, supomos ser proveitosa a reflexão sobre os possíveis meios de anotar algumas ações vocais sobre um mesmo texto escrito. A imagem permite a extração dos acontecimentos regulares, explicitando mais claramente a organização de uma escritura cênica ou de uma partitura subjacente.

Ao propormos determinados grafismos, buscamos expor certos movimentos da dinâmica vocal que nos parecem pertinentes para a análise, em detrimento de outros. Tal escolha não se fez por simples arbitrariedade do analista, mas por considerar que alguns procedimentos podem e devem ser privilegiados, figurando como protagonistas. Um exemplo poderia ser dado pela descrição da mudança de registro, 
apresentado pelo caráter lamentoso em Medeia 2, a qual pode ser contemplada na sua interação com a tonificação, na medida em que a força do volume convergiria muitas vezes para o agravamento.

Com isso, não pretendemos esgotar todas as possibilidades de relação entre esquema e apreensão. O esquema, entendido como uma partitura, ou como a estabilização alcançada pelas formas delineadas, é tanto a particularização das possibilidades descritivas diante da escuta, quanto o esboço para geração de outros contrastes. Nesse ponto, ao passo que nossos traços procuravam mimetizar alguns percursos da voz, desvelavam-se seus rastros somente percebidos quando nos atemos às construções sobre sua paisagem neutralizada.

Legenda:

- Melodia (espectro de tons ou alturas) - tonificação.

$\mathrm{x}^{\mathrm{x}}$ (sobrescrito) - acento tonal ascendente

$\mathrm{X}_{\mathrm{X}}$ (subscrito) - acento tonal descendente

- Ritmo (acentuação e duração) - tonicidade e temporalidade.

x (fonte sem alteração) - breve

$\mathrm{X}$ (aumento da fonte) - longa

/ (barra diagonal) - pausa

// (dupla barra) - acentuação da pausa

$\sim($ acento tio $)$ - antecipação - aproximação

$\wedge$ (acento circunflexo) - atrasos - afastamento

- Dinâmica - tonificação.

$\mathrm{x}$ (itálico) diminuindo

$\mathrm{x}$ (negrito) crescendo

- Andamento 
x (pontilhado) - desaceleração

$\underline{x}$ (sublinhado) - aceleração.

$\underline{\underline{x}}($ duplo sublinhado $)$ - mais aceleração

3.1 Da primeira análise (apresentação da personagem)

Primeiro excerto - Medeia 1 (7'48', - 8'52',)

Pobre// bem pobre mulher ${ }^{\text {sou } / \text { Pobre querido }}{ }^{\text {pai } / \text { Pobre querida }}{ }^{\text {te }}$ rra/ pobre querido

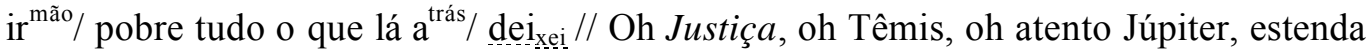
seus poderosos braços de fogo e transforme em brasas vivas o tratante Jasão, junto com a princesa $/ \wedge$ e também o rei/ com suas riquezas bosques e castelos/ Que essa voragem transforme em labaredas tenebrosas / e que das cinzas o vento cuide depois, arrogando as para o fundo do ${ }^{\text {INFERNo. }}$

Segundo excerto - Medeia 1 (9' - 10'33'')

Accalmmar-me. Isso é fácil de falar./ Palavras podeis até cantar e dançar./ $\sim \mathbf{E} \mathbf{e u} ? / \sim \underline{\text { Eu}}$ nesse estado de absoluto abandono que me encontro./ $\wedge$ Então, onde estão as leis superiores, ${ }^{\text {onde ficam as promessas }}$ e os ${ }^{\text {tratos sagrados}}$ ? VÓS! Vós tendes essa terra natal, o protegido e aquecido lar paterno, a companhia e a amizade de outras mulheres./ $\mathbf{E}$ EU? O QUE TENHO?/ O que me rest $^{\text {ou }}$ ? $\underline{\text { Sou uma desterrada em terras }}$ estrangeiras,/ sofrendo injustas afrontas de um marido que me seduziu / me arrancou da minha pátria e do meu lar./ Não tenho pai, mãe, irmão, / nenhum parente que possa me proteger dessa humilhante traição de que fui vítima./ Ah. Pudesse eu, pudesse alguma de vós/ em algum meio, algum plano para vingar-me de todas essas vilanias e humilhações que me impuseram./ Tanto o tratante de meu marido, como o rei e sua filha que bem souberam negociar esse indigno matrimonio/ Todos eles por 
Têmis e Júpiter devem pagar por esse tão alto insulto. QUE VENHA, POIS, SEM TARDAR A JUSTIÇA!

Primeiro excerto - Medeia 2 (5',27', - 6' 02',)

Pobre / bem pobre mulher sou, pobre querido pai, pobre querida terra, pobre querido ir mão. Pobre tudo que lá atrás // deixei / Oh justiça, oh Têmis, oh atento Júpiter / estenda seus poderosos braços de fogo / e transforme em brasas vivas o tratante Jasão / junto com a princesa e também o rei / com suas riquezas, terras, bosques e castelos / que essa voragem transforme tudo em labaredas tenebrosas $e$ que das cinzas $o$ vento cuide depois / arrogando - as para o fundo do inferno

Segundo excerto - Medeia 2 (6'09', -7' 32',)

Acal $^{\text {mar }}$-me. Isso é fácil falar. Palavras / podeis até cantar e dançar. E eu? // // Eu aqui neste estado de absoluto abandono em que me encontro. Então,/ onde estão as leis superiores, onde ficam as promessas e os tratos sagrados? Vós! Vós tendes essa terra natal, o protegido e aquecido lar paterno/ a companhia e a amizade de outras mulheres. Mas, e eu? O que tenho? O que me restou? / Sou uma desterrada em terras estrangeiras, sofrendo injustas afrontas de um marido que me seduziu e arrancou-me da minha ${ }^{p a ́}$ tria e do meu lar. Não tenho pai, mãe, irmão, nenhum parente que possa me defender desta / humilhante traição de que fui vítima. Ah. $\sim$ Pudesse eu, pudesse alguma de ${ }^{\text {vós }}$, qualquer uma,/ socorrer-me com algum meio,/ algum plano para vingar-me de todas essas vilanias e humilhações que me impuseram. Tanto o tratante de meu marido, como o rei e sua filha que bem souberam negociar esse indigno matrimônio. Todos eles por Têmis e Jupiter devem pagar por esse tão alto insulto. Que venha, pois, sem tardar Justiça!

3.2 Da segunda análise (o embate com Jasão) 
Medeia 1 (20' 40', - 24' 16'')

MONSTRO / MONSTRO / Essa imagem que tenho / vendo-te tagarelar tãa tranquilamente na minha frente / Não é a estatura moral, nem autoconfiante que te coloques nesse ${ }^{\text {pedestal }}$ onde imaginas que estás. $\sim$ Ao contrário é generosidade arrogante e o mais infame defeito humano a insidiosa hipocrisia / ${ }^{\mathrm{AH}}$ como isso me ofende, isso /me agride, mas também não somente a mim, mas também a todos os homens e também a todos os DEUses/ que não deixam de testemunhar/ as tuas acões / monstro // Contudo não foi inútil a sua vinda/ poderás ouvir a viva voz com os teus dois ouvidos /to-das as ingra-tidões com ora que me re-com-pensas/ Por tudo aquilo que $\underline{\text { fiz/ }} \sim$ Te SALVEI/ como sabem todos os gregos que estavam contigo na nave Argos/ quando matei o terrível dragão que guardava o teu cobiçado, conquistado apesar de tantos obstáculos/ velocino de ouro de / e depois eu mesma/ traindo meu pai e minha família/ para te seguir/ Sacrifiquei o meu irmão/ Absirto pois não podia deixar de preservar a vida do meu esposo/ e em Ouco/ antes com mais pressa do que com prudência/ livrei-te de todas as ameaças do rei Pélias/ persuadindo as filhas a matarem cruelmente o próprón pail que outro tantos fatos/ preciso acrescentar/ para provar a

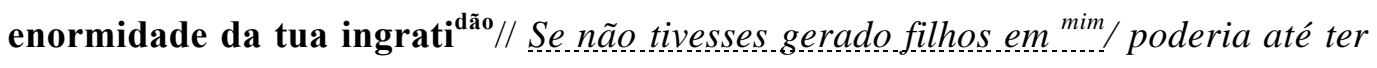
uma desculpa esfarrapada para ir correndo ao novo leito/ seria um ótimo pretexto para ir mantendo sua nobre linhagem / És monstro/ um fingido $\sim$ tuas palavras $\sim$ teus juramentos / nada valem / Crês que o que os deuses já não valem /ou que os céus decretaram novas leis $/ /{ }^{\mathrm{AH}} / / \wedge \mathrm{A}$ mão direita que apertastes entre as duas mãos tantas e tantas vezes / a em joelhos, joelhos que foram tocados por pérfido suplicante /

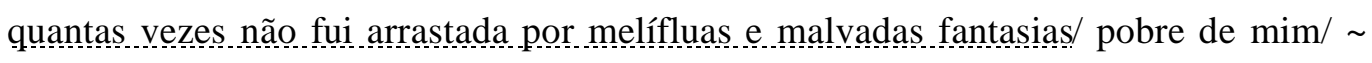
Mas e agora o que faço/ para onde devo ir/ supondo que ainda seja por um só momento / realmente o meu amigo/o que me aconselharia/ PARA ONDE DEVO $\mathrm{IR} / \sim$ quem me acolher ${ }^{\mathrm{ia}} /$ aqueles que não tive necessidade de prejudicar ou injuriar/ tornei meus inimigos por tua causa // Enfim / estouperdida_ / aqui / acolá / no mundo / sem amigos e sozinha / Vivas portanto oh valorosos noivo que garbosamente abandona pelas estradas como mendigos a mulher e os filhos 
Medeia 2 (16'25', - 19'37'')

monstro/ monstro. Essa imagem que tenho vendo-te tagarelar tão tranquilamente na minha frente/ Não é estatura moral, nem autoconfiança que te colocas nesse tão alto

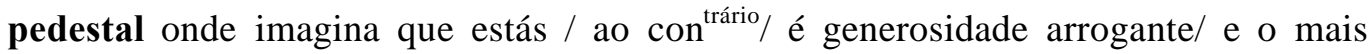
infame defeito humano a insidiosa hipocrisia.// Isso / me ofende isso me agride / não somente a mim, mas também a tọdos. os homens e também a todos os deuses que não deixam de testemunhar as tuas ações. MONSTRO. / Contudo/ não foi inútil a tua vinda/ poderá ouvir a viva voz com os teus dois ouvidos todas as ingratidões com que ora me recompensas, por tudo aquilo que te fiz.// Te salvei, como sabem todos os gregos que estavam contigo na nave Argos, quando matei o terrível dragão que guardava o teu / cobiçado, conquistado apesar de tantos obstáculos velocino de ouro e depois / eu mesma / traindo o meu pai e minha família/ para te seguir, sacrifiquei o meu irmão Absirto pois / não podia deixar de preservar a vida do meu esposo e em Ouco antes com mais pressa do que com prudência, livrei-te de todas as ameaças do rei Pélias, persuadindo as filhas a matarem cruelmente o próprio pai / que outros ${ }^{\text {tantos }}$ fatos preciso acrescentar para ${ }^{\text {provar }}$ a enormidade da tua ingratidão./ Se não tivesses gerado $^{\text {filhos }}$ em mim poderia até ter uma desculpa esfarrapada para ires correndo ao novo leito./ Seria um ótimo pretexto para ires manter sua ${ }_{\text {nobre }}{ }^{\text {linhagem }}$./ És monstro, um fingido, tuas palavras teus juramentos nada valem./ Crês que os deuses de então já não reinam / ou que os céus decretaram novas leis. / ${ }^{\text {A mão direita }}$ que ${ }^{\text {apertastes entre }}$ as tuas mãos tantas e tantas vezes. Ah, joelhos joelhos que em vão foram tocados por pérfido suplicante quantas vezes não fui arrastada por melífluas e malvadas fantasias, pobre de

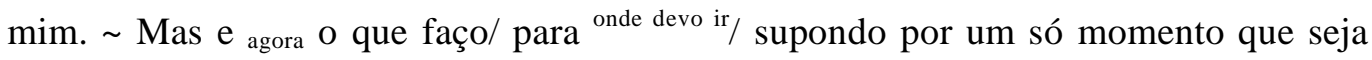
que fosses / realmente o meu amigo/o que me $\operatorname{acon}^{\text {selharia } / \sim \text { para }}{ }^{\text {onde }}$ devo ${ }^{\mathrm{ir}} / \sim$ quem me acolheria / aqueles que não tive necessidade de / prejudicar ou injuriar/ tornei / meus inimigos por tua causa // enfim / estou perdida / aqui / acolá no mundo / sem amigos e sozinha / vivas vivas portanto oh valorosos noivo que garbosamente abandona pelas estradas como / ${ }^{\text {mendigos }}$ mulher e filhos 


\subsection{Da terceira análise (a dissimulação)}

\section{Medeia 1 (41' - 42'18'')}

PErdoa - me ${ }^{\text {Jasão }}$ ? Peço-te indunlgệncịa por tudo aquilo que disse. ${ }^{\text {Perdoa }}{ }^{-m e}$ os meus arrebatamentos quase sempre desvairados compensando-os generosamente se possível ${ }^{\wedge} \wedge$ as provas de afetos que no passado sempre e que de maneira ou de outra procurei lhe oferecer/ $\sim$ Pensei e pensei, troquei palavras comigo mesma e só então/ me dei conta da grande $\stackrel{\text { injustiça que estava }}{\text { cometendo/ }} \sim$ Desgraçada de si como podes Medéia sustentar tamanha má vontade, tamanha animosidade/, tamanha fúria Contra aqueles que querem real $^{\text {mente }}$ te estender a mão. És cega? És louca_por acaso? ?/ $^{\text {Perdoa }}$-me Jasão de coração. $\mathrm{Eu}$ não tive como em sã consciência rebater aqueles seus arbítrios $\underline{\text { francos, }}$ conscientes, prudentes. $\simeq$ Então, como estive tão contra os governantes de Corinto $\sim \mathrm{e}$

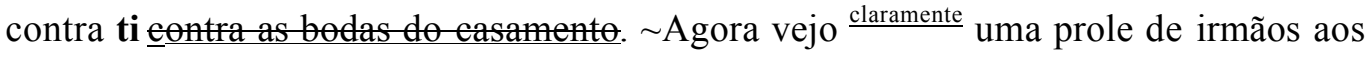
meus filhos, dando-lhes ${ }^{\text {no futuro }}$ segur ${ }^{\text {ança desejada }}$ e também re ${ }^{\text {aleza }}$ Embora, não possas me perdoar, não sei se mesmo eu poderei me perdoar de tão impensadas atitudes. Sempre fui cabeça dura bem sabes.

Medeia 2 (33'30'' - 34'47'')

PerdOa - me Jasão? PeçO- ${ }^{\text {te }}$ indul gência/ por tudo aquilo que disse/PerdOa-me os meus arrebatamentos qua $_{\text {se }}$ sempre/ desvairados. $\sim$ Compensando generosamente/ se possível $/ \sim$ As provas de afetos que no passado $\sim$ sempre/ de uma man ${ }^{\text {eira }}$ ou de outra $_{\text {ta }}$ procu $^{\text {rei }}$ lhe ofere cer Pensei// e pensei, troquei palavras comigo mesma e só então me dei conta da grande injustiça que estava cometendo. Desgraçada de si. Como ${ }^{\text {podes }}$, Medéia, sustentar tamAnha má vontade, tamanha animOsidade, tamanha ${ }^{\text {fúria }}$, contra aqueles que querem REalmente te estender a mãol És cega? I/ És louca por acaso? Perdoa-me Jasão / de coração. Eu não tive como em sã consciência rebater aqueles teus argumentos. $\sim$ Foram de bom senso, prudentes. Então, como estive tão contra os governantes de Corinto e contra ti, que acertas um oportuno casamento, visando/ vejo, 
agora, claramente/ uma prole de irmãos aos meus filhos, dando-lhes no futuro segurança desejada e realeza. / /omo?// Embora, não possas me perdoar, não sei se tão logo eu mesmo poderei me perdoar de tão impensadas atitudes. // Sempre fui cabeça dura, bem sabes.

\subsection{Da quarta análise (os coros)}

\section{Coro da primeira encenação (M1) (39',53"', - 40"38'"')}

Como é que Atenas/ a cidade dos rios sagrados/ um pais que honra seus amigos/ poderá acolher a

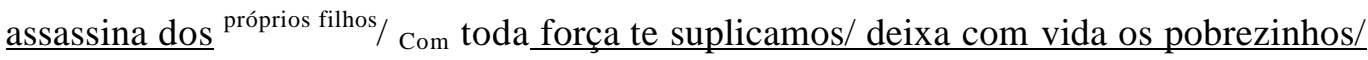
Quando as crianças se ajoelharem suplicantes a tua frente/ não terás coragem suficiente de sujar as mãos com sangue tão inocente/ Ao olhar os olhos dos próprios filhos, não persistirá na impiedosa intenção / Não conseguirás olhá-los e presenciar sem lágrimas / tão profundo martírio// Não pratiques ato tão hediondo em sangue do teu sangue.

Coro da segunda encenação (M2) (32'"29',' - 33',08',')

Como é que Atenas / a cidade dos rios sagrados / o país que honra seus amigos/

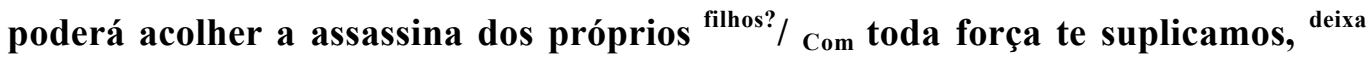
com vida os pobrezinhos/ Quando as crianças se ajoelharem suplicantes a tua frente/ não terás coragem suficiente de manchar as mãos em sangue tão inocente/ Ao olhar os olhos dos próprios filhos, não persistirá na impiedosa intenção/ Não conseguirás olhá-los e presenciar sem lágrimas/ tão profundo martírio/ Não pratiques ato tão hediondo em sangue do teu sangue, Medeia. 


\subsection{Relato do mito}

Medeia era filha de Aétes, rei da Cólquida (localizada na atual Turquia), e neta de Hélio, o Sol. Por isso, ela era considerada uma bárbara, uma estrangeira, e exímia conhecedora de ervas e de feitiços.

Grande parte da história dessa heroína ocorre no entrelaçamento com a de Jasão, um grego da Tessália. Afinal, os dois tornaram-se amantes e cúmplices. Jasão é especialmente reconhecido por suas aventuras de juventude. Ele constrói a nau chamada Argos e reúne os argonautas, uma tripulação de cinquenta e dois homens, partindo em busca do velocino de ouro. Com a conquista do objeto mágico, Jasão retorna a Iolco, a fim de recuperar o trono prometido, mas a posse da coroa que lhe pertence por direito não se torna possível.

O carneiro do tosão de ouro, falante e voador, foi um presente de Hermes à rainha Néfele, primeira mulher do rei de Tebas, trazendo abundância e poder ao seu dono. Em fuga da perseguição pela segunda esposa do rei tebano, o velocino chega à Colquida. Então, ele é sacrificado e mantido aos pés do Monte Cáucaso, estando sob o reinado de Aétes, pai de Medeia. Diferentes tradições afirmam que sua imolação era o cumprimento de uma oferta a deuses diversos. Uma diz que ele é morto em nome de Zeus, outra relata que foi para agradar a Ares.

Chegando a essas terras distantes, o chefe dos Argonautas submete-se a provas impossíveis, em nome da conquista do velocino. Primeiramente, ele enfrenta dois touros terríveis, depois deve ultrapassar o dragão que guardava os pés do Cáucaso, onde estava a pele do carneiro. Jasão conclui a primeira tarefa porque Medeia, apaixonada pelo jovem grego, lhe oferece um bálsamo para proteção de seu corpo, tornando-o insensível às chamas expelidas pelos gigantes taurinos. A feiticeira conhece também a magia para adormecer o dragão e, assim, o casal alcança a conquista.

Tendo em sua posse o tosão encantado, o casal parte para mais uma saga a bordo da nave Argos. Atravessando o Mar Negro, eles chegam à Sardenha. Nessa trajetória, Medeia assassina Absirto, seu irmão que lhes perseguia no encalço do velocino. 
Quando, por fim, a Argos aporta em Iolco, Pélias recebe o tosão, mas recusa-se em respeito ao cumprimento de sua promessa.

O rei usurpador não devolve o trono a Jasão e, além disso, leva à morte Aéson e também Alcimedeia, o pai e a mãe de Jasão. Diante dessas notícias, Medeia resolve cumprir a vingança em nome de seu esposo. Por estranha ilusão, a feiticeira persuade as filhas de Pélias a esquartejá-lo e deitar seus pedaços num cozimento que prometia rejuvenescer o pai então despedaçado. Pélias não ressuscita.

Depois disso, Jasão e Medeia fogem, sendo acolhidos em Corinto, onde vivem harmoniosamente por dez anos. Mas Jasão, cansado de Medeia, procura casar-se com Glaucia, filha de Creonte, rei de Corinto. Jasão imagina finalmente viver na corte. Sofrendo com a traição e o abandono, Medeia vinga-se, matando a princesa, o rei e os próprios filhos. (GUIMARÃES, 1995; EURIPIDES, 1972) 


\section{Medeia a duas vozes}

O mito de Medeia não narra somente o infanticídio ou a culminância numa catástrofe, conforme se apresenta na tragédia de Eurípides. Há também o percurso precedente de uma mulher estrangeira, que se torna companheira de Jasão, o então argonauta em busca do velocino de ouro. A heroína mítica chega ao momento agônico, após a realização de todas as espécies de sacrifícios para que os desejos do amante estivessem satisfeitos. A tragédia de Eurípedes começa a partir de uma notícia de ruptura: Jasão resolve se casar com a princesa de Corinto.

O interesse pela narrativa ou pelo mito ganha outros contornos dentro do espetáculo. A diferença fundamental desse interesse pode ser compreendida a partir da oposição entre os princípios de composição da épica e os da tragédia. Na épica, um aedo ou um rapsodo principiavam a récita como quem toma a palavra usando ele/ lá/ então. No drama, o olhar estava voltado para o que era compreendido como ação, fatos ou atos distribuídos e arranjados, conforme uma mesma unidade espaço-temporal, no momento presente do espetáculo. O teatro era também o lugar para se assistir o que era narrado nos mitos já conhecidos. Com o encadeamento fabular elaborado pelo tragediógrafo, o drama trazia não mais a atenção à narrativa cíclica dos feitos de então, mas procurava perscrutar as motivações da ação trágica no agora. As preocupações desse gênero estão traçadas no excerto da Poética, em que Aristóteles divide as partes da tragédia em: pensamento, caráter, elocução, melopeia e espetáculo.

O pensamento: consiste em poder dizer sobre tal assunto o que lhe é inerente e a esse convém. Na eloquência, o pensamento é regulado pela política e pela oratória. (...) Caráter é o que revela certa decisão ou, em caso de dúvida, o fim preferido ou evitado. (...) Denomino elocução o enunciado dos pensamentos por meio das palavras, enunciado esse que tem a mesma efetividade em verso ou em prosa. (...) A melopeia é o principal ornamento (da linguagem). Quanto ao 
espetáculo cênico, decerto seja o mais emocionante (...) (ARISTÓTELES, 1973: 449)

A partir disso, nos voltamos para as diferenças entre as encenações e para os sentidos gerados por elas. As inscrições sobre os materiais cênicos, quando comparados, divergem como luz e sombra. Esses contrastes podem ser vistos em diferentes planos de expressão da encenação como, por exemplo, no uso das cores, nas escolhas de movimentação pelo palco e do corpo em si. Na primeira encenação, o espetáculo ocorre sobre o fundo branco, enquanto na segunda sobre o negro. Medeia 1 caminha do fundo ao centro do palco, procurando as laterais. Medeia 2 não despende suas forças, contém-se em certa imobilidade. Da mesma maneira, são construídas as dinâmicas na regularidade dos perfis rítmicos e melódicos nas entoações. É possível assim contemplar diferentes construções da personagem delineadas pela ação vocal.

Aprofundamos o estudo da personagem central, pois, como foi possível perceber, nessas concepções das encenações sobre a obra dramática, ela distribui os outros elementos do espetáculo. Supostamente, é fácil imaginar que não há somente essa relação possível entre personagem e cena. Mas, afinal, ao se definir como um caráter regido pela ira, Medeia apresentaria ou não suas modulações em relação às situações de confronto com as circunstâncias e com outros personagens? Caso apresente, de que maneira isso se dá?

\subsection{Precedentes de uma comparação}

$\mathrm{O}$ caso (...) de um traje que me tivesse sido roubado e que eu reencontro na loja de um adeleiro. Trata-se de uma entidade material, que reside unicamente na substância inerte, o pano, o forro, os aviamentos etc. Um outro traje, por parecido que seja ao primeiro, não será o meu. Mas a identidade linguística não é a do traje, é a do expresso e da rua. Cada vez que emprego a palavra Senhores, eu the renovo a matéria; é um novo ato fônico e um novo ato psicológico. $\mathrm{O}$ vínculo entre os dois empregos da mesma palavra não se baseia nem na identidade material nem na exata semelhança de sentido, mas em elementos que cumprirá investigar (...) (SAUSSURE, 2006: 126 -127) 
Selecionamos as encenações de Medeia como material passível de apreciação comparativa da emissão vocal. Pois, embora a tragédia de Eurípides, a atriz, Juliana Galdino, e o encenador sejam os mesmos, as encenações trazem as escolhas e as invenções que singularizam seus próprios discursos. A problemática das identidades constituídas ou pressupostas é uma temática ampla, de modo que as esboçamos junto às análises seguintes.

Procuramos as recorrências nos modos de entoar. Com isso, a peculiaridade de cada encenação é apresentada por suas semelhanças internas. Cada uma das concepções de Medeia revela uma estruturação particular, relativa aos seus próprios processos de significação. Convém ressaltar que não se trata, simplesmente, de duas execuções da mesma obra dramática. Pois há algo além da extração de dois momentos em temporadas distintas. É sobre essas características distintivas que fazemos incidir nosso olhar. Assim, a descrição não pretende atestar somente que, de fato, um novo ato prevê a "renovação" das palavras.

Trabalhamos, portanto, sobre a hipótese de espécies de partituras subjacentes às entoações, marcantes em cada uma das concepções cênicas. E, por meio disso, procuramos reconhecer as formas escolhidas ou inventadas e seus próprios conteúdos. Desse modo, o confronto entre essas escrituras traz as possibilidades, de um lado, de exposição das diferenças expressivas e, de outro, de aproximação do que se discute como linguagem teatral. Essas estruturações configuram um esboço das especificidades dos projetos estéticos ou das programações que deveriam perpetuar na memória dos atores, construída pelos ensaios e pelas marcas da direção.

Para tanto, assistimos repetidas vezes à gravação em audiovisual dos espetáculos. Ao mesmo tempo, afinamos nossa escuta de acordo com as condições que viabilizam uma descrição. Os procedimentos de retorno e de reconstituição dos sentidos na encenação teatral são operados diante da expectativa de recorrência do ato.

Diante dessas possibilidades de expressão da cena, em Medeia, (2001) e (2003), o modelo tensivo surge como arcabouço teórico para a compreensão do discurso mobilizado pela voz do ator teatral. Num primeiro momento, a descrição segue duas etapas: a primeira analisa a voz em cada encenação e a segunda compara 
os comportamentos dessas emissões, procurando colocar em relevo suas diferenças de sentido. Ao observarmos escolhas expressivas contrastantes, estabelecemos uma interlocução com algumas das noções que comporiam certa "prosodização do conteúdo" (ZILBERBERG, 2006 a: 100). Num segundo momento, nos colocamos diante de uma primeira aproximação dos estilos tensivos, ensejados pela regência da sintaxe intensiva, na projeção dos paradigmas da tonicidade e do andamento.

\section{2 Medeia (M1), primeiro excerto: sobre a tensão e a dúvida.}

$\mathrm{Na}$ primeira encenação, as durações dos silêncios posicionadas entre as tonificações reforçam a assimetria ou a irregularidade dos perfis e da personagem. A progressão do discurso entoado é encontrada na aparente oscilação desordenada. As longas pausas bloqueiam o fluxo da frase, enquanto no momento seguinte a aceleração e tonicidade imprimem o crescendo das intensidades. Quando o preenchimento descontínuo, entre sons e silêncios, torna-se então uma constante, a ruptura e a aceleração são tomadas como estabilização do caráter dessa construção.

Se concebermos a rítmica como aparecimento regular das figuras que a compõem, então não será a contenção de batidas precisas que se tornará o foco de atenção desse excerto. Podemos dizer que o acento tonal impõe-se, portanto, como regente na configuração do perfil e que, com isso, M1 é programada pela tonificação. Além disso, suas modulações configuram uma curva ascendente nos usos das acelerações, acrescentadas às finalizações dos temas acentuais.

Os aumentos da tonicidade e a velocidade, que provocam o acme, o clímax, geram certa dubiedade à personagem dessa encenação de Medeia. O acento tonal, ou a intensidade que é acrescentada à modulação das alturas, pode surgir como demarcação das frases interrogativas. Mas, M1 não gera um quadro de pergunta e resposta, ou não inverte os acentos. Ou melhor, a modulação ascendente não surge seguida duma descendente, de modo que a tensão se complete com o repouso subsequente. M1 se lança ao emaranhado de perguntas sem respostas que soam como uma ambiguidade para a definição de seu estado. 
Nesse primeiro excerto, encontramos a ausência de respostas. Em outras palavras, as expectativas por resolução entram em suspensão. Ocasionalmente, o silêncio pode surgir como repouso, na medida em que tomamos a própria falta de som como uma solução em si mesma. A sonoridade, seja ela perturbada como um ruído ou perfilada como na melodia, é ainda figura do movimento, resultante do gesto necessário para a sua produção e das obstruções que condicionam sua propagação. No caso de M1, a irrupção tônica torna-se suspense e o silêncio decorrente da descendência da tonicidade é tanto chegada quanto retorno.

A ausência da sonoridade, posicionada na coda, não é suficiente para o arremate. A modulação não se encerra na falta de movimento. Pelo contrário, a personagem cala-se por excesso de dinâmica. O silêncio, em sua disposição aspectual completiva, permite intensificar a expectativa de renovação do desenvolvimento. Seu silêncio é tomado como suspensão ou elevação, tendo em vista a não congruência entre seu posicionamento sintagmático e o papel narrativo no encadeamento sonoro. O silêncio ocupa o espaço sintáxico da terminação, ao mesmo tempo em que ele é iminência de um acontecimento, como retomada do programa.

\subsubsection{Segundo excerto: uma hipérbole sonora ou o exagero ambíguo.}

O segundo trecho segue dentro da mesma cena. Assim, a intervenção do coro traz mais uma tensão com a qual M1 retoma sua fala. O início do lamento da suplicante ocorre no alongamento da duração inicial, reforçado pela desaceleração do andamento sobre a rítmica. A dinâmica da tonicidade, ainda crescente, é observada em segmentos mais extensos do que os apresentados na primeira intervenção da personagem. O primeiro excerto apresenta um acento tonal regular, pontuando as finalizações de cada perfil, já o segundo excerto possui o acúmulo de tonicidade como preenchimento que percorre toda a frase, intensificando-se a cada repetição.

O parâmetro acústico da intensidade, ou a tonicidade no modelo tensivo, altera seu regime de presença do primeiro excerto para o segundo, de pontual e intenso para durativo e extenso. Assim, em M1, a tonicidade encontra-se na forma disseminada, na 
procura da máxima expiração e de volume na emissão dos temas acentuais. O volume crescente está associado tanto à abreviação das durações quanto ao consequente crescimento da aceleração. No momento em que há acréscimo de tonicidade e velocidade, a temporalidade é abreviada e a espacialidade sofre com o estreitamento.

As exigências de velocidade e de volume trazem dificuldade para a dicção. M1 pisoteia a língua com a arcada dentária. Em alguma medida, o paroxismo se deixa ver na tentativa de sua retenção. O espasmo da perplexidade pode decorrer tanto da paralisia do espanto, quanto da exaltação e do êxtase. Desse modo se trabalha sobre os silêncios como resultantes da extinção dos sons. Nessa espécie de polifonia surda já anunciada no primeiro excerto, a respiração é arfada, como se a personagem tomasse um trago do ar na aspiração profunda, corrompida pela garganta. Saltando do silêncio ao grito, M1 reinicia seu programa de modulação vocal, chegando vertiginosamente à aniquilação das possibilidades de continuidade da emissão. A voz inicia mansa como o lamento de uma vítima, ganhando em intensidade, ela transforma-se rapidamente na distribuição dos limites de diferentes afetações. Nessa programação de excesso de tonicidade, os gritos de M1 transitam nas fronteiras ásperas (da ira ou da vingança) e agudas (de desespero ou de medo).

Os acúmulos das intensidades surgem como a constante do comportamento da modulação de M1. De maneira repetitiva atualiza-se o excesso, com alterações ou deslocamento tanto na disposição dos acentos pontuais quanto nas qualidades de timbres vocais resultantes. Desse modo, a tonificação promove como procedimento complementar a chegada deslocada dos acentos, esperados, problematizando a certeza de sua estratégia ou deliberação dessa personagem diante da situação. Os tons obstruídos por diferentes articulações poderiam corresponder às oscilações das suas paixões, dificilmente delimitadas a não ser pela ambiguidade já prenunciada como um dos eixos dessa construção.

A voz resulta numa espécie de angústia ou de acossamento, em que a abundância de impulsos é suplantada pelo fracasso ou frustração de seu expurgo. Enquanto vítima dos acontecimentos no encontro com seu destino inexorável, M1 entra em comiseração como suplicante, recaindo em piedade por si mesma. É certo que, nesse momento, os deuses não respondem e ela terá de agir. Nessa defrontação, 
em que a personagem está no embate consigo, o momento catártico já se prenuncia, embora o não compadecimento do herói trágico ganhe contornos dramáticos no sentido moderno.

O quadro abaixo resume essas primeiras análises, de modo que os componentes generalizáveis na passagem do primeiro para o segundo excerto são conformes à mesma célula de base, ou seja, a atualização do excesso perpassa ambos os momentos analisados. Na primeira linha do quadro, observa-se a síntese dos usos de tônus e velocidade; caberia dispor como mais uma unidade a ausência das sonoridades na subsequência do excesso. Na segunda linha, os parâmetros acústicos alteram o aspecto de seu aparecimento de pontual para durativo, na passagem do primeiro excerto para o segundo. Na terceira linha, a tonificação é avaliada segundo seu modo de existência, para que a temporalidade apareça segundo sua base tensiva. Observando os "modos da tonicidade", o estilo tônico desse discurso incide sobre a reprovação do excesso, bem como sobre o estado de alma de M1. (ZILBERBERG, 2006 a: 98)

\begin{tabular}{c|c} 
Entoação & Força e velocidade ascendentes \\
\hline \hline Aspectualidade & Pontual / Durativo \\
\hline Tonificação & Atualização do excesso \\
\hline \hline Temporalidade & Retentiva
\end{tabular}

\subsection{Medeia 2 (M2), primeiro excerto: sobre os regimes de acentuação.}

Extraímos da segunda encenação um comportamento vocal marcado por maior constância das figuras rítmicas no que diz respeito tanto ao seu posicionamento regular dos acentos quanto às suas durações, que em termos tensivos podem ser vistos na 
projeção da tonicidade sobre a temporalidade. Com a regularidade dessa acentuação, o andamento acelerado dessa manifestação é obtido.

Na segunda encenação, o investimento sobre o ritmo e a complexidade de sua estabilidade é evidenciado. Os possíveis recortes das consecuções ganham contornos coesos, na medida em que o aspecto perfectivo (pontual e iterativo) deve ser avaliado para a criação da periodicidade das medidas temporais. Nessa elocução, as durações articulam-se em série, num agrupamento que praticamente ganha métrica de poema. As frases rítmicas são contempladas a partir do momento em que se singularizam em suas relações mútuas.

Seria importante esclarecer que o trabalho com ritmo subentende muitas vezes, primeiramente, diferentes fluxos temporais, e posteriormente, uma reflexão sobre essa rede de acentos que convivem em diferentes modos de existência. Teríamos de discutir questões relativas à linguagem musical e uma passagem da estrutura serial, e o que se estabelece na linearidade, para os valores gerados em concomitância e na superposição. Da mesma maneira, seria necessário supor uma hierarquia manifestada entre as entidades temporais, tais como, por exemplo, compasso e subdivisão, ou ainda, o que caracterizaria uma regência efetiva entre elas. Ao mesmo tempo, a procura por definições desse gênero, em que a consecução das durações cede espaço às simultaneidades, demanda uma discussão mais extensa do que nossa análise permite.

Dando atenção ao que é explicitado na consecução de durações e silêncios, o ritmo é ainda uma forma linear que vem a ser a realização das figuras em relevo no nível discursivo do excerto. Com isso, é possível compreender que a regularidade nos valores das figuras rítmicas é engendrada na aspectualização da acentuação e de suas durações temporais que configuram suas unidades.

\subsubsection{Do ritmo à variação implícita de seus valores}

O reconhecimento do mesmo perfil rítmico repetido por quatro vezes, num único fluxo respiratório, possui o caráter assertivo. Os modos básicos de modulação 
entoativa - pergunta e resposta (ou tensão e repouso) - são apresentados tão somente na estabilidade da sonoridade, antes mesmo de podermos restituir a sua adequação às paixões, ou a caracterização das intenções correspondentes, expressadas verbalmente. Antes disso, essa personagem é construída na ausência de hesitação, no modo incisivo da sua entoação.

Todavia, devemos apontar o problema da descrição dos valores da duração. Primeiramente, nota-se a simples constatação do alongamento final ou da ênfase terminativa, tomando a sequência de quatro breves e uma longa (UUUU-). No interior da frase rítmica, as durações dos acentos variam conforme os agrupamentos possíveis. Assim, ao mesmo tempo em que os constantes alongamentos finais possibilitam a cesura de um perfil, a sequência das breves revelam a variação interna ao valor preciso de subdivisão. Pois, seria igualmente pertinente que a escansão silábica procurasse inscrever, por fim, o velho e bom iambo ( $\mathrm{U}_{-}$), o pé métrico que traduz essa unidade temporal composta de uma breve seguida de longa. Quando dois acentos são consumados, seus valores internos são rearranjados.

Chegamos a duas organizações internas às células, ao incluir a possibilidade de um valor intermediário, para que se possa englobar o alongamento final como parte do perfil. Observamos a distribuição dos valores das subdivisões em duas maneiras:
1) Quatro breves e uma longa (UUUU-);
2) Dois iambos e uma longa $\left[\left(\mathrm{U}_{-}\right)\left(\mathrm{U}_{-}\right)-\right]$.

A constância imprime uma acentuação implícita, como uma espera, diante da variação potencial. Essa dimensão traz a pertinência de um perfil, mais ou menos regular, que comporta suas subdivisões, permitindo um andamento igualmente constante. Quando já estamos na penúltima apresentação desse perfil, há uma alteração observada tanto pela interrupção do fluxo respiratório, quanto pela modificação da distribuição das figuras rítmicas e melódicas. Antes da pausa e da respiração, com a qual se inicia a impressão de outro ritmo, o andamento é alterado. 
A ênfase nas terminações encontrada, no primeiro excerto de M2, coloca o acento, a dinâmica da acentuação ou da tonicidade, na dupla via de acesso aos seus constituintes. Um acento pode ser tonal ou fruto da energia expiratória, ao passo que essas variações vibratórias não são excludentes quando manifestadas. Na medida em que um alongamento tonifica determinada unidade, há possibilidade da promoção do foco sobre o tom. Os acentos são apreendidos em suas durações e, com isso, no aparecimento das alturas propriamente entoativas ou melódicas.

Assim, mesmo que a melodia não proponha nesse instante grande movimento em relação às alturas, a constância da acentuação atualiza a modulação acompanhada por gradativo aumento do volume de expiração. Movimentando-se principalmente por suas figuras rítmicas, as finalizações das frases soam como realização do repouso, conformando a asserção. A resolução, antecedida por seus passos breves e acelerados, é revelada por uma chegada súbita que retomada o programa anterior de regularidade na acentuação. M2 perfaz o ritmo antecipando o seu retorno, recolocando o golpe certeiro de um princípio inesperado de sua emissão.

Nesse sentido, temos a dupla implicação entre os parâmetros de análise. Pois, de um lado, as alturas no perfil melódico não são selecionadas pela acentuação, mantendo-se como um paradigma analisável de modo independente e latente na sua atualização como possível. De outro, a tonicidade coloca em primeiro plano o comportamento acentual como forma extensa e dinâmica, em que os usos do volume ou força expiratória são difundidos globalmente.

\subsubsection{Segundo excerto: prolepse sonora, antecipação e velocidade}

No segundo excerto, a partir da interferência do coro, M2 responde ao coletivo antecipando sua colocação, na retomada de maneira ríspida. É possível afirmar que a emissão aproveita de maneira precisa três regiões da tessitura vocal: uma, grave e áspera, outra, média e branda e a terceira, aguda e sinuosa. Da mesma maneira, alguns procedimentos rítmicos surgem de maneira constante, como já apontamos 
anteriormente. Nesse sentido, o aproveitamento dos timbres coaduna com o ritmo, suplementando a organização das sonoridades.

A regularidade e a constância da acentuação estabelecem uma relação regrada com o andamento. As pequenas pausas de respiração são interrompidas, quando a emissão é antecipada, contribuindo para a aceleração do retorno das frases. Com isso, poderíamos ratificar o caráter assertivo do primeiro excerto e acrescentar a urgência promovida pelo adiantamento na elocução da personagem. Esse deslocamento do acento, ainda que não seja selecionado pela exatidão característica de sua resolução, compõe o estilo da modulação. Esse fato altera a figura retórica da prolepse, de uma simples previsão pontual para uma homogeinização do caráter compreendido a partir da modulação entoativa.

A alternância entre as regiões da tessitura vocal ocorre de maneira precisa. $\mathrm{O}$ período entoado de maneira intensa e grave contrasta com o segmento seguinte. Essa segunda unidade do segmento é caracterizada pelo baixo tônus do fluxo expiratório e pela tessitura aguda, englobante, compreendendo todo o trecho que expõe a lamúria da personagem. Ao transpor a voz de uma região da tessitura vocal para outra, há uma espécie de glissando em semitons. A exposição e a movimentação de M2 pelo palco coincidem com essas alterações das alturas e as resultantes de timbres por elas proporcionados. De grave e gutural a voz passa à sonoridade aguda e clara no lamento, correspondente ao seu deslocamento das intenções. M2 aproxima-se do proscênio, enquanto realiza a passagem de um afeto a outro.

$\mathrm{Na}$ oscilação entre forte e fraco, a alternância na tessitura vocal possibilita a segmentação dos períodos. O grave surge junto à tonicidade, como força, enquanto o agudo posiciona-se no momento átono. Essa utilização da acentuação e dos espaços de ressonância funciona como alteração de expoentes e determinam seus conteúdos afetivos. M2 sai em sua defesa, alternando a demonstração da ira e do lamento abrandado. Explicita seu estado e sua disposição em situação que pertencem também às vicissitudes do universo narrativo dessa personagem.

Procuramos no quadro abaixo a sinopse do que ocorre na entoação de M2, segundo os mesmos critérios utilizados para analisar M1. Assim, de maneira geral, o 
uso da força surge de modo regular, fazendo com que o tônus seja configurado por meio da sua aspectualidade acabada (perfectiva) e, ainda, repetida. Sua construção rítmica aponta para um maior compromisso com os não-acentos do que com os acentos, conforme assinalamos na linha do modo de existência da tonificação. A temporalidade tomada a partir de sua base tensiva indica a distensão, bem como ela pode ser observada por meio do estilo assertivo dessa personagem. Apontamos anteriormente a figura retórica da prolepse ou do adiantamento, convém ressaltar que esse elemento vem à tona em meio a atualização da atonização, na medida em que modo da tonicidade incide sobre a temporalidade e, especificamente, sobre a subvalência da antecipação.

\begin{tabular}{c|c} 
Entoação & Força regular \\
\hline \hline Aspectualidade & Perfectividade e repetição \\
\hline \hline Tonicidade & Atualização da atonização \\
\hline \hline Temporalidade & Distensiva
\end{tabular}

Para que a descrição possa explicitar o funcionamento interno desses discursos e de seus possíveis conteúdos, seguiremos adiante procurando explicitar o modelo tensivo. Passemos à comparação dos discursos entoativos de uma personagem que se deixa ver a duas vozes.

\subsection{Uma personagem a duas vozes}

As diferentes entradas iniciais das personagens encenadas já anunciam as possíveis oposições entre os eixos semânticos de suas construções, como se o tema regente da composição fosse apresentado logo de início. No primeiro gesto vocal, escuta-se a voz de M1, abafada pelos muros. Ela ainda está na coxia, gritando, fora de si e transtornada. Conhecemos os motivos do desespero, desde que nos lembremos do mito. Sua voz não omite o sofrimento, ainda que a segmentação lexical não esteja 
decifrada. "Eis a tempestade chegando", a ama diz; um tambor marca a pulsação veloz, três átonas e uma tônica. M1 aparece então acompanhada por uma longa pausa, ela avança do fundo ao centro do palco e transforma essa aceleração em espera e tensão.

A outra, M2, faz uma pequena aparição, descortinando sua presença e seu desejo mais iminente. Surge, amaldiçoando Jasão e seus filhos, imbuída pela intenção de retaliação. Ao contrário de $\mathrm{M} 1$, que faz de seu primeiro surgimento apenas na distorção dos gritos suplicantes e desesperados, a resolução de M2 também está evidenciada por seu corpo trazido em cena. Na comparação dos modos de emissão, escutamos em M1 a hesitação e a suspensão das resoluções diante do sofrimento, enquanto, em M2, a emissão pode ser apreendida a partir da assertividade. Da mesma maneira que ritmo de M2 é ponderado, sua posição diante das circunstâncias é marcada pela possibilidade de asserção.

Em meio aos nossos apontamentos comparativos, temos duas questões que parecem relevantes. Primeiramente, há a exposição dos traços que configuram os diferentes comportamentos da modulação entoativa. Em seguida, as recorrências, que compõem esses comportamentos, declinam na caracterização das personagens. Pois, de um lado, M1 expõe-se buscando sustentar o fluxo expiratório abundante. De outro, seus excessos incorrem na impossibilidade de manutenção do excesso e, consequentemente, na interrupção da emissão vocal. Com isso, observamos o caráter hesitante e heterônomo dessa construção que traz grade apelo ao ouvinte. A personagem revela-se por meio de sua renovação de impulsos continuamente interrompidos. Esses impulsos de intensidades são tomados ora como golpes sofridos pela personagem diante das circunstâncias. Na construção de $\mathrm{M} 1$, a hesitação e as rupturas perfazem sua entoação, conforme ela é assolada pelas paixões. A voz ecoa uma personagem que se torna uma superfície para os impactos que estão fora de seu próprio controle.

O comportamento da modulação em M1 é indicado por uma série de interrupções, gerando suspensões. Uma delas é a do andamento que, por sua vez, interpela os usos das durações, perfiladas ritmicamente. A flutuação rítmica impõe a aceleração como um procedimento suplementar para regular a resultante das 
interrupções. Assim, a reprimenda do atraso ou a espera que não se pode mais conter irrompem numa velocidade que suspende as possibilidades tanto de repouso quanto de determinação esperada de um acento.

Essa configuração opõe-se em alguma medida àquela apresentada por M2. A segunda encenação manifesta uma personagem à procura de coesão rítmica. A atuação mais contida e a regularidade na disposição dos acentos traçam perfis rítmicos semelhantes. A contenção desta Medeia permite maior atenção às mudanças de timbre, o que colore sua fala. Com isso, a variedade de espaços de ressonância gera uma exposição das paixões de maneira gradativa. Desse modo, a personagem revela-se num caráter autônomo e mais controlado.

M2 surge mediante suas repetições, sobretudo, de ritmo e de andamento constante. A personagem não perde tempo com interrupções e suspensões, mas ganha com antecipações na colocação de uma nova frase. As alterações de andamento nos atrasos de M1, ou nos adiantamentos de M2, são complementares aos outros procedimentos contemplados. É possível afirmar que M2 é mais veloz do que M1, apesar dos rompantes acelerados de M1, na medida em que a continuidade da acentuação economiza a temporalidade cronológica e organiza um acento regular e esperado.

\subsubsection{Estilos tensivos}

A descrição do comportamento das entoações convoca as categorias tensivas como, por exemplo, no uso hiperbólico da tonificação, tal como surge em M1 de maneira retentiva. Convém, portanto, explicitar a mobilização dessas categorias que, até certo ponto, podem ser percebidas a partir de sua matriz prosódica. Desse modo, procuramos uma síntese das reflexões concretizadas até então, bem como a aproximação entre essas análises e a teoria tensiva. Para tanto, nossa principal referência é a obra de Claude Zilberberg e, em especial, a sintaxe discursiva intensiva dos Éléments de Grammaire Tensive (ZILBERBERG, 2006 a: 84 -100). 
O acento (ou a intensidade) é configurado como elemento chave para acessar o modelo, contudo, ele logo se desdobra. De um lado, na subdimensão do eixo da intensidade, a chamada tonicidade é articulada em forte e fraco, manifestada no ritmo. De outro, apreendida em sua forma disseminada, a acentuação é flexionada em ascendência e descendência. Por sua vez, essas direções são imprescindíveis para esquematizar a dinâmica e a inflexão das alturas, possibilitando a geração dos estilos tensivos dos discursos em questão. Há ainda outra subdimensão da intensidade: o andamento regrado por acelerações e desacelerações. Primeiramente, trataremos da tonicidade e do modo como a análise interpela seu lugar na teoria tensiva. Em seguida, procuraremos dar atenção ao andamento, na medida em que certos aspectos da velocidade devem ser relacionados com a configuração rítmica.

É necessário ressaltar que as sintaxes da tonicidade e do andamento presentes em Zilberberg são pensadas como questões do conteúdo, embora pertinentes na descrição de ambos os planos da linguagem. De fato, analisamos o plano da expressão das sonoridades, tendo em vista que esse plano colabora com os sentidos de um dado projeto estético. Isso quer dizer que a expressão não está encerrada em si mesma. De alguma maneira, os usos dos procedimentos vocais anunciam os conteúdos e reverberam a significação desses projetos. Assim, a voz enquanto objeto estético posiciona o sujeito enunciativo das encenações teatrais e, consequentemente, seleciona as qualificações modais e passionais dessas encenações.

$\mathrm{Na}$ teoria da entoação, a ascendência na inflexão entoativa está associada ora à pergunta ora à exclamação, enquanto a descendência à conclusão. Esses conteúdos não dizem respeito somente ao nível frasal que explicita essas unidades, mas também constituem o nível discursivo das personagens encenadas. Assim, essa articulação, bem como a relação acontecimento (tensão) e estado (resolução) (ZILBERBERG, 2006 a: 17), tornam-se decisivas para observar que M1 é mais hesitante, enquanto M2 é mais resolutiva. Além dessas noções elementares, outros apontamentos tornam-se importantes, pois a sintaxe intensiva promove o entendimento das construções das personagens em questão.

Outro princípio que participa das análises é o da "parada da continuação" ou o princípio da contenção. Esse componente funcional é mais facilmente apreendido 
como uma irrupção pontual e, dito de outra maneira, como o impacto de um acontecimento. Mas, além dessa constituição mais imediata, a contenção pode também ser aspectualizada, ganhando relevos temporais e espaciais específicos em suas manifestações. Ambas as construções das entoações das personagens analisadas estão articuladas com essa categoria, mas cada uma a sua maneira, como contemplamos ao retomar nossa descrição logo abaixo.

A partir disso, pontuamos o aparecimento dessas noções (tonicidade e contenção) na confluência das análises até esse momento. De maneira predominante, em M1, a projeção da tonicidade sobre a temporalidade produz os efeitos de dinâmica na entoação, resultantes do alongamento do fluxo expiratório. A primeira encenação transcorre na promessa da descendência, a partir da direção ascendente prestes a se extinguir, ou seja, nas sucessivas elevações esperamos um repouso que não se completa. Seu regime é regrado pelo excesso de tonicidade e aceleração, mobilizando a interrupção da emissão como uma resultante de um processo excessivo que provoca a sua própria descontinuidade. Ocorre uma espécie de acontecimento durativo, em que seu pathos, caracterizado pela hesitação, é marcado por tentativas de manutenção do transitório. O caráter de M1 é concebido a partir do solapamento das medidas resolutivas, na perda da razão. Com isso, o cumprimento da ação surge como consequência dessa desmedida, em que possivelmente a modalização deôntica sobrepõe-se à sua recusa do querer.

Dissemos que M1 é marcada pela retenção que, neste caso, funcionaria como um elemento para a configuração de seu estilo suspensivo. Nesse sentido, a emissão vocal é tanto contida quanto retida. Em outras palavras, no prolongamento da interrupção da emissão, há também um aumento da tensão, tomados a partir dos acréscimos de tonicidade e de aceleração. Sua hesitação pode também ser percebida nesse instante, pois a remissão seria o momento para tomada de direção oposta. No lugar de acréscimos de intensidades, deveríamos encontrar a atenuação delas. O excesso de M1 torna presente uma espera aflita, pois repetidamente ela interrompe o curso, para retomar a produção de mais intensidades. O estilo suspensivo, que caracteriza M1, é promovido pela atualização constante de uma ruptura. A "parada da continuação" 
pode ser tomada como uma constante de atenuação e, também, como algo que ocorre também pela repetição.

Retomemos também o dispositivo de M2. Na segunda encenação, em M2, encontramos os princípios de resolução e deliberação para um acontecimento futuro, resultante da preeminência da modalização volitiva. No plano da expressão, seu programa afirmativo procede com o aproveitamento da tonicidade em sua prossecução. Para tanto, a tonicidade estaria articulada predominantemente com a temporalidade rítmica. O ritmo se configura pela aspectualização da temporalidade (duração) tanto pelo aspecto perfectivo, quanto pela repetição que promovem semelhanças entre os perfis rítmicos entoados.

Na esquematização de $\mathrm{M} 2$, essa construção traz também uma relação com a contenção, para que seu ritmo mais preciso possa ser gerado. Afinal, se não houvesse cesura, não haveria também subdivisão rítmica. Desse modo, o aparecimento constante de um perfil manifesta-se enquanto sua descontinuidade está subentendida, como uma propriedade que compõe as figuras rítmicas. Para tanto, o estilo de M2 é determinado pelo aspecto perfectivo ou terminativo.

Sendo assim, encontramos na fala de M2 certo repouso, formado entre a contenção e a distensão da modulação entoativa. Observamos que M2 não coloca em dúvida suas competências para a ação e nem imputa o fato de levar adiante sua ira a uma obrigação externa. Com isso, aventamos certos conteúdos derivados dos componentes expressivos contemplados na descrição. A partir da configuração tensiva de sua expressão, surgem possibilidades das modalidades do fazer. Assim, M2 calcula a execução do ardil e o seu desejo de vingança é demonstrado. Podemos compreender M2 a partir da resolução e previsão de chegada da eclosão catastrófica. 


\begin{tabular}{c|c|c|c|c|c} 
Tensão & $\begin{array}{c}\text { Contenção } \\
\text { (parada da } \\
\text { continuação) }\end{array}$ & $\begin{array}{c}\text { Retenção } \\
\text { (continuação da }\end{array}$ & $\begin{array}{c}\text { Distensão } \\
\text { (parada) }\end{array}$ & $\begin{array}{c}\text { Relaxamento } \\
\text { (continuação) }\end{array}$ \\
\hline
\end{tabular}

\begin{tabular}{c|c|c}
\hline \hline $\begin{array}{c}\text { Fazer } \\
\text { missivo }\end{array}$ & $\begin{array}{c}\text { Fazer remissivo } \\
\text { (descontinuidade) }\end{array}$ & $\begin{array}{c}\text { Fazer emissivo } \\
\text { (continuidade) }\end{array}$ \\
\hline \hline Aspecto & Durativo & Perfectivo
\end{tabular}

Além desses elementos que procuramos tratar até o momento, consideramos importante a reflexão sobre o andamento, pois ambas as personagens são aceleradas de maneira geral. A fala no teatro tem um andamento diferente daquele do cotidiano. Com isso, devemos supor de imediato que as velocidades geradas em cada uma dessas emissões vocais possuem suas especificidades. É sobre essa questão que refletimos neste próximo momento.

\subsubsection{Gerenciamento da concomitância entre andamento e ritmo}

Na fala, a organização simultânea do ritmo e do andamento é algo totalmente intuitivo, enquanto no pensamento musical ela ocorre na confluência dos fluxos temporais, em tal medida que até mesmo o ritmo poderia ter seus formantes separados como os tons na harmonia. Para compreender essa multiplicidade, ou essa polirritmia, é necessário gerir não somente a linearidade na disposição dos acentos como também a concomitância dos aproveitamentos das extensões temporais e de durações latentes. Procuramos tratar dessa questão como uma propriedade da relação entre ritmo e andamento, tendo compreendido que o ritmo é a injunção da tonicidade sobre a temporalidade que alonga ou abrevia o acento forte ou fraco.

Como já dissemos, em M1, a entoação caracteriza-se por rupturas e retomadas, promovendo o recrudescimento de um estado suspensivo. Essa construção, ao mesmo tempo em que é acompanhada pelo atraso, é constantemente restabelecida pelo acréscimo de tônus e velocidade. Em outras palavras, mesmo que acometida pelo excesso no investimento sobre o eixo da intensidade, a personagem ainda procura 
reparar uma falta. A hesitação é gerada então pelo embate entre dois programas. De um lado, o excesso exige uma direção descendente, do mais ao menos intenso. De outro, a falta pede uma direção ascendente, do menos ao mais. Assim, tonificação e aceleração caminham indissociáveis.

Devemos diante disso nos concentrar sobre o ponto em que os rompantes de M1 selecionam certo atraso na construção da personagem. Isso também é notado a partir do momento em que a construção da entoação apresenta consequências na passagem cronológica do espetáculo, sendo a encenação de M1 mais demorada do que em M2. O primeiro espetáculo dura uma hora e seis minutos, já o segundo passa em cinquenta e dois minutos.

É certo que as horas do relógio podem ser esquecidas dentro da sala de espetáculo ou, simplesmente, na proposta de um mundo ficcional. Nesse ambiente, não nos preocupamos com a unidade temporal à moda antiga, pois um espetáculo não é construído perante uma restrição primordial promovida pelo tempo cronológico. Mas é interessante de fato notar, com isso, a divergência entre preenchimentos de diferentes proporções durativas.

Durante a encenação que se alonga, a entoação apresenta-se de maneira contrária. Ela pode ser acelerada, como ocorre em M1, pois, a profusão dos gestos vocais projetados abrevia as durações no interior da modulação entoativa. Contudo, vemos que as inscrições descontínuas dos componentes expressivos promovem a aceleração da entoação de M1, mas não a velocidade da encenação como um todo. Em M1, há uma incompatibilidade entre essas impressões e a espera de um andamento constante. Nessa simples divergência, a encenação inscreve dois coeficientes de andamento, sendo um dos coeficientes a resultante de uma velocidade uniforme, compreendida no andamento global da encenação, enquanto a outra é variada nas acelerações pontuais do ritmo perfilado por M1.

$\mathrm{Na}$ interseção entre as acelerações pontuais da entoação e a velocidade global da encenação, M1 atrasa a chegada ao fim do espetáculo, pois sua entoação propõe a aceleração pontual e o excesso de tonificação. Desse modo, destacamos duas questões para essa reflexão. Em primeiro lugar, o gerenciamento da concomitância entre 
andamento e ritmo. Em segundo lugar, o posicionamento das personagens em relação ao cumprimento da ação, como uma chegada ao repouso.

De fato, a reflexão sobre a relação entre ritmo e andamento ocorre de maneira intrincada, pois a espera dos ataques acentuais implica um intervalo estranho à efemeridade do acento manifestado. Por sua vez, o andamento surge na distância entre os acentos esperados, como se a velocidade estivesse na divisão do ritmo. Mas, na espera pelos acentos, uma acentuação implícita desempenha sua função junto ao aparecimento das figuras. À proporção que o andamento subjaz ao ritmo, ele pode também regularizar a conformação da subdivisão rítmica. Desse modo, a manifestação do andamento depende do ritmo, ao mesmo tempo em que o andamento determina o perfil rítmico.

Esses aspectos do andamento são observados na comparação das entoações de M1 e M2. A primeira é acelerada ao variar as velocidades como uma tendência de acompanhamento para a sua tonificação. Em decorrência de um aproveitamento específico da tonicidade, os movimentos fortes da entoação de M1 resultam também na sua aceleração, ao mesmo tempo em que essa relação entre tonificação exacerbada e rapidez pontual proporciona uma demora na velocidade global, quando comparada com M2. Podemos examinar M1 como regida pela variável da aceleração, na medida em que isso integra uma variação das velocidades.

Assim, M1 está atrasada enquanto o espetáculo é alongando, como se ela estivesse ainda distante para finalizar seu percurso de deslocamento no cumprimento da ação. Ela pode ser veloz em si, mas seu movimento na duração do espetáculo é lento. Assim, embora M1 seja acelerada pontualmente, a encenação apresenta uma velocidade diversa dessa aceleração, mobilizando o atraso no acabamento da encenação.

De outra maneira, M2 está mais próxima da finalização da encenação e do cumprimento da ação, porque ela é globalmente veloz. Enquanto M1 atualiza seu programa de acelerações pontuais, M2 já cumpre com programa de velocidade global. Ao seu modo, M2 atualiza um ritmo regular que, por sua vez, subordina-se ao 
andamento mais uniforme, promovendo uma velocidade global para sua atuação. Assim, a qualidade constante do andamento determina o ritmo de M2.

A regularidade de $\mathrm{M} 2$ diz respeito tanto à disposição dos acentos, quanto à uniformidade de uma velocidade constante. Tendo em vista que a regularidade de M2 a posiciona como uma personagem mais veloz, as proporções de seu ritmo constante e suas consequentes qualidades de movimento regular economizam seu percurso de deslocamento na duração da encenação. Em M2, seu ritmo converge para uma acentuação contínua, promovendo uma velocidade mais uniforme compreendida doravante no aproveitamento de sua ação em relação à sua chegada.

A narratividade constituinte dos discursos da entoação, bem como dos objetos sonoros, pode ser encontrada na subjacência dessa reflexão. Afinal, o ritmo sugere espera e chegada que, por sua vez, são articuladas entre tensões e repousos nas formas do acontecimento. Essa relação entre ritmo e andamento implica em semantismos para os desenlaces daquele enredo que pode ser tomado por meio dos investimentos figurativos e passionais - pela traição e pelo abandono, Medeia acometida pela ira imola a realeza de Corinto e os próprios filhos.

Mas, nesse momento da análise, a narratividade está comprometida com as impressões temporais vividas durante o espetáculo, ou seja, com a articulação entre a espera de um final e o envolvimento com as intensidades da entoação (aceleração e tonificação). Certamente, na sintaxe intensiva, a narratividade sobre a qual refletimos posiciona Medeia no cumprimento do ato, na passagem do estado para o acontecimento. Assim, em M1, diante de tantas quebras das sonoridades e, consequentemente, nos seus arrebatamentos passionais, a ação propriamente dita parece secundária. A personagem é solapada pelas paixões, dando intensidade a cada momento, como se sofresse sem interrupção uma perda.

Sendo assim, em relação ao cumprimento ou à frustração do acento esperado, em M1, localizamos uma aceleração disfórica, decorrente das intensidades que resultam em suspensões silenciosas. Por sua vez, em M2, ocorre o contrário, pois o regime de semelhança entre os perfis rítmicos promove uma aceleração euforizante. Assim, com a acentuação regular e na procura pela conclusão de seu percurso, há a 
chegada do esperado. A aceleração disfórica estaria associada à preponderância da tonicidade como dinâmica extensa, enquanto, na eufórica, à constância do ritmo engendrado na velocidade global.

Em suma, buscamos explicitar uma possível relação entre o andamento e o ritmo para observar diferentes coeficientes de velocidade na espera do cumprimento da ação. Desse modo, extraímos das modulações vocais diferentes posicionamentos das personagens encenadas em relação à finalização e, por assim dizer, do repouso de suas tensões. A dependência entre o ritmo e o andamento está presente em Zilberberg (1996: a18), bem como seus semantismos (2001: 22). Conforme segue no quadro abaixo, procuramos as sínteses nos usos das velocidades, apontando uma possível leitura para essa questão em cada espetáculo analisado.

\begin{tabular}{cccc} 
Andamento & \multicolumn{1}{c}{ Semantismo } \\
\hline \hline Aceleração disfórica & Medeia 1 & \\
\hline \hline & & \multirow{2}{*}{ Não cumprimento do esperado } \\
\hline \hline Aceleração eufórica & Medeia 2 & \\
\hline \hline & & \multirow{2}{*}{ Cumprimento do esperado }
\end{tabular}

Em seu discurso, M1 dispõe um andamento acompanhado pela tonificação excessiva, gerando acelerações enquanto forma de preenchimento pontual. Essa espécie de aceleração diverge em relação à passagem da temporalidade regular ou cronológica, de tal maneira que o espetáculo demora a passar. Sua rítmica, composta de rompantes dinâmicos, pausas e ainda de acelerações pontuais é percebida ora como atraso, ora como alongamento da duração da encenação. No discurso de M2, a regularidade do perfil rítmico converge para a presença marcada do andamento em sua forma global. Assim, na relação entre ritmo e andamento, os diferentes coeficientes de velocidade alongam ou abreviam a duração do espetáculo, tendo em vista que esperamos sua finalização. 
Medeia 1

Medeia 2

\begin{tabular}{l|c|c}
\hline \hline Tonicidade & Atualização da tonificação & Atualização da atonização \\
\hline \hline Andamento & Aceleração pontual & Velocidade global \\
\hline \hline
\end{tabular}

Temporalidade

Atrasada

Adiantada 


\section{Relações entre ação e motivação}

Nas análises seguintes, examinamos a relação entre as situações dramáticas e os discursos da entoação. Para tanto, dois episódios da tragédia Medeia são examinados na comparação entre as encenações de Antunes Filho. No primeiro episódio selecionado, Medeia encontrando Jasão, o amante que a traiu, expõe as injustiças sofridas. No segundo, ela está novamente diante dele, mas dissimula suas intenções para executar sua vingança.

As análises seguintes são compreendidas como subsequentes às anteriores. Podemos agora nos dedicar à mobilização da ação propriamente dita, tendo em vista que passamos pelas construções das personagens encenadas. Procuramos anteriormente traçar como a voz da atriz evidencia as diferentes construções de Medeia, o que já posiciona as personagens em relação à narratividade das tensões e dos repousos. Consideramos que M1 atualiza o excesso e uma interrupção subsequente à excessiva tonificação da entoação, de modo que esse mecanismo reverbera no encadeamento fabular dos episódios esperados da peça. Já na segunda encenação, a entoação pode ser percebida na busca pela constância do ritmo. Assim, pensamos que o discurso entoado altera a constituição da personagem e, por isso, a criação da situação.

$\mathrm{Na}$ análise anterior, foi possível observar os procedimentos vocais recorrentes que se destacam nas construções das personagens encenadas. As intenções e as atitudes, simuladas pela voz da atriz, em alguma medida homogeneízam o que identificamos como essas construções. Esse posicionamento discursivo convoca efeitos de sentido, diferenciando as situações da progressão dramática. Se na primeira encenação Medeia é determinada por uma série de rupturas e retomadas e, na segunda, ela procura por constâncias e regularidades, as encenações têm seus sentidos relacionados com seus modos de emissão. Convém, portanto, nos ater a relação entre situação (ação) e motivação (qualidades modais e passionais). 
Inicialmente, supomos que as personagens fossem posicionadas nas encenações a partir das situações sugeridas pela dramaturgia. A personagem seria construída no confronto com a trama encenada e estaria sujeita às flutuações da curva dramática, o que modularia sua voz. Contudo, tivemos de recusar parcialmente essa hipótese condutora da análise, na medida em que se tornaram nítidas as possibilidades de nuançar a própria situação e não mais as modulações vocais.

De outro modo, as modulações entoativas nas encenações de Medeia são configuradas junto aos traços pertinentes no comportamento do caráter das personagens. Assim, esses espetáculos colocam em questão a objetivação das suas intenções (disposições necessárias, ou transitórias e contingentes para a ação), suas relações com a situação e, finalmente, a eclosão do ato funesto. Podemos dizer que, contemplando comparativamente os usos da voz em cada encenação, percebemos as possibilidades de composição de diferentes intenções para ação e, sobretudo, como as construções do caráter de Medeia já prenunciam a chegada ao ato.

Convém, antes de tudo, esclarecer algumas noções encontradas na confluência terminológica da semiótica e dos estudos teatrais, sem a pretensão de exaurir os problemas em questão. Pelo contrário, vemos que a discussão entre os conceitos da teoria semiótica e os de uma prática artística seria outro trabalho a ser realizado. Mas, podemos destacar de antemão o escopo que procuramos abranger na análise. A partir da análise da modulação entoativas é possível esboçar a disposição das intenções em cena e a configuração da situação, compreendidas como modalizações do fazer. Com isso, os programas modais são examinados de um ponto de vista semiótico, enquanto a noção de situação surge como uma preocupação característica da manifestação teatral.

Na obra de Étienne Souriau, As Duzentas Mil Situações Dramáticas, o enfoque sobre a dinâmica e o andamento da ação, em "momentos exclusivos, intensos e patéticos" (SOURIAU, 1993: 28), é colocado como indispensável. Para além da necessidade de restrição ao elemento fundamental do teatro, a situação permite a articulação de diferentes categorias semióticas. Pois, dispostas como passagens e convergências, encontramos tanto o caráter da personagem teatral, ou sua disposição passional, quanto um modo de agir que culminam no cumprimento da ação. Essas microestruturas permitem abordar a personagem e sua atuação de modo que sejam 
apresentadas como funções, ou papéis, que interagem com os instantes compreendidos pela ação global da peça. Assim, Souriau comenta esses diferentes interesses:

Às vezes o que nos interessará será um caráter - $\mathrm{O}$ avarento, Le glorieux, L'indiscret, L'enjôleuse, La menteuse (Doris); ou melhor uma individualidade, seja Fedra ou Hamlet; Otelo (que não é apenas um Ciumento), ou Orestes (que não apenas o Saturnino) (...). E às vezes será somente uma situação: Ximena obrigada a pedir a morte daquele a quem ama; Didier recusando-se a ser salvo pela intercessão daquele a quem ama; ou Fabienne (em Thermidor) recusando-se a se declarar grávida para ganhar o prazo de dois dias que salvaria sua cabeça; ou Labussière (na mesma peça) obrigado a escolher entre diversos processos de desconhecidas aquela que mandará para a morte no lugar de Fabienne. (SOURIAU, 1993: 26)

Sendo assim, ação e situação podem ser apreendidas a partir do que compreendemos como categorias narrativas, ao mesmo tempo em que essas podem se articular com as modalidades do fazer. Os exemplos acima ilustram as implicações entre o fato de estar (em recusa ou com obrigação) e a transitividade do fazer em que o sujeito é ativo (pedir, declarar, escolher) ou passivo (ser salvo). Antes de alcançar o retrato do ser humano, as circunstâncias, as deliberações ou as preferências caracterizam as personagens, o que permite estabelecer uma espécie de causalidade para a progressão dos fatos. No âmbito dramático, a ação interpela o caráter ou a decisão. As modalidades de recusa, do não-querer e do dever representam as motivações endógenas e exógenas privilegiadas por Souriau nesse excerto, para que assim a personagem seja posicionada em situação.

De fato, para a definição de seu modelo actancial, Algirdas Julien Greimas, em Semântica Estrutural (1973), passa por definições paralelas dos actantes extraídas de gêneros literários diferentes. As primeiras definições são de Louis Tesnière, em que os actantes linguísticos da sintaxe frástica são posicionados como se estivessem em uma "cena". As segundas são do inventário de funções subjacentes às personagens do conto maravilhoso russo. A elaboração de Vladimir Propp possibilita uma esfera analítica, em que a variedade de investimentos temáticos e figurativos nas personagens possa fazer revelar uma camada mais profunda relativa às suas funções dentro do percurso 
narrativo. Num terceiro momento, Greimas comenta a insuficiência da obra de Souriau, apresentando-a como uma dificuldade comum à investigação de nível formal observada ora como excessivamente limitativa, ora como insuficientemente formal. (GREIMAS, 1973: 230)

Desde então, o modelo actancial surge como um esquema de previsão ou, simplesmente, uma tipologia que considera a transformação do sujeito de estado em um sujeito do fazer. As narrativas mínimas são observadas em dois tipos de enunciado, sendo esses os que colocam o sujeito em conjunção ou, por oposição, em disjunção com os valores de sua busca. Nesse trajeto de transformação do estado disjuntivo para o conjuntivo, o encadeamento lógico das etapas é explicitado na seguinte sucessão: "a manipulação, a competência, a performance e a sanção". (FIORIN, 2008: 29)

Como já apontamos anteriormente em nosso segundo capítulo introdutório ao método, o momento atual da semiótica está voltado para uma promoção da narratividade. Desse modo, segundo Denis Bertrand, a narratividade pode ser vista como dinamismo integrador entre as formas da expressão e as do conteúdo. Essa perspectiva surge na constatação da narrativa como uma das mais amplas classes do discurso. (BERTRAND, 2003: 267 - 268)

Por sua vez, a teoria das modalidades integra-se às etapas de manipulação e, consequentemente, de aquisição de competência do sujeito, na medida em que as modalidades do fazer são projetadas na dimensão pragmática do discurso e, propriamente, quando o discurso torna-se a ação em foco. Assim, na esfera da manipulação e das qualificações modais, encontramos a dimensão patêmica. Em Tensão e Significação, são observadas as diferentes contribuições teóricas, apontando um estudo da modalidade voltado não somente para sua compreensão enunciva, mas também enunciativa, visando desse modo o posicionamento do sujeito em relação ao seu próprio discurso. (FONTANILLE e ZILBERBERG, 2001: 227)

Dito isso, na análise seguinte, procuramos localizar a articulação entre a esfera da manipulação e da ação (ou perfomance), tendo em vista as qualificações modais e passionais nas maneiras em que as personagens encenadas são colocadas em situação 
dramática. De maneira premente, esse capítulo é dedicado ao percurso narrativo e passional das personagens encenadas, avaliando Medeia em relação ao seu ato funesto, a ação propriamente dita, e à sua paixão motora, a motivação para execução dessa ação. Nesse momento, tentamos explicitar os sentidos em cada encenação por meio da composição vocal das personagens. Para tanto, lançamos mão das categorias narrativas e, em especial, daquelas da esfera da manipulação, fazendo surgir qualificações modais da ação e aspectualidades da paixão. Além da avaliação da protagonista, esboçamos também alguns traços nas construções de Jasão, procedendo à análise da dissimulação de Medeia que interpela o crer e o saber de seu antagonista.

\subsection{No embate, invectiva e arrependimento}

No decorrer da tragédia de Eurípides, são três as cenas de confronto com Jasão. Na primeira, Medéia expõe todas as motivações para a sua ira, resgatando em breve narrativa as desventuras pelas quais o casal passara. Na segunda, a personagem dissimula o ardil para a execução da vingança, convencendo Jasão de seu pedido de perdão. Na terceira, o desfecho da ação: ela parte com os filhos mortos no carro do Sol, enquanto Jasão clama pelo direito de enterrar os corpos. As etapas da ação são divididas de modo que culminem na expressão da ira. Os ápices de tonicidade, o inicial e o final, são intercalados pelo falseamento da paixão, como um abrandamento necessário, para que se efetive o engodo.

A primeira cena, portanto, é a cena de embate propriamente dito, em que a personagem resgata o passado, expondo assim as injustiças sofridas como elementos nucleares de sua manipulação. Jasão não diz muito, somente apresenta a condenação de Medeia ao exílio, devido a "suas palavras e atitudes impensadas". Segue abaixo o texto.

Monstro, monstro! Essa imagem que tenho vendo-te tagarelar tão tranquilamente na minha frente. Não é a estatura moral, nem autoconfiante que te coloques nesse pedestal onde imaginas que estás. Ao contrário é generosidade arrogante e o mais infame defeito humano: a insidiosa hipocrisia. Ah, como isso me ofende. Isso me agride, mas também não somente a mim, mas também a todos os homens e também a todos os deuses que não deixam de testemunhar as tuas ações. 
Monstro! Contudo não foi inútil a sua vinda. Poderás ouvir a viva voz com os teus dois ouvidos, todas as ingratidões com que ora me recompensas, por tudo aquilo que fiz. Te salvei, como sabem todos os gregos que estavam contigo na nave Argos. Quando matei o terrível dragão que guardava o teu cobiçado, conquistado apesar de tantos obstáculos, velocino de ouro! E depois, eu mesma, traindo meu pai e minha família, para te seguir, sacrifiquei o meu irmão, Absirto, pois não podia deixar de preservar a vida do meu esposo. E, em Ouco, antes com mais pressa do que com prudência, livrei-te de todas as ameaças do rei Pélias, persuadindo as filhas a matarem cruelmente o próprio pai. Que outros tantos fatos preciso acrescentar para provar a enormidade da tua ingratidão? Se não tivesses gerado filhos em mim, poderia até ter uma desculpa esfarrapada para ir correndo ao novo leito. Seria um ótimo pretexto para ir mantendo sua nobre linhagem. És monstro! Um fingido. Tuas palavras, teus juramentos nada valem. Crês que os deuses já não valem, ou que os céus decretaram novas leis. Ah! A mão direita que apertastes entre as duas mãos tantas e tantas vezes. Ah em joelhos, joelhos que foram tocados por pérfido suplicante. Quantas vezes não fui arrastada por melífluas e malvadas fantasias? Pobre de mim! Mas e agora o que faço? Para onde devo ir? Supondo que ainda seja por um só momento, realmente o meu amigo, o que me aconselharia? Para onde devo ir? Quem me acolheria? Aqueles que não tive necessidade de prejudicar ou injuriar, tornei meus inimigos por tua causa. Enfim, estou perdida, aqui, acolá, no mundo, sem amigos e sozinha. Vivas, portanto, oh valoroso noivo que garbosamente abandona pelas estradas como mendigos a mulher e os filhos.

Em M1, a temporalidade retentiva caracteriza essa construção da modulação entoativa, enfatizando determinadas qualificações modais em relação à situação, configurando Medeia como sujeito passional. A maneira pela qual M1 expõe sua fala parece não procurar uma redenção para sacrifícios passados, mas somente demonstrar dos gatilhos motivadores que legitimam sua ira.

M1 surge marcada pela intensidade máxima do grito, ela diz "monstro, monstro"; há ainda a ocorrência de duas acelerações no segmento final de cada período, sendo que a segunda surge enriquecida por mais tônus. Logo a velocidade e o uso do volume da expiração transformam-se em outro grito para que em seguida a voz se abrande. $\mathrm{O}$ andamento desacelera somente como um abrandamento para mais um ataque. A máxima tonicidade é seguida pelos silêncios das interrupções, decorrente da impossibilidade de manutenção desse excesso. Seguindo sua procura de maior 
intensidade, o retorno da aceleração rompendo, mais uma vez, com possibilidade de gradação na modulação.

Em meio a esses intermitentes rompantes, uma pequena narrativa lembra os fatos que comprovam a fidelidade de Medeia oposta à ingratidão presente de Jasão. Nesse trecho, culminam os efeitos produzidos pela série de abreviações, as durações diminuem em função da grande velocidade. Contudo, assemelhando-se ao procedimento anterior, M1 irá frustrar o apogeu com alteração do modo de emissão. A aceleração parece, ao mesmo tempo, ilustrar aquilo que o enunciado traz como informação sobre seu caráter no passado, pois ela diz: "antes com mais pressa do que prudência”. Em seguida dirá, amenizando o andamento e a tonicidade, alterando o timbre, alcançando laivos de arrependimento e lamento: "livrei-te de todas as ameaças do rei Pélias, persuadindo as filhas a matarem cruelmente o próprio pai”.

$\mathrm{Na}$ relação entre a construção dessa personagem e a situação, notamos, sobretudo, a agressividade de sua invectiva. $\mathrm{O}$ embate expõe a personagem de maneira semelhante a dos tribunais: diante do julgamento presente há sempre a implicação da volta ao acontecimento passado. Em M1, sobressairá uma espécie de defesa voltada para a demonstração de seu estado passional. As alternâncias entre aceleração e desaceleração, entre forte emissão e embotamento da voz, revelam a impossibilidade de seu equilíbrio. M1 passeia de um extremo ao outro, desconstruindo cada estabilização alcançada. Assim, M1, por manter a lembrança da injustiça e da fratura humilhante, na recorrência ao princípio gerador de seu estado, apresenta a chegada ao final catastrófico no modo em que ele é alcançado pelo excesso. Essa Medeia, permanentemente irascível, concentra em sua paixão a plenitude e assombramento do rompimento.

A partir da expressão de M1, a paixão é tomada como objeto autônomo e fora do controle do sujeito, de modo que o percurso narrativo da ira pode ser identificado na etapa inicial, quando há a ruptura de uma espera anterior que institui a personagem em curso. Essa etapa inicial caracterizada pela interrupção determina o caráter de M1 em seus excessos e rompantes. A repetição da interrupção, configurando o comportamento da modulação, sobrepuja a construção das circunstâncias da encenação. 
Os gritos, com os quais M1 começa sua "tempestade de palavras", tornam-se contidos e agravados em M2. Descrevendo a segunda personagem, é possível observar que a maneira comedida da sua exposição promove maior eficácia à dimensão das justificativas, suplantando a necessidade de demonstração da sujeição encontrada na primeira encenação da personagem. Em M2, a regularidade com a qual as ênfases surgem permite tanto a maior inteligibilidade do conteúdo verbal, como também a exposição de uma argumentação que promove o encontro dessa personagem com a ação que se seguirá, a imolação da sua própria criação.

Alguns elementos característicos da emissão de M2 segmentam o texto e, desse modo, uma progressão é realizada conforme as utilizações da voz. Esse excerto, em M2, pode ser dividido em cinco partes, revelando o andamento descendente nos três primeiros trechos, terminado por uma aceleração final e uma elevação nas indagações colocadas pela personagem. A partir disso, foi observada a modificação da tonicidade (do forte ao fraco) e da utilização das regiões de emissão (do grave ao agudo) nesses mesmos segmentos.

M2 inicia sua fala com o abrandamento do ataque inicial, trazendo em consequência a alta velocidade e acentos pontuais e regulares, que recaem sobre as palavras ofensivas contra Jasão, "monstro". No segundo momento, M2 recontando os fatos do passado, o andamento veloz surge com menor recorrência e já os acentos tonificam os conteúdos da narrativa que enfatizam a separação de sua família. Depois disso, a voz se torna mais e mais patética, enfraquecida e aguda como um choro. Ao trazer as lembranças dos afetos, perde gradativamente a acentuação enfática até beirar o desaparecimento. Em meio ao sopro, um fio da voz decresce seu tônus. Para finalizar, ela recobra a intenção inicial e, numa espécie de mágoa, questionando sobre o seu futuro suspendendo sua fala com a aceleração e acentuação final.

Com isso, convém notar que M1 atinge o quanto antes a máxima tonicidade para caracterizar a violência, enquanto M2 distribui a tonicidade de maneira diversa. $\mathrm{Na}$ segunda encenação, a tonicidade e o andamento são contidos, configurando assim um ritmo que registra maior regularidade e apresenta um crescimento conforme a consecução é processada. Em M2, percebemos um maior distanciamento em relação aos fatos passados, em relação aos quais podemos notar o arrependimento dos 
sacrifícios do passado. Lembremos que a primeira encenação traz uma Medeia em que não notamos essa dimensão. M1 expõe um estado, sua paixão reascende a perturbação sofrida pela ruptura com Jasão e não possibilita a organização das justificativas mais comedidas. M2 distancia-se dessa ruptura e volta-se para um outro passado, não o recente como em $\mathrm{M} 1$, mas o de seu mito.

O afastamento do mote desencadeador da ira, presente na emissão de M2, é também notado quando sua voz perde a tonicidade e velocidade, acalmando-se. No instante tomado como patético M2 volta-se para o público, procurando cumplicidade. Nessa cena, ela não quer convencer Jasão de seu sofrimento para então legitimar seus atos, mas, sim, ela busca o espectador. Quando a impressão é lamentosa, a personagem afasta-se do quadro de embate, voltando-se para outro foco, o que nos permite dizer que M2 apresenta a ira sob aspectos diferentes de M1.

Em M1, a retenção atualiza a motivação de seu estado, na recorrência das irrupções há a intensidade da ruptura inicial e do sentimento de injustiça que precede a ira. A audiência, em M1, pode se compadecer diante de uma personagem desprovida de recursos deliberativos próprios que, com indignação e revolta, é acometido por suas emoções. Já em M2, as motivações estão potencializadas, sob forma de lembranças, que já podem ecoar como rancor, ou mágoa. Esse abrandamento em M2 permite que as causas de seu próprio sacrifício sejam mais narrativizadas do que demonstradas ou figurativizadas, como em M1. A ira de M2 olha para as carências do futuro revelando um desejo de vingança mais intenso.

De maneira estereotipada, M1 apresenta continuamente o primeiro momento da manifestação do pathos, em que este é proporcional ao solapamento da razão. Assim, é proeminente a relação dessa personagem com uma motivação exterior que conduz sua ação e, provavelmente, com o dever. Ao mesmo tempo em que a motivação é externa à concepção do ato funesto, não podemos deixar de observar que seu movimento desesperado reflete o fechamento da personagem sobre si mesma, como se no embotamento das ideias não houvesse outra saída além de acatar a imposição de um destino inexorável. Na segunda encenação, a personagem constrói uma passagem para distensão e abertura de M2, pois a ira será levada a cabo, legitimando o desejo de retaliação e Medeia, em sua autonomia, atualiza uma espécie de querer. 


\subsection{Observações sobre a ira ou a cólera}

No decorrer dos trechos descritos, a personagem em sua primeira versão é observada tanto na procura pelo ponto culminante das intensidades (a tonicidade e o andamento), quanto em certa homogeneidade de um comportamento vocal regrado pela tensão. As constantes rupturas dos fluxos da tonicidade foram tomadas como o componente iterativo necessário para constituição do caráter dessa construção. $\mathrm{Na}$ segunda encenação, a expressão cênica ocorre de modo bastante diverso, pois Medeia 2 apresenta-se na regularidade da disposição dos acentos e, com isso, na configuração de certos perfis rítmicos. A personagem delineia-se por essas constâncias ou essas continuidades que não mais configuram a tensão da ruptura, como em Medeia 1, mas apontam para sua possível distensão.

Com as análises do discurso entoado, as diferentes construções da personagem central promovem também variação de uma paixão em questão, a ira ou a cólera. Para esclarecer como foi possível compreender os papéis assumidos pela atriz ao fazer ressoar em sua voz um determinado discurso, convém retornar brevemente ao tratamento semiótico dado a essa paixão.

De início, em seu exame da cólera, A. J. Greimas ressalta a diferença entre uma perspectiva semiótica e uma orientada pelo princípio clássico de classificação. Assim, a proposta greimasiana reflete sobre uma sucessão de estados caracterizantes dessa paixão que geram programas narrativos. $\mathrm{Na}$ análise em questão, é por meio do reconhecimento dessas unidades que se torna possível recompor as estruturas semelhantes às do modelo elucidado a partir da lexicografia, conforme Greimas o elaborou.

Partindo das acepções do lexema em estado de dicionário, a proposta greimasiana sugere a apreensão de unidades autônomas ou, em outros termos, de motivos que configuram uma tipologia conotativa para composição de papéis patêmicos ou psicológicos. Para tanto, o lexema propõe uma economia ou um esquema de previsibilidade, em relação ao qual o discurso pode ser visto como um modo expandido, produzindo estruturas similares, mas de maneira difusa. Convém destacar que, ao mencionar a sugestão de L. Hjelmslev, Greimas enfatiza a relevância 
do exame das tipologias ou de modelos de previsibilidade para alcançar os objetos da semiótica conotativa (GREIMAS, 1983: 240).

As primeiras acepções do lexema não esboçam a necessidade de uma face violenta para a cólera, conforme Greimas as encontrou na língua francesa. De início, o sujeito sofre simplesmente de uma agitação ou de uma irritação, como um fremir dispendioso de grande energia. Os destinos desse estado são múltiplos, de modo que essa multiplicidade torna a cólera uma paixão complexa, diferindo-a de uma paixão simples como, por exemplo, a avareza definida na expectativa por um objeto.

Com isso, as vicissitudes da cólera são desdobradas a partir da seguinte tríade básica: frustração, descontentamento e agressividade. A frustração surge a partir da ruptura de uma espera. Já essa etapa inicial é um novelo de muitas dobras, pois na espera antecedente à frustração, é possível contemplar seus diferentes tipos: uma delas é a espera de um objeto, a outra é a espera fiduciária. Nessa última, deixamos a antiga oposição entre o sujeito de estado e o sujeito do fazer, para que uma nova seja instaurada entre o sujeito agente e o acometido, condicionados por sua relação com a espera de uma troca, subjacente a um contrato de confiança. Assim, na nova oposição proposta por Greimas, a espera fiduciária difere da espera simples por meio da modalidade do querer, pois quando acometido o sujeito posiciona-se como um sujeito do não-querer.

A relação contratual expõe um destinador do julgamento, que determina a ordem do objeto-valor, e um sujeito de espera e frustração, que crê ter algum direito e se coloca diante da sanção de outro sujeito. Por isso, há ainda os estados coextensivos à espera que aparecem nos desencadeamentos da insatisfação. Observando, por sua vez, a posição conclusiva do programa narrativo da cólera ocorre o gesto violento, ou melhor, a agressividade. Por um lado, Greimas expõe a etapa da vingança como uma necessidade de reequilíbrio entre os sujeitos do contrato. Por outro, o componente da agressividade é concebido como o transformador do estado interno do sujeito em ação externa.

De fato, uma nuance semântica entre a cólera e a ira pode ser aventada, sobretudo, em relação ao ponto final da sucessão. A agressividade da cólera seria mais 
amena que a da ira? Ira e cólera teriam o mesmo grau de intensidade? No dicionário grego-francês Le Grand Bailly, orge em grego é traduzida por colère, já em português traduzimos o grego igualmente por cólera ou ira. Já na Retórica das Paixões, de Aristóteles, observamos que a lógica da orge é apresentada mediante a mesma noção de ruptura de um estado original que, no lugar de frustração, os antigos preferem chamar de desgosto, como um sofrimento gerado pelo desprezo desmerecido (desdém, difamação e ultraje) (ARISTOTELES, 2003: 7-15).

Assim, vemos que o problema em delinear uma paixão não está na sua classificação, mas no reconhecimento dessas etapas internas ao percurso na conformidade dos discursos. Pois, de modo semelhante, para Aristóteles, a vingança é pressuposta pela ira, mesmo que a violência desenvolva-se na imaginação do encolerizado.

No exame da cólera das personagens encenadas, é importante destacar que sua matriz sintática e narrativa é passível de transformação quando flexionada pelos discursos. Mas, de maneira geral, os programas narrativos internos à ira ou à cólera podem ser observados a partir da intensidade da espera, sua etapa inicial, ou da intensidade do descontentamento que, por sua vez, também recebe investimentos aspectuais, apontando diferentes destinos para as espécies de insatisfação. Consideramos, portanto, que a ira ocorre quando há “(...) esperanças não realizadas, acidentes imprevistos e rupturas no curso supostamente normal das coisas suscitam o arrebatamento. Em suma, ficamos irritados com as rupturas das identidades." (ARISTOTELES, 2003: XLIII - XLIV).

Essas considerações auxiliam no julgamento das encenações de Medeia. Sem dúvida, a primeira encenação exorbita na demonstração da agressividade e da violência, de modo que esse fato pode ser interpretado tanto como etapa inicial quanto como final dessa paixão. Contudo, ressaltamos que a "ruptura da identidade" está voltada, sobretudo, para a ênfase nos gatilhos desencadeadores do percurso narrativo da ira e, assim, na espera de Medeia por um direito que Jasão deveria cumprir. Na segunda encenação, Medeia 2 parece atonizar a ruptura, dando intensidade ao descontentamento que, além disso, torna-se durativo. Abaixo, o quadro sintetiza as avaliações laboradas até então. 


\begin{tabular}{l|l|l|l}
$\begin{array}{l}\text { Personagem } \\
\text { encenada }\end{array}$ & Medeia 1 & Medeia 2 \\
\hline \hline PN da Ira & $\begin{array}{l}\text { Intensidade da } \\
\text { Espera }\end{array}$ & Contrariedade & $\begin{array}{l}\text { Intensidade do } \\
\text { descontentamento }\end{array}$ \\
\hline \hline $\begin{array}{l}\text { Modalização da } \\
\text { ação violenta }\end{array}$ & Sujeito acometido (não-querer) & Sujeito agente (querer) \\
\hline \hline
\end{tabular}

$\begin{array}{llll}\text { Tensividade Atualização da ruptura Atualizãão da prossecução } & \text { Atua }\end{array}$

\subsection{A dissimulação}

$\mathrm{Na}$ cena anterior a esta que agora iremos examinar, Medeia revela o ardil pelo qual pretende se vingar. A tragédia aproxima-se da catástrofe. E, em forma de aparte, como na segunda encenação, ou contando ao coro, como na primeira, a protagonista compartilha com o espectador o momento de dissimulação seguinte, quando Medeia convence Jasão de seu arrependimento. De um lado, essa cena representa o momento de contrato entre os antagonistas em cena. De outro, ela aproxima o espectador de conteúdos velados na atuação da personagem. Pois, como reconhecer a dissimulação sem que ela seja perscrutada? Neste estudo, procuramos por meio dos investimentos tensivos as nuances da manipulação, da coerção, ou da sedução, junto ao aparecimento das modalidades e dos papéis patêmicos e cognitivos.

A seguir, o texto lembra a característica ardilosa da irascível Medeia, encoberta sob a aparência do arrependimento.

Perdoa-me, Jasão? Peço-te indulgência por tudo aquilo que disse. Perdoa-me os meus arrebatamentos quase sempre desvairados, compensando-os generosamente se possível as provas de afetos que no passado sempre e que de maneira ou de outra procurei lhe oferecer. 
Pensei e pensei, troquei palavras comigo mesma e só então me dei conta da grande injustiça que estava cometendo. Desgraçada de si como podes Medéia sustentar tamanha má vontade, tamanha animosidade, tamanha fúria, contra aqueles que querem realmente te estender a mão? És cega? És louca por acaso? Perdoa-me, Jasão, de coração? Eu não tive como em sã consciência rebater aqueles seus arbítrios francos, conscientes, prudentes. Então, como estive tão contra os governantes de Corinto e contra ti contra as bodas do casamento. Agora vejo claramente uma prole de irmãos aos meus filhos, dando-lhes no futuro segurança desejada e também realeza. Como? Embora, não possas me perdoar, não sei se mesmo eu poderei me perdoar de tão impensadas atitudes. Sempre fui cabeça dura bem sabes.

A primeira observação a ser feita deve ser colocada em relação à manipulação em jogo. Afinal, esse episódio expõe Medeia como alguém que deliberadamente manipula Jasão. Como preliminar ao contrato de confiança entre Medeia e Jasão, é necessário notar os estatutos do ser e do parecer de Medeia, à qual se pode confiar a sinceridade do arrependimento. Assim, a manipulação tem por primeiro objetivo conquistar a adesão do destinatário, para que se complete uma etapa do plano funesto da protagonista. Confiando em Medeia, Jasão aceita os presentes mortíferos oferecidos à princesa de Corinto, prometida como sua noiva.

A segunda observação está no tipo de estratégia de manipulação, a sedução. $\mathrm{Na}$ persuasão, Medeia valoriza as qualidades de Jasão, de modo que o manipulado possa exercer um fazer interpretativo favorável, julgando tanto suas próprias competências, quanto as de sua esposa. Desse modo, Jasão é convidado a pensar por duas vezes. Primeiramente, "será que devo confiar em Medeia, ela está sendo sincera quanto ao seu arrependimento?" Depois, "será que sou franco, consciente e prudente, como ela diz?"

Medeia age com dissimulação, esconde sua ira sobre outra aparência, pois diz estar arrependida de seu rompante enfurecido e compreender a nova situação que the foi imposta. O questionamento sobre sua sinceridade é colocado na medida em que o julgamento do destinatário não é eficaz, ou melhor, seu engano o levará a uma trajetória de particular infelicidade. Assim, avaliamos ambas as encenações em relação 
à suspensão do saber de Jasão, de modo que na comparação entre as diferentes encenações as competências cognitivas de Jasão oscilam entre a extinção do conhecimento e certo restabelecimento de seu valor positivo.

A tensão da cena está na espera que Jasão reconheça as qualidades letais de Medeia, ou seja, o esposo pode reconhecer a característica mais constante de sua companheira, a ira. Como espectadores, podemos almejar que ele compartilhe de nosso saber. Nesse sentido, as circunstâncias o expõem como destinatário marionete, que cumpre sua função como parte da trama que Medeia elabora como destinadora e sujeito.

De um lado, Medeia pode ser vista como quem atua na persuasão a partir da intrusão de um observador externo. O espectador, fora de cena, é então incorporado ao drama por adquirir o saber necessário na passagem anterior, fazendo o juízo do que the é apresentado na interação encenada entre destinador/enunciador e destinatário/enunciatário. De outro, se isolamos os membros da cena, Jasão é tomado como um destinatário que credita confiança. Assim, haveria certa empatia entre o espectador e o enunciatário encenado, pois ambos cumprem o papel de destinatário diante de Medeia. A dissimetria interna a esse múltiplo destinatário é colocada na programação dos papéis cognitivos e patêmicos de Jasão, como vemos nos gradientes tensivos particulares de cada encenação dessa cena. Assim, se a plateia tem um saber que falta a Jasão, é provável que ela se enquadre melhor na função de destinador julgador.

Anteriormente, Medeia já havia revelado que apresentaria "tudo o que Jasão quer ouvir", ou seja, a estratégia de amplificação ou aliciamento seria dominante na elocução. Conhecendo bem seu adversário, ela tenta atingir sua fragilidade moral, a vaidade, certamente ignorada por ele. Como mencionamos, Medeia atinge um saber que de antemão não seria compartilhado. $\mathrm{O}$ argonauta jamais reconheceria a si mesmo como homem arrogante e vaidoso, ferindo assim sua própria honra. A manipulação obtém a adesão de Jasão como sujeito que não sabe nem de si mesmo, nem do encadeamento narrativo que Medeia dissimula. Em outras palavras, a eficácia dessa persuasão depende da ignorância do sujeito e de sua disposição para confiar: de um não-saber e de um crer. 
Jasão está programado para não desconfiar, pois não sabe, ou não quer saber. A maneira como isso ocorre é percebida nas oscilações das modalidades do crer e do saber. Em cada encenação, essas modalidades são construídas de maneira diversa. Por sua vez, o público participa da encenação, acompanhando as mentiras de Medeia. Do ponto de vista da audiência, M1 não parece arrependida e não está, enquanto M2 parece possuir a qualidade do arrependimento, mas não está. Isso reforça que o público exerce o julgamento que Jasão deveria exercer.

A relação de confiança é notada na sedução articulada em um pedido de indulgência. Esses enunciados articulam o concedível, entre o aceitável e o tolerável, mediante a generosidade do destinatário que avalia o mérito da suplicante. Para tanto, Medeia valoriza as competências de Jasão, contrapondo o reconhecimento das suas próprias fraquezas. Nesse instante, em que ela diz ter pensado demoradamente, suas reflexões internas surgem na forma de discurso direto. Essa mudança traz outro elemento para a potencial veridicidade da elocução da personagem, provocando o efeito de objetividade na enunciação de seus pensamentos.

$\mathrm{Na}$ primeira encenação, o espectador toma Medeia pela falsidade de seu arrependimento, de tal modo que Jasão é observado como quem acata as solicitações de M1. Assim, o exagero do elogio amplia também o fato de que Jasão não atua como quem pode saber das intenções de M1. Com a participação de um observador externo, o espectador, esse quadro apresenta a confiança de Jasão como uma característica de sua estupidez. Desde o princípio do pedido de perdão, a voz expõe M1 em estado de absoluta subordinação, como pode ser percebido no alongamento no início e no final do segmento, acrescida de uma curva sinuosa entre os acentos finais. Esses extremos são compartilhados na interlocução entre palco e plateia. Assim, na primeira encenação, o público toma o elogio da superioridade de Jasão como falso, pois Medeia não parece estar arrependida e, de fato, não está.

M1 transita pela dubiedade da ironia ou da farsa. Ao interagir com o público, a protagonista faz surgir uma espécie de narrador que comenta a situação por meio da gestualidade corporal e vocal. Esse distanciamento entre o que é dito e a maneira de dizer altera também o modo como Jasão pode ser percebido, uma vez que o conteúdo verbal expõe qualidades que os gestos contradizem. Com isso, a exaltação do 
enunciatário, promovida pela sedução, é aos olhos do espectador também a confirmação da sua ignorância e da sua ridicularização. Quanto mais ele confia em M1, mais demonstra as fraquezas que permitem sua manipulação. Na primeira encenação, Jasão detém de tal forma o não-saber que recai em certa ingenuidade, promovendo a aceitação completa, como se acatasse a solicitação de Medeia independentemente das circunstâncias.

No registro do tônus e das acelerações excessivas, o caráter hiperbólico da entoação de M1 transformará a situação da dissimulação em algo quase farsesco. Como na farsa, há a geometria angulosa dos gestos, representando grandes tipos humanos (a loucura, a ingenuidade, etc.) e o distanciamento do narrador, ou simplesmente o efeito de triangulação entre este último, a cena e o público. Esse regime de atuação, que caracteriza a comédia, traz excessiva ambiguidade à intenção de valorizar Jasão. Isto é, a demonstração de que tudo não passa de um engodo divide a cena, transformando a relação de interação entre Medeia e Jasão no lugar da crença no inconcebível. Na primeira encenação, esse paradoxo do crer é explicitado na atuação exacerbada.

Na segunda encenação, com as razões da manipulação mantidas em segredo, parece surgir um Jasão mais tolerante, vítima de engano inevitável. O elogio moderado pode apresentar em sua configuração a permanente possibilidade de desconfiança na interação, ao mesmo tempo em que a veracidade e a sinceridade legitimam-se mediante essa atuação mais comedida. Assim, a eficácia da sedução em M2 avalia a possibilidade de presença do saber do enunciatário.

M2 coloca-se de maneira mais solene. Sua dissimulação é apresentada com calma, contrapondo-se à ira, promovendo a tolerância do destinatário, capaz de certo razoamento. A entoação de M2 revela uma sinuosidade de alturas que procura curvas descendentes. Ao contrário da tonificação de M1, M2 explorará o agravamento do timbre, trazendo mais nobreza para a clemência, do que ironia e desprezo pelo interlocutor, sendo essa avaliação dividida com o público. M2 explora ainda a acentuação das pausas, ao trazer o discurso direto, voltando-se para o momento de ponderação que a reflexão anuncia. Os silêncios enfatizam neste caso a alteração para o discurso direto. Já M1 está sempre entre a súbita interrupção e a retomada das suas 
acelerações, não direcionando os detalhes dessas passagens. A demonstração do discurso interno em forma direta realizada por M1 é transformada em mais um arroubo.

Se Medeia não tivesse nos revelado suas intenções, não saberíamos que M2 está mentindo ou escondendo sua ira. M2 dissimula como quem fala a verdade, pois parece estar arrependida. Por sua vez, M1 revela-se ao público. Em M1, esse observador é acometido pela falsidade da situação. Já em M2, essa cumplicidade da audiência é mobilizada por outra ordem. De um lado, em M1, a crença de Jasão pode ser digna de piedade, tamanha é sua pobreza moral. De outro, em M2, é ainda maior a indignação da plateia diante daquele que parece simplesmente ter esquecido as qualidades de uma mulher que um dia lhe foi necessária. De maneira geral, Jasão é concebido na ausência do reconhecimento e das lembranças que o permitiriam constatar tanto a fidelidade de Medeia no passado, quanto sua face irascível. Mas, diante da segunda encenação, para a aflição dos ouvintes, ele está condenado a acreditar, pela incapacidade de reconhecer o caráter de sua esposa.

O quadro abaixo procura resumir parte das modalidades e dos papéis assumidos, conforme a avaliação até o presente momento dessa análise.

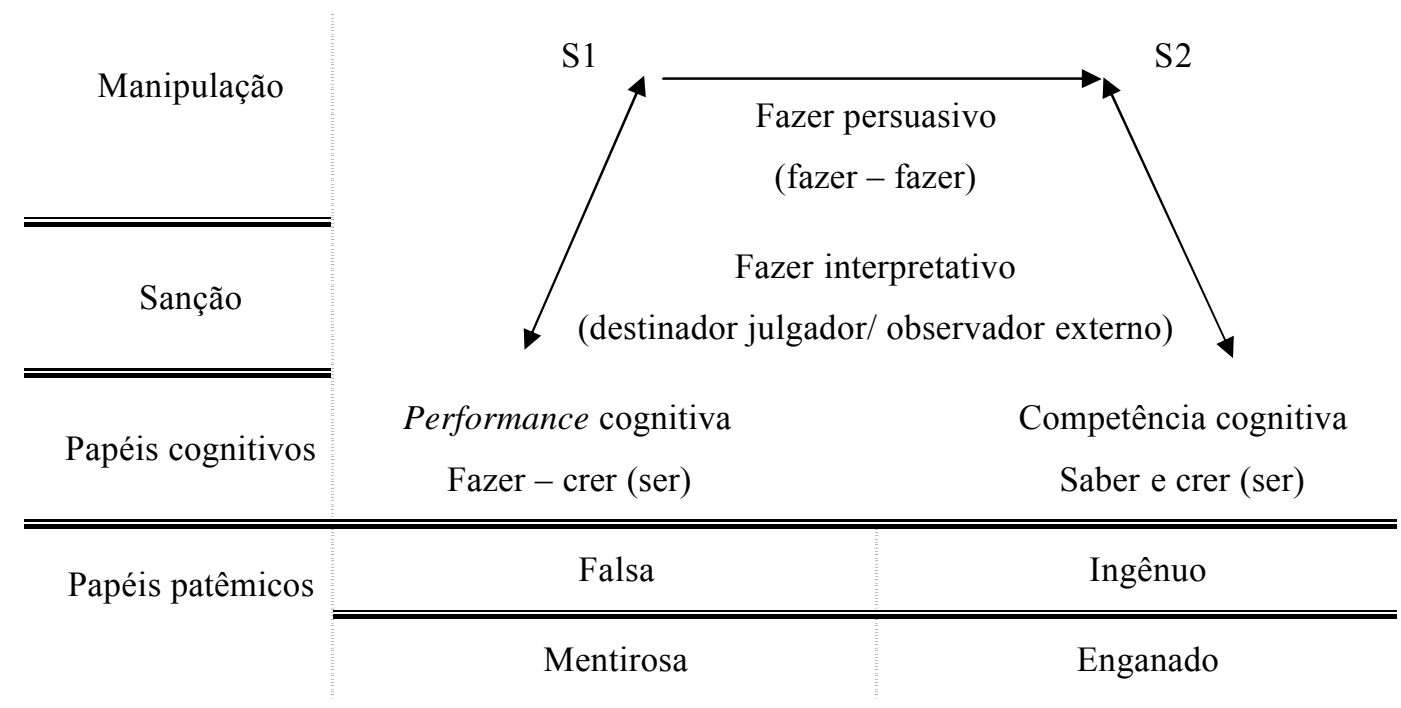


De acordo com o ponto de vista do observador externo, o fazer persuasivo de M1 faz-crer no arrependimento, transitando sob o eixo dos subcontrários das modalidades veridictórias, como destinadora que seduz por meio da falsidade, pois não parece e não está arrependida. Com a observação das características de quem é falso na relação de destinação colocada em cena, Jasão pode ser visto como quem crê em algo que não é crível, de modo que é percebido numa gradação entre ingenuidade e estupidez.

Em M2, o deslizamento sob as modalidades veridictórias enfatiza duas de suas qualidades. Por um lado, mobilizando a dêixis positiva do ser e do parecer na característica mais constante de Medeia, a protagonista é irascível, embora não pareça irascível. Por outro, no julgamento de seu caráter transitório, M2 mobiliza a mentira ao parecer estar arrependida. Como contrapartida, o Jasão dessa encenação pode saber, mas é enganado. 


\section{A voz do coro}

Nesta próxima análise sobre a expressão vocal do coro nas encenações de Medeia de Antunes Filho, o objetivo principal é esquadrinhar as consequências da projeção da entoação no processo de significação da encenação. Para tanto, introduzimos algumas noções sobre esse componente trágico e, em seguida, comentamos sobre o contexto de seleção do corpus. Então, partimos para o detalhamento do comportamento vocal que, como nas outras análises, surge com suas recorrências e participa do gerenciamento global de tensões e repousos da encenação.

Para o detalhamento dos perfis entoados, partimos do pressuposto que a entoação pode ser tratada como um discurso projetado sobre as unidades lexicais. Por isso, consideramos que as amostras dos coros em Medeia teriam especial importância, pois elas trazem uma unidade comum em relação a qual o discurso vocal pode ser percebido como um objeto relativamente autônomo, sendo rapidamente identificado pela audiência.

Selecionamos a cena da súplica e observamos como a intensidade do apelo problematiza o ápice catártico da encenação. Continuamente esperada como a plenitude de um acontecimento e de um instante de maior tensão, a catarse trágica e o ato funesto em Medeia realizam-se como uma resultante da contenção e sobre as qualidades diversas do temor e da piedade, paixões relevantes para entendimento da voz coral e de seu papel na interação com a protagonista.

\subsection{O papel do coro e o movimento catártico}

Nos primórdios da tragédia, a figura legendária de seu criador, Téspis, é seguida por outras mais conhecidas. Ésquilo introduz o segundo ator, Sófocles, o terceiro e Eurípides é reconhecido por sua reinterpretação radical dos mitos. Cada tragediógrafo, 
com a elaboração de suas formas artísticas, propiciava determinada eficácia dramática, levando o público ao expurgo catártico (MAGALDI, 2008).

Antes da transformação promovida por Ésquilo, a tragédia ocorria na oposição entre o canto coral e a fala do papel individual ou, então, do protagonistés que conduzia, por estar à frente, o agón.

Polaridade, portanto, entre dois elementos na técnica trágica: o coro, ser coletivo e anônimo cujo papel consiste em exprimir em seus temores, em suas esperanças e julgamentos, os sentimentos dos espectadores que compõem a comunidade cívica; personagem individualizada cuja ação forma o centro do drama e tem a figura de um herói de uma outra época, a quem é sempre mais ou menos estranha a condição normal do cidadão. (VERNANT e VIDALNAQUET, 1999: 2)

De maneira geral, o papel do coro é definido na sua interação empática com a protagonista e, em determinado ponto, essa interação é dúbia. Essa dubiedade consiste em poder assertar sobre o valor de seus enunciados ao passo que se desenrola a ação e, com isso, a função dramática dessa personagem. Nesse sentido, a participação do coro no cumprimento da ação pela protagonista parece ser construída de maneira indireta. Quer dizer, ele distancia-se do herói, comentando os fatos, e aproxima-se dele compartilhando seus sentimentos, porém não pode impedir o curso de seu destino inexpugnável.

Há uma espécie de consenso entre os estudiosos helenistas que encontra no coro a função de representação do senso comum seja pelo distanciamento de sua observação, seja pela aproximação da paixão sofrida pelo herói. Os primeiros desses componentes posicionam o coro como um julgador dos acontecimentos, à medida que o pathos trágico ocorre pela necessidade ou fatalidade do ato funesto diante do qual não se pode fugir. Enquanto a alética ou a deôntica promove a progressão dos fatos, o coro tenta impedir a chegada da catástrofe.

Nessa oposição clássica entre a personagem protagonista e a antagonista, o coro “deve participar da ação" (ARISTOTELES, 1973: 506). Através de suas súplicas e de 
seus lamentos, na expressão do temor e na ponderação das advertências, o coro é o antagonista que confronta o protagonista com suas interpelações (PAVIS, 2005: 280). Junto a outro elemento espetacular, a polarização entre o coro e a personagem individual aparecia na chamada melopeia, entre o lirismo do coral e a métrica do herói construída para se assemelhar à prosa.

Provavelmente oriundo da tradição lírica em que os feitos heroicos eram glorificados, o coro trágico não mais elogia esses feitos. Na tragédia, ele é o primeiro emulador que a protagonista enfrenta e, em decorrência disso, o herói transforma-se em imperfeito. Assim, nas mais variadas formas de interpelação, as intervenções corais não alteram o curso da ação, pois sua advertência não pode mudar o destino inexorável. Dito isto, o coro cumpre o papel de opositor, ao mesmo tempo em que julga o desenrolar da ação e representa, com isso, a cidade que revê suas tradições.

A importância dessa personagem coletiva e impessoal é encontrada na incorporação dos sentimentos possivelmente compartilhados com o público por meio dessas intervenções apelativas ao herói. Por esse mesmo jogo que instaura uma relação entre o drama e a audiência, é possível compreender o efeito que visa à purificação de certas emoções, o que foi considerado já nas primeiras análises desta arte. "A tragédia tem por efeito específico a catarse das emoções de terror e piedade" (ARISTOTELES, 1973: 505). ${ }^{16}$

Encontrada no Dicionário de Semiótica, a definição para o temor (crainte) comporta o querer do antagonista:

Oposto a desejo, temor não é, do ponto de vista semântico, um nãoquerer, mas um querer contrário, que só se interpreta no interior de uma estrutura sintática que postule a reciprocidade de sujeitos

\footnotetext{
${ }^{16}$ Em português, segundo o dicionário Houaiss, o terror abarca as qualidades do que amedronta e é terrível, gerando sinônimos como, por exemplo, espanto, horror e pavor. Em grego clássico, conforme o dicionário Le Grand Bailly, há uma diferença entre os lexemas fobos e deinos, o que traduzimos simplesmente por terror ou temor. O fobos é o medo que faz fugir e o deinos é o que paralisa. A qualidade acelerada em fobos, em contraponto com o alongamento do espanto em deinos, é praticamente esquecida e, assim, o terror parece somente a intensificação do medo. As qualidades podem ser variadas de acordo com a tonicidade e a aceleração, tendo como um princípio comum o espanto e sua subtaneidade.
} 
antagonistas (sujeito/anti-sujeito). (GREIMAS e COURTÉS, 2008: 500)

O papel do coro e a coletividade por ele representada compartilham de sentimentos antagonistas e dependentes. Em resposta à paixão que acomete o herói e à modalização de seu ato, as paixões do temor e da piedade com suas qualidades diversas são expurgadas. Por exemplo, quando Medeia, motivada pela ira, encontra a coragem para matar os próprios filhos, o coro teme e pede por piedade para que isso não aconteça.

Nas análises seguintes, com o exame dos coros nas encenações de Medeia, procuramos avaliar os ápices da tragédia e as variedades qualitativas no expurgo das emoções representadas pelo coro, tendo em vista que a culminância da tragédia ou o momento de maior tensão é geralmente avaliado como momento catártico. Para tanto, selecionamos uma cena para descrição da fala do coro, em que esse ápice é problematizado.

\section{$6.2 \mathrm{O}$ contexto de seleção do corpus}

Percorrendo as encenações das tragédias de Antunes Filho, assistimos às diferentes possibilidades de criação cênica desse componente trágico. Na organização dessa unidade espetacular, o coro é identificado a partir de um traço muito simples. Inevitavelmente, ele surge na manifestação da coletividade ou, simplesmente, da aglomeração de pessoas que fazem ressoar uma mesma voz no espaço cênico. Todavia, as encenações diferenciam-se uma das outras por suas formas de expressão para configurar esse elemento esperado e para transformar as nossas expectativas.

Esperamos encontrar no coro as vozes unissonantes e o bloco humano caminhando em sincronia numa mesma direção. Entretanto, nos diversos coros encenados por Antunes, a emissão em concordância torna-se uma ideia a ser retrabalhada e a invenção da espacialidade e das temporalidades é interpelada em cada projeto estético. 
Em Fragmentos Troianos do mesmo encenador, por exemplo, o coro também se fragmenta. Diferentemente do uníssono, a fala é distribuída entre as atrizes. A sincronia desse coletivo é alcançada ao sequenciar rapidamente as partes de uma proposição, sem deixar que as interrupções de cada emissão resultem na quebra do andamento. A totalidade do coro deve ser reconstituída pela audiência a partir da polifonia que, no entanto, respeita as singularidades dos timbres de cada uma de suas partes. Outro exemplo, bem diverso, é encontrado em Antígona, que apresenta um coro feminino e outro masculino. O coro feminino geme, desnudando-se em torno de certo Dionísio. Já o coro masculino é enfim aquele que profere o texto de Sófocles. Diante dos diferentes exemplos, o coro feminino de Antígona pode parecer o resultado da maior reflexão e extrapolação interpretativa sobre a tragédia.

Assim, as encenações elaboram seus processos de significação, procurando na plasticidade das matérias não somente um revestimento adequado aos componentes fundamentais, como também a renovação das prescrições poéticas. Com isso, sabemos que não é possível exaurir a compreensão desse tipo de personagem, em decorrência da brevidade dessa primeira incursão analítica sobre esse campo. Por isso, voltamos às encenações de Medeia.

\subsection{Os coros em Medeia e suas intervenções na tragédia}

Em linhas gerais, nas encenações de Medeia de Antunes, os coros exploram sobretudo a possibilidade de emissão vocal unissonante. A entoação conjunta garante que as quebras dos registros individuais das participantes dos coros não sejam marcadas e, ao contrário disso, eles dissolvem-se no uníssono. Como uma resultante da emissão coletiva, o timbre parece ser mais homogêneo do que na voz de um indivíduo.

Na primeira encenação, Medeia 1, o coro permanece em cena, movendo-se pouco pelo palco. Coberto com uma lona preta, ele permanece na maior parte do tempo do lado esquerdo do palco. Dez mulheres compõem o coro dessa encenação. Enquanto o coro está encoberto, Medeia dialoga com outras personagens. Depois, ela expõe seus pensamentos para o coro. Esses apartes marcam as entradas e saídas das 
demais personagens. Já na segunda encenação, Medeia 2, o coro permanece menos em cena e tem maior mobilidade pelo espaço. A possibilidade de flexibilidade e locomoção decorre do fato de que esse coro possui entre quatro e cinco mulheres. De mesmo modo, a emissão vocal tem maior elasticidade especialmente em relação ao uso das alturas.

De maneira geral, na relação com a trama fabular, as intervenções do coro preenchem os espaços entre os episódios com as entradas e saídas das outras personagens que representam indivíduos (o rei de Corinto, Jasão, Egeu e os mensageiros). As falas do coro marcam as passagens e, dependendo da contagem de cenas, aparecem nas cenas ímpares ou intercalares dos diálogos entre Medeia e uma segunda personagem, presentes nas cenas pares. Elas alinhavam o percurso narrativo, seguindo a protagonista. O coro comenta a ação, narra os fatos do porvir, faz súplicas e lamentações. Como uma primeira impressão, a emissão traz grande intensidade a qualquer uma dessas situações sugeridas pelos enunciados.

No início da peça, o coro aparece fragilizado pelos gritos de Medeia. Solidário e preocupado, ele quer saber "o que está acontecendo". Essa primeira cena é seguida pela entrada do Rei de Corinto, em que Medeia é expulsa da cidade com seus filhos. Ela implora por mais um dia na cidade e, mesmo a contragosto do rei, recebe esse tempo. Então, o coro lastima "mulher, infeliz mulher". Egeu, rei de Atenas, surge de passagem para consultar o oráculo e, enfim, descobrir por que ele não pode procriar. Medeia promete ajudá-lo neste caso com suas poções e feitiçarias e, em troca, ela recebe a garantia de asilo.

Medeia conta detalhadamente seus planos ao coro. Em primeiro lugar, ela tem de convencer Jasão de seu arrependimento, para que a princesa de Corinto aceite como presente o manto e a coroa envenenados. Em segundo lugar, tendo precipitado as primeiras imolações, ela jura matar os próprios filhos. O coro procura evitar tão grande horror, repreendendo Medeia, enquanto ela revela o que se seguirá. Em seguida, Jasão sofre a manipulação planejada por Medeia. Com Jasão iludido, a catástrofe aproxima-se. Sem esperanças, o coro pontua que não há mais como contrariar a realização dos assassinatos. O horror constrói-se progressivamente. Após esse lamento, o desespero é maior e, numa espécie de ápice da ação trágica, as 
entradas e saídas de personagens trazem notícias contrastantes. As intervenções dos mensageiros aceleram a chegada ao final do espetáculo.

Os mensageiros contam notícias diversas. O primeiro traz um motivo de alegria, falando sobre a possibilidade de permanência dos filhos em Corinto. O segundo relata a morte da princesa e do rei, descrevendo detalhadamente todo o sofrimento. Depois de escutar as notícias, Medeia comete as piores imolações e foge.

Então, Jasão surge e pergunta ao coro “onde está Medeia?”. O coro é o informante da morte das crianças pelas mãos da própria mãe. Jasão procura por Medeia, mas ela já parte no carro do Sol, pai de seu pai. É tarde, Jasão não pode nem mesmo enterrar os corpos das crianças. A ação central da peça pode ser tomada como terminada. O que resta é muito pouco, uma última cena avaliativa está guardada para o coro. Ele roga aos deuses, para que os homens não sejam assolados pelo horror como esse trazido pela tragédia.

\subsection{Análise dos coros}

Nas análises dos coros, procuramos acompanhar a transformação da expressão sonora em seus possíveis conteúdos. Com isso, vislumbramos a apreciação das formas artísticas e, especificamente, das escolhas estéticas relativas à voz munidas intencionalmente de sentidos.

Selecionamos a cena da súplica em que o aparecimento da intensidade problematiza os ápices dos espetáculos e a catarse sugerida por eles. Para observar as qualidades das culminâncias tensivas, nosso ponto de partida é a entoação e, no geral, o comportamento vocal derivado dessas particularidades entoadas. Contudo, logo essa perspectiva é desdobrada. Isto é, os tipos de aparecimento das acentuações, das ascendências e das descendências na modulação tornam-se recorrentes, perpassando tanto a atuação das personagens quanto as encenações.

Examinamos a cena da súplica em três etapas. Primeiramente, situamos questõs da súplica pertinentes em ambas as encenações. Depois, analisamos detalhadamente os trechos das entoações em cada encenação. E, por fim, comparamos essas maneiras de 
dizer e, com isso, procuramos explicitar os diferentes efeitos de sentido ao entoar o referido trecho. Em relação à segunda etapa da análise da súplica, expomos o delineamento dos componentes sonoros em seus tipos de aparecimento, estabelecendo dependências entre a voz e as unidades lexicais. Embora essa ocorrência simultânea possa ser amplamente desdobrada no nível da análise, procuramos uma medida econômica para a operacionalização desse estudo.

Seguimos para o momento comparativo entre os coros, pressupondo que os comportamentos vocais possam ser reconhecidos não somente nos segmentos que demonstram as diferenças entre as composições, como também na homogeneidade do discurso da personagem e nas relações que estabelecem sua função no drama.

\subsubsection{A Súplica}

Indicando a chegada ao término da primeira metade da tragédia, essa cena explicita as motivações da protagonista e a oposição do coro que, em súplica, brama contra o horror. Essa intervenção ocorre entre a cena com Medeia e Egeu, rei de Atenas, e a cena de dissimulação. Nesse ínterim da progressão dramática, os planos de cometer uma série assassinatos são compartilhados, quando Medeia apresenta os elementos para o cumprimento dos atos. Esse ápice do drama constitui-se na contenção da ação que o coro procura exercer.

No percurso narrativo, essa cena é aquela que traz o conjunto de competências acumuladas para que as imolações sejam realizadas. Isso porque salvaguardada por Egeu e com a garantia de asilo, Medeia "tem agora seu refúgio" e, com isso, ela pode seguir no curso fatal. Manifesta, então, o ardil e seu sofrimento diante do dever de matar os próprios filhos. A protagonista diz: "tenho que matá-los", enquanto o coro interfere: "não faça isso! (...) Pelas leis que regem os mortais.” Medeia articula a vingança a um dever supremo, pois "existem outras leis", e uma obrigação individual, reforçando a noção da quebra de seu contrato com Jasão, um "mal pagador". Na tentativa de reverter o percurso narrativo e passional da protagonista, o coro procura intervir no drama com a interpelação implorativa. 
Todos esses elementos são importantes para compreender como a cena da súplica foi diferenciada em cada encenação. Primeiramente, consideramos que, no enunciado comum, válido para ambas as concepções estéticas, essa cena surge com um ápice relacionado às modalidades tradicionais (poder/dever/querer - ser e fazer) condicionantes das imolações. Assim, a culminância pode ser vista na decorrência dos elementos apresentados verbalmente que instauram a tensão entre o dever-fazer da protagonista e o não dever-fazer evocado pelo coro. Depois, notamos a intensidade da inflexão vocal de cada coro.

Nesse nível de pertinência, o enunciado já explicita o jogo de forças entre os episódios que constituem uma economia global das tensões dentro dos espetáculos. Nessa cena, o coro procura realizar com suas falas uma intervenção na ação de Medeia. Gritando "não, não", o coro implora e tenta manipular a protagonista em nome da humanidade, da consciência e das leis supremas, para que Medeia não execute os próprios filhos.

Contudo, a avaliação de um único ápice em Medeia não é patente. Se considerarmos que o clímax ocorre com a efetividade da ação, no momento da súplica, o ato é ainda o esperado. E, assim, outros momentos podem também ser revelados como ápices sejam nas imolações somente entrevistas no relato do mensageiro, seja no desfecho avaliativo proferido pelo coro. O choque do horror é interceptado nas cenas de nove a onze (conforme Apresentação do corpus) que passam em andamento ligeiro e entrecortado por notícias contrastantes.

Em ambas as encenações, observando a articulação entre a expressão sonora e a progressão dramática, a súplica é a maior culminância da tonicidade utilizada na fala da personagem coral, embora a grande tonicidade não indique ainda a execução da ação fatal programada. Antevemos, por fim, o acontecimento funesto. O gesto vocal intensifica-se na contenção dessa ação, como um grito, inscrevendo-se junto ao transbordamento das motivações vivenciadas pela protagonista.

Em cada uma das falas do coro as espécies de súplicas foram elaboradas. Desse modo, temos duas dimensões comuns às encenações. A primeira é a presença das modalidades alética e deôntica. A segunda é a presença do pathos trágico, ou melhor, 
da valorização do temor, ao lado da esperança trazida pela súplica. De maneira geral, o coro configura a imposição de um dever social, insuficiente para romper a trajetória de Medeia.

No exame seguinte, aprofundamos a análise de uma das partes dessas cenas. Acreditamos que uma observação concentrada possa demonstrar as diferenças entre os discursos e os percursos propostos pelas vozes dos coros encenados. Ocupamo-nos em particular do seguinte trecho, que transcrevemos do material em audiovisual:

Como é que Atenas, a cidade dos rios sagrados, o país que honra seus amigos, poderá acolher a assassina dos próprios filhos? Com toda força te suplicamos, deixa com vida os pobrezinhos. Quando as crianças se ajoelharem suplicantes à sua frente, não terás coragem suficiente de manchar as mãos em sangue tão inocente. Ao olhar os olhos dos próprios filhos, não persistirá na impiedosa intenção. Não conseguirás olhá-los e presenciar sem lágrimas tão profundo martírio. Não pratiques ato tão hediondo em sangue do teu sangue, Medeia.

\subsubsection{Da primeira encenação (M1)}

A partir do aproveitamento da tonicidade, localizamos quatro mecanismos entoativos inscritos conforme a sequência abaixo. Buscamos assim expor como os procedimentos vocais sugerem uma progressão da intensidade na relação com as unidades linguísticas desse trecho.

1)

Como é que Atenas, a cidade dos rios sagrados, um pais que honra seus amigos, poderá acolher a assassina dos próprios filhos.

2)

Com toda força te suplicamos, deixa com vida os pobrezinhos. Quando as crianças se ajoelharem suplicantes à sua frente, não terás coragem suficiente de sujar as mãos com sangue tão inocente.

3) 
Ao olhar os olhos dos próprios filhos, não persistirá na impiedosa intenção. Não conseguirás olhá-los e presenciar sem lágrimas tão profundo martírio.

Não pratiques ato tão hediondo em sangue do teu sangue.

O primeiro dispositivo decorre do aparecimento específico da tonicidade em sua forma dinâmica, em seguida é acrescentada a tonalização pontual com a elevação da altura. Assim, no final dessa sucessão, o fluxo ganha volume e o tom é elevado. Além desses componentes, a variação da velocidade é gradual, à medida que o andamento acelera progressivamente para o término desse mecanismo.

$\mathrm{Na}$ composição do segundo dispositivo, um agravamento breve inicia essa progressão que se caracteriza pela tonicidade estável e permanente por todo o excerto. No primeiro momento, ela surgia como uma dinâmica crescente e, agora, nesse momento, ela estabiliza-se como uma força constante.

A terceira construção propõe um agravamento do tom perpassando todo o trecho e o abrandamento da tonicidade. Em relação ao contraste entre tônico e átono, esse período pode ser considerado atonizado. Desse modo, a intensidade não é mais nem uma dinâmica crescente, como no primeiro dispositivo, nem uma força estável, como no segundo, mas ainda aparece pontualmente como uma ênfase.

Na passagem entre o terceiro e o quarto excerto, há uma mudança brusca na tonicidade, do menos para o mais intenso, e na tonalidade, do grave para o agudo. $\mathrm{O}$ quarto mecanismo volta ao uso da força estável, acrescentando a elevação do tom por toda a extensão de seu período.

Globalmente, a marca predominante da modulação vocal desse coro é a variedade da tonicidade. Primeiramente, ela aparece do aumento gradual à estabilidade do fluxo e, depois, com outra sequência, passa da baixa tonicidade à retomada brusca da mesma força constante utilizada anteriormente. Achamos preferível simplificar essas variações no quadro seguinte, tomando somente os contrastes entre forte e fraco. Assim, a tabela o possibilita a visualização da variação da tonicidade em relação à 
variação das alturas. Da esquerda para a direita, ela mostra respectivamente cada modo entoativo segundo a avaliação combinatória desses dois parâmetros acústicos.

Dispositivos

\begin{tabular}{l|c|c|c}
\hline \hline \multirow{2}{*}{ Primeiro } & Segundo & Terceiro & Quarto \\
\hline \hline & \multicolumn{3}{|c|}{ Tonicidade } \\
\hline \hline Forte & Forte & Fraco & \multirow{2}{*}{ Forte } \\
\hline \hline & & Tonalidade & \\
\hline \hline \multirow{2}{*}{ Agudo } & Grave & Grave & \multirow{2}{*}{ Agudo }
\end{tabular}

Assim, ao lado da oscilação da tonicidade, a tonalidade aparece seja na forma abreviada seja na alongada. No primeiro e no quarto dispositivos, a elevação do tom coincide com o aumento da energia expiratória. Já no terceiro, o declínio do tom converge para a redução da energia. No segundo modo, o tom grave pontua a tonificação.

A aceleração, por sua vez, não se apresenta como uma característica constante no comportamento vocal desse coro. Seu tipo de aparecimento é apreciado como o de um elemento complementar. Nesse sentido, a variação do andamento é acrescentada aos usos da tonicidade que ganham assim maior destaque e cumprem seu papel de regente dos dispositivos.

\subsubsection{Da segunda encenação (M2)}

A segunda encenação propõe outra entoação para a súplica. A partir dos componentes entoados, quatro dispositivos também podem ser encontrados, incorporando as unidades lexicais de maneira particular. Com isso, esses recortes englobam as unidades conforme as sucessões abaixo. 
1)

Como é que Atenas, a cidade dos rios sagrados, o país que honra seus amigos, poderá acolher a assassina dos próprios filhos?

2)

Com toda força te suplicamos, deixa com vida os pobrezinhos.

3)

Quando as crianças se ajoelharem suplicantes à sua frente, não terás coragem suficiente de manchar as mãos em sangue tão inocente. Ao olhar os olhos dos próprios filhos, não persistirá na impiedosa intenção. Não conseguirás olhá-los e presenciar sem lágrimas tão profundo martírio.

4)

Não pratiques ato tão hediondo em sangue do teu sangue, Medeia.

De maneira geral, a emissão alterna a tonicidade, sem gradação nessa passagem. $\mathrm{Na}$ alternância entre momentos de maior ou menor tonicidade, a aceleração perpassa todas as frases. Além dos aparecimentos da tonicidade e do andamento, os agravamentos recorrentes destacam o terceiro dispositivo no qual as frases iniciadas com um alongamento grave são seguidas pelos suplementos ora da aceleração, ora pela tonificação.

Conquanto a expressão vocal desse coro possa ser definida a partir de sua velocidade constante, a aceleração está presente no terceiro e no quarto modo. Assim, o andamento pode ser esquematizado conforme a aceleração crescente. Além desse aspecto que se revela como recorrente na entoação do coro da segunda encenação de Medeia, os agravamentos são igualmente relevantes na configuração geral de seu comportamento vocal. Com os seus reaparecimentos impregnantes, o tom grave tornase previsível e elemento de sua fisionomia.

A partir disso vemos, conforme segue abaixo, as relações combinatórias entre os parâmetros. Os quatro modos seguem respectivamente da esquerda para a direita na tabela. 
Dispositivos

\begin{tabular}{|c|c|c|c|}
\hline Primeiro & Segundo & Terceiro & Quarto \\
\hline \multicolumn{4}{|c|}{ Tonicidade } \\
\hline Fraca & Forte & Fraca & Forte \\
\hline \multicolumn{4}{|c|}{ Andamento } \\
\hline Regular & Regular & Acelerado & Acelerado \\
\hline \multicolumn{4}{|c|}{ Tonalidade } \\
\hline & & Grave & Agudo \\
\hline
\end{tabular}

\subsection{As diferentes súplicas}

A comparação entre os usos da voz realizados pelos coros evidencia tanto semelhanças quanto diferenças entre eles. Como mencionamos anteriormente, na introdução dessa análise, a principal semelhança entre as encenações é observada no papel da súplica dentro da economia geral das tensões nas tragédias. Como um clímax da peça, há uma intensificação da curva dramática incorporada ao grande consumo de energia expiratória.

Dissemos que a súplica é proferida intensificando um ápice: a somatória de competências da protagonista para completar o ato sanguinário. Em decorrência de um percurso dramático comum, a tonicidade é característica em ambas as encenações, fazendo da súplica a intensidade na previsão do ato funesto. E, desse modo, ao mesmo tempo em que o gesto vocal já carrega intensidade do ato, sua função dramática é a de conter o acontecimento catastrófico e horrendo. 
Acrescentamos a essa semelhança as especificidades construídas em cada coro, extraídas das análises que procuram mostrar como a gestualidade vocal expõe os enunciados verbais. Se há diferenças entre essas construções, elas são percebidas a partir dos posicionamentos desse sujeito enunciativo em cada encenação e das interações que estabelecem sua função. E, conforme os aparecimentos da tonicidade e do andamento, as tensões presentes no plano das sonoridades participam do discurso da encenação. Para que as diferenças dessas posições sejam contempladas, apontamos essas organizações distintas que se inscrevem nessas vozes. Na primeira encenação, o coro usa a tonicidade da emissão de modo variado. Em seu início, o tônus aparece como uma dinâmica crescente, até que ele se estabiliza como uma força constante. No momento subsequente, a tonicidade é abrandada, seguida de súbita retomada da força estável. Já na segunda encenação, a presença do andamento torna-se o elemento recorrente na entoação. Desse modo, pela grande velocidade que ele alcança, esse coro está sujeito a impermanência nas passagens que ele incorpora, em contraponto com a estabilidade sugerida pelo coro da primeira encenação.

O coro de Medeia 2 revela-se não apenas por sua potência acelerada, mas também por seus agravamentos contínuos, igualmente importantes para sua compreensão, pois é facultado à escuta assimilar suas falas nos atrasos propiciados por esses agravamentos. O coro da segunda encenação alonga-se no princípio de cada frase entoada pelo agravamento, realçando o conteúdo trazido na previsão desesperançada. Na relação entre os parâmetros, a duração alongada transforma a aceleração em recuperação do atraso. O agravamento da tonalidade e os atrasos perfazem as fronteiras para o relato do futuro encontro entre Medeia e seus filhos. $\mathrm{O}$ tom sombrio concentra-se nas imagens descritas, para que suas acelerações soem nas terminações, conforme o terceiro momento destacado na análise precedente.

Nesse sentido, o coro da segunda encenação paralisa-se sobre as figuras (mãos em sangue, filhos, lágrimas) e sobre os motivos passionais (coragem, inocência, tristeza), adensando a perplexidade ou o espanto diante do horror. A parada é alongada e, na sua sequencia, o acréscimo de velocidade "diante de ato tão hediondo" irrompe como um gesto desesperado. De outra maneira, o coro da primeira encenação não se concentra sobre essa parte. Pelo contrário, a tonicidade reforça os períodos apelativos 
da súplica procurando obstruir o percurso da protagonista com a interpelação e não com esse relato do futuro. No coro de Medeia 1, com seu movimento na tonicidade, há um pouco de atonização nas imagens das crianças. De certa maneira, refletindo a partir da comparação, essa atonia pode ser tomada como amenização do horror e, em contrapartida, como ascensão da esperança.

$\mathrm{Na}$ medida em que o coro de M2 concentra-se no horror, os alongamentos graves da entoação instauram a espera para a resolução dessa tensão. A contraposição entre o atraso e a aceleração é colocada em relação com o percurso narrativo e passional, indicando o espanto e a fuga subsequente desse grupo. Recobrando-se do medo assombroso, o coro foge na subtaneidade das suas acelerações. Desse modo, na articulação dos diferentes níveis de apreensão, as acelerações estão associadas ao desespero, refletindo parte do movimento catártico dessa encenação. Assim, de um lado, a espera é constituída na paralisia do espanto. De outro, o desespero, "estado de consciência que julga a situação sem saída; desesperançada" (HOUAISS, 2001: 990), torna-se o mote para a construção desse coro.

O coro da primeira encenação pode ser visto como portador de mais esperança. Em decorrência de sua grande tonicidade, a súplica é realizada com extrema veemência, procurando no gesto vocal intenso entrepor-se ao plano de Medeia, mesmo que demonstrando temor. Por isso, verificamos que o espanto seguido de fuga acelerada da segunda encenação não ocorre em Medeia 1.

Para finalizar este breve estudo, retomamos os pontos ditos anteriormente, lançando as hipóteses em relação à projeção da catarse gerada por cada coro. No âmbito geral e do gerenciamento das tensões, a cena da súplica pode ser considerada uma espécie de culminância da encenação, em decorrência tanto da sua expressão sonora, quanto da progressão dramática. No momento de espera e contenção, a súplica é proferida pelo antagonista que, com o seu querer, procura instaurar um dever supremo ou social para impedir o curso da ação da protagonista. Em relação à análise das particularidades dos discursos entoativos, na segunda encenação, o relato do futuro é projetado por um tom sombrio e atrasado, com isso, surge o pathos trágico. $\mathrm{Na}$ análise da primeira encenação, a voz do coro sobredetermina a apelação e, provavelmente, intensifica o dever implicado nessa cena. 
Procuramos compreender a entoação como um discurso, reconhecendo seu funcionamento por meio das suas unidades suprassegmentais e em relação aos enunciados. Em ambas as encenações os coros caracterizam-se pela tonicidade e por suas falas apelativas que atraem a atenção do interlocutor na plateia. Mesmo assim, a descrição procura contemplar suas propriedades particulares. Isto é, na primeira encenação o coro produz suplementos de tonicidade, com sua dinâmica de variação, enquanto na segunda ele é condicionado pela aceleração e pelos agravamentos.

Desse modo, aceitamos que a melodia da fala posiciona o sujeito enunciativo, tornando a encenação um discurso com variadas espessuras e cargas patêmicas. Com essa análise, procuramos esboçar essas camadas a partir da suas cifras tensivas. Por fim, nos papéis assumidos pelos coros, cada construção dessa personagem colabora com o adensamento de determinadas qualidades passionais implicadas o que especifica cada encenação. 


\section{Considerações finais}

Ao descrever os usos da voz do ator teatral, observamos o discurso da entoação por meio da esfera acústica e do que seria específico de uma linguagem cujo plano da expressão é composto por sonoridades, de tal maneira que presumimos tratar em termos gerais de uma semiótica biplanar. Sabemos que a discussão sobre os conteúdos dessa espécie de discurso é mais ampla do que podemos alcançar em nosso breve trajeto de pesquisa e não caberia levantar nesse momento a pertinência de diferentes conjecturas.

Procuraremos sintetizar as reflexões que emergem das análises, para que possamos vislumbrar como esses possíveis conteúdos são estabelecidos nos discursos entoados. Para tanto, ao retomar os questionamentos que surgem a partir da parte empírica de nosso trabalho, dividimos essas considerações finais em três pontos, sendo o primeiro deles atinente ao que se compreende como voz musical e, em seguida, o segundo e o terceiro relativo ao entrecruzamento das qualificações modais e passionais depreendidas por meio dos usos da voz. Dentro dessa segmentação sugerida, as categorias tensivas perpassam as análises de ambos os planos semióticos, do conteúdo e da expressão, tornando-se assim as principais responsáveis pelo procedimento heurístico fundamental deste estudo.

Primeiramente, ao contemplar a musicalidade da fala, é necessário incidir sobre a organização dos sons. De maneira geral, essa organização é sobretudo rítmica, projetada sobre os valores gerados na relação entre os acentos que, por sua vez, está sob o âmbito da temporalidade e em dependência com o andamento. As unidades dos sons parecem definir-se no interior dos processos discursivos, convocando ao menos duas noções para sua composição, a saber, a solidariedade ou a reciprocidade e aquilo que compreendemos como a reconstrução dessas unidades. De um lado, suas durações e intensidades são interdefiníveis por sua reciprocidade nas sucessões temporais. De outro, o ouvido é interpelado ao reconhecimento dessas unidades o que, por fim, 
explicita seus modos de aparecimentos ora como pontuais, ora como globais e dinâmicos. Dito isso, insistimos em expor a necessidade da presença marcada dos procedimentos de análise e, enfim, do questionamento sobre a geração dos valores como, por exemplo, observamos no estudo da rítmica de Medeia 2.

Assim, numa superfície manifestada, as sonoridades suplementam os relevos constituídos de temporalidades. E, no momento em que somos levados à espacializar as sonoridades e as temporalidades, encontrando seus limites ou suas fronteiras e, ainda, suas passagens, os discursos da entoação convocam um fazer da escuta. E, como se um de seus possíveis conteúdos estivesse implicado na dimensão entre a competência e a performance cognitivas, ele nos leva ao fazer crer, saber e, enfim, indagar sobre quais são suas formas e como elas nos tocam ou nos afetam. Essa avaliação está condicionada pela espera da terminação, de modo que a esfera acústica é construída por esses ajustes do que podemos julgar como acabado. Assim, o objeto sonoro transforma-se em objeto do saber, quando contempladas conforme a reflexão zilberbergiana:

(...) não se pode admitir que um texto se desenvolva sem "jogos de saber". Enfim, essa imbricação da espacialização e do saber é de tal ordem que se torna um fato de relevância epistemológica. Na terminologia hjelmsleviana, a abordagem cognitiva aparece claramente como a correspondência, a comunicação de dois espaços: o das formas manifestadas com sua própria lógica e o das substâncias manifestantes, ao qual se acrescenta a formulação das regras de extração dos primeiros a partir dos últimos. (ZILBERBERG, 2006 b: 237)

Entre as sonoridades e seus possíveis conteúdos, convivemos com as pequenas narrativas contadas pelos intervalos que prenunciam a espera e a chegada ao repouso ou, em outros termos, a chegada da reposta. Os valores tímicos e os valores cognitivos são acrescentados aos da narratividade. Assim, quando nos lançamos às dinâmicas das modulações vocais, estamos no mesmo instante tanto na esfera contratual da linguagem quanto na gramática das tensões. 
A partir do momento em que as atividades da cultura humana estão às voltas com a persuasão, as artes problematizam essa esfera, criando uma espécie de contrato em que um dos sujeitos exige o fazer interpretativo do outro, como se o primeiro soubesse que não há exatamente o que dizer sobre uma situação qualquer. No teatro, temos o costume de acreditar que a ambiguidade do discurso é uma qualidade possivelmente glorificante da obra, pois tanto melhor se o teatro não for escrito como um panfleto. O problema teatral está também em o que realmente vale a pena ser dito, como bem sintetiza o drama contemporâneo como na obra, por exemplo, de Samuel Beckett. Quando exalta a incerteza, o fazer teatral faz apelo às vias das percepções sensoriais como uma tentativa de chegada aos possíveis e, desse modo, às muitas compreensões nas aporias necessárias ao conhecimento.

Desse modo, a voz no teatro precipita-se qualificando as modalidades que dispõem o discurso como uma ação em si mesma e, ainda, flexiona ou aspectualiza as paixões que queremos encontrar nas personagens clássicas tal qual a ira de certa Medeia. Em sua relativa autonomia, a proeminência dos conteúdos passionais surge junto às propostas de realizações estéticas, comentando em alguma medida a obra do autor dramático. As personagens encenadas apresentam as leituras e interpretações projetadas pelo trabalho do ator e do encenador.

Suas leituras procuram, sobretudo, estabilizar um eixo para o deslizamento das paixões que mobilizam a ação da personagem na encenação. A audiência atenta coloca-se diante de uma emissão vocal marcada pelo distanciamento de uma espécie de comentário que o ator perfaz durante a encenação. Com a voz, o ator atravessa a máscara e produz uma ressonância percebida como parte da personagem. Com as entoações, a atriz não somente caracteriza Medeia e sua relação com a ação propriamente dita, como também configura as situações específicas em cada encenação.

O trabalho vocal do ator define-se pelas impressões de suposta subjetividade da personagem. Para tanto, as inclinações emocionais são tomadas em sua abrangência, mesmo que apareçam numa versão mais atenuada, como num comportamento ou numa atitude. Contudo, as particularidades dessa ordem estão sempre relacionadas com a ação, uma vez que o drama é ação e, também, embate entre a enunciação de 
uma disposição afetiva e o cumprimento de um deslocamento em cena. Nisso, haveria sempre o conflito entre o que se diz e o que se faz, conflito esse que existe para explicitar ou tangenciar as motivações, ou as intenções, que conduzem os gestos do ator numa difícil missão de objetivação.

Em ambos os engendramentos das protagonistas analisadas, a ira é regente do caráter e, por assim dizer, das deliberações diante das circunstâncias. Mas, diante de suas especificidades, cada uma das personagens encenadas constrói seu campo passional. Os coros encenados manipulam suas vozes em esfera semelhante à encontrada na protagonista, de modo que as qualificações modais e passionais sobredeterminam a esfera pragmática.

Na primeira encenação, o início do percurso narrativo da ira ou da cólera pode ser derivado dos retornos à interrupção da modulação vocal. M1 atualiza seu abandono por Jasão e, com isso, um rompimento, transformando a perplexidade diante desse acontecimento numa atitude particular diante da vingança prometida. Expondo as injustiças sofridas, a entoação dessa construção fortalece a demonstração de seu estado de sujeição e de heteronomia que evoca uma moral ou uma legislação que ela mesma não parece dominar. Em meio aos arroubos que posicionam a personagem em cena, a ação trágica parece decorrer de sua desmedida, a hubris, e da cegueira da razão, a até.

Na segunda encenação, a atuação enfatiza a finalização da paixão, como se M2 já procurasse os meios necessários para o reequilíbrio da sua identidade rompida. A etapa final interna à ira de elaboração da retaliação é mais proeminente, na medida em que a entoação soa no sentido da prossecução ritmada e como maior competência para a execução da vingança. Enquanto há frieza no ardil e razoamento, a personagem assemelha-se ao sujeito que decide, revelando mais autonomia diante da ação que executa.

Na dificuldade do julgamento sobre a entoação que colabora na configuração das personagens, a relação entre paixão e ações ultrapassa a mera oposição, pois a estabilização de uma articulação entre esses níveis de análise traz as motivações da personagem que origina as situações ou se adapta a elas. $\mathrm{O}$ encontro dessa disposição 
do caráter transforma-se em possibilidade de posicionamento afetivo no discurso das personagens analisadas.

Nesse sentido, a teatralidade dialoga com a tensividade, já que a procura dos processos de significação no espaço tensivo também considera a primazia do afeto sobre o mundo inteligível. Isto é, uma análise tensiva traz não somente a possibilidade de uma gramática dos afetos, mas igualmente a necessidade de instaurá-la como pressuposto para a compreensão do sentido.

A comparação entre as encenações possibilita vislumbrar certa independência da afetividade. Na relação entre ação e motivação, a ordem do verossímil sobrepõe-se à ordem do possível e do impossível. Diante dos ajustes entre as diversas ordens internas aos discursos, o julgamento da realidade possível é algo que nem sempre acompanha as necessidades atinentes ao interior da cena, já que até mesmo o absurdo pode ser tratado de maneira lógica, se o seu papel no encadeamento cênico for conveniente. Assim, uma dicção pode ser "incoerentemente coerente", dizia o filósofo grego, ao mostrar a pluralidade de um caráter, personagem ou máscara (ARISTÓTELES, 1973: 456). 


\section{Referências bibliográficas}

ARISTÓTELES Poética. In.: Os Pensadores. Aristóteles. São Paulo: Abril Cultural, 1973.

Retórica das Paixões. São Paulo: Martins Fontes, 2003.

ARTAUD, A. O Teatro e o seu Duplo. São Paulo: Martins Fontes, 1999.

BAILLY, A. Le Grand Bailly Dictionnaire Grec - Français. Paris: Hachette, 2000.

BARTHES, R. Oeuvres Complètes. Tome I. Paris: Seuil, 1993.

BERTRAND, D. Caminhos da Semiótica Literária. Bauru: EDUSC, 2003.

CARLSON, M. Teorias do Teatro. São Paulo: UNESP, 1995.

DERRIDA, J. A Escritura e a Diferença. São Paulo: Perspectiva, 2005.

DIDEROT. A Filosofia de Diderot. Seleção de textos. São Paulo: Cultrix, 1966.

DORT, B. La Représentation Émancipée. Paris: Actes Sud, 1988.

EURIPIDES. Medeia. Rio de Janeiro: Civilização Brasileira, 1972.

FÉRAL, J. “ Performance et théâtralité: le sujet démystifié”. In.: Théâtralité, Écriture et Mise en Scène. Québec: Hurtubise, 1985; pp. 125 - 139.

. "Qué puede (o quiere) la teoria del teatro ?". In.: Revue Theatro XXI,

Buenos Aires, Ano VI, n 11, Primavera, pp. 10-18. Tradução do artigo: "Que peut (ou veut) la théorie du théâtre ? " paru dans L'Annuaire théâtral, no 29, 2001; pp.28-50.

."La théâtralité. Recherche sur la spécificité du langage théâtral". In.: Poétique 75, septembre 1988; pp.347 - 361 .

FIORIN, J. L. Elementos de Análise do Discurso. São Paulo: Contexto, 2008.

FONTANILlE, J. e ZILBERBERG, C. Tensão e Significação. São Paulo: Discurso Editorial: Humanistas, 2001.

GREIMAS, A-J. Semântica Estrutural. São Paulo: Cultrix, 1973. 
. "De la colère. Étude de sémantique lexicale". In.: Du Sens II. Essais Sémiotiques. Paris: Seuil, 1983, pp. 225 -246.

e COURTÉS, J. Dicionário de Semiótica. São Paulo: Contexto, 2008. e FONTANILLE, J. Semiótica das Paixões. São Paulo: Ática, 1993.

. Sémiotique des Passions. Des Etats de Choses aux Etats d'âme. Paris: Seuil, 1991.

GUIMARÃES, R. Dicionário de Mitologia Grega. São Paulo: Cultrix, 1995.

HELBO, A. Les Mots et les Gestes. Lille: Presse Universitaire de Lille, 1983.

HJELMSLEV, L. Ensaios Linguísticos. São Paulo: Perspectiva, 1991. . Nouveaux Essais. Paris: PUF, 1985.

HOUAISS, A. e VILLAR, M. Dicionário Houaiss de Língua Portuguesa. Rio de Janeiro: Objetiva, 2001.

LEON, P. Précis de Phonostylistique: Parole et Expressivité. Paris: Nathan, 1993.

LYOTARD, J-F. Des Dispositifs Pulsionnels. Paris: Galilée, 1994.

MAGALDI, S. O Texto no Teatro. São Paulo: Perspectiva, 2008.

MILARÉ, S. Antunes Filho e a Dimensão Utópica. São Paulo: Perspectiva, 2007.

PARRET, H. La Voix et Son Temps. Bruxelles: De Boeck, 2002.

PAVIS, P. "La théâtralité en Avignon”. In.: Vers une Théorie de la Pratique Théâtrale. Paris: Presses Universitaires du Septentrion, 2000; pp. 317 - 337.

. Dicionário de Teatro. São Paulo: Perspectiva, 2005.

QUÉRÉ, H. «La voix est-elle saisissable? » In.: BADIR, S. e PARRET, H. (dir.) Puissances de la Voix. Corps Sentant, Corde Sensible. Limoges: Pulim, 2001; pp. 13 24

RANCIÈRE, J. A Partilha do Sensível. São Paulo: Editora 34, 2009.

ROSSI, M. L'intonation. De l'acoustique a la sémantique. Paris: Klincksieck, 1981. 
SARRAZAC, J-P. "L'invention de la théâtralité." In.: Critique du Théâtre. De l'utopie au désenchantemente. Paris: Circé, 2000; pp. $53-71$.

SAUSSURE, F. Curso de Linguística Geral. São Paulo: Cultrix, 2006.

SOURIAU, E. As Duzentas Mil Situações Dramáticas. São Paulo: Ática, 1993.

STANISLAVISKY, C. A Criação do Papel. Rio de Janeiro: Civilização Brasileira, 1984.

TATIT, L. Musicando a Semiótica: Ensaios. São Paulo: Annablume, 1997.

. O Cancionista: Composição de Canções no Brasil. São Paulo: EDUSP, 1996.

UBERSFELD, A. Para Ler o Teatro. São Paulo: Perspectiva, 2005.

VERNANT, J-P., VIDAL-NAQUET, P. Mito e Tragédia na Grécia Antiga. São Paulo: Perspectiva, 1999.

ZILBERBERG, C. Éléments de Grammaire Tensive. Limoges: Pulim, 2006 a. . Razão e Poética do Sentido. São Paulo: EDUSP, 2006 b.

. "Signification du rythme et rythme de la signification". In.: Degrès, no 87, automne 1996; pp. a-25a.

. "Remarques sur l'assiette tensive du rythme." In.: (?) : 2001; pp. 1 - 28. 